\title{
‡USGS
}

science for a changing world

Prepared in cooperation with Oregon Water Resources Department

\section{Origin, Extent, and Thickness of Ouaternary Geologic Units in the Willamette Valley, Oregon}

\section{Professional Paper 1620}

U.S. Department of the Interior U.S. Geological Survey 


\section{Cover photographs}

Front cover: Late Quaternary fluvial gravel about 20 meters below the ground surface, at the Delta Sand and Gravel Quarry, near Eugene, Oregon. (Photograph by Terrence D. Conlon, U.S. Geological Survey.)

Back cover: Sequence of Pleistocene deposits exposed along the Willamette River near Monmouth, Oregon. (Photograph by Jim E. O'connor, U.S. Geological Survey.) 


\section{Origin, Extent, and Thickness of Quaternary Geologic Units in the Willamette Valley, Oregon}

By JIM E. O'CONNOR, ANDREI SARNA-WOJCICKI, KARL C. WOZNIAK, DANIAL J. POLETTE, AND ROBERT J. FLECK

Prepared in cooperation with

Oregon Water Resources Department

U.S. Geological Survey Professional Paper 1620 


\section{U.S. DEPARTMENT OF THE INTERIOR GALE A. NORTON, Secretary}

U.S. GEOLOGICAL SURVEY

CHARLES G. GROAT, Director

Any use of trade, product, or firm names in this publication is for descriptive purposes only and does not imply endorsement by the U.S. Government.

For sale by the

U.S. Geological Survey

Information Services

Box 25286

Federal Center

Denver, CO 80225

Library of Congress Cataloging in Publication Data

Origin, extent, and thickness of Quaternary geologic units in the Willamette Valley, Oregon / by Jim E. O'Connor ... [et al.]. ; prepared in cooperation with Oregon Water Resources Department.

p. cm. -- (U.S. Geological Survey professional paper; 1620)

Includes bibliographical references.

ISBN 0-607-94832-9

1. Geology, Stratigraphic--Quaternary. 2. Geology--Oregon--Willamette River Valley. I. O'Connor, Jim E., 1959- II. Oregon. Water Resources Dept. III. Series. 


\section{CONTENTS}

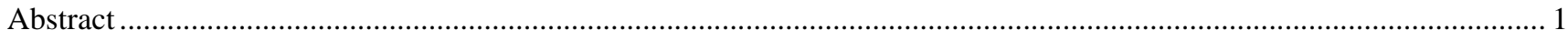

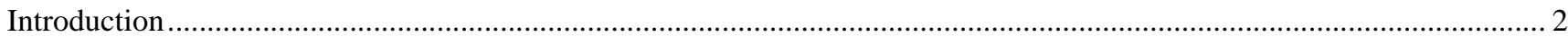

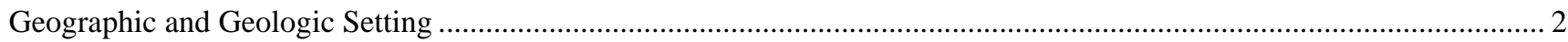

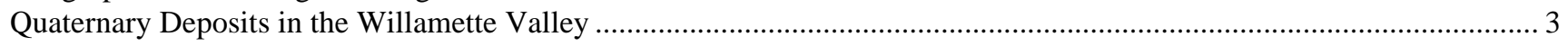

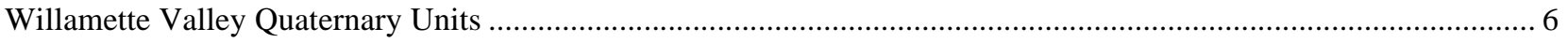

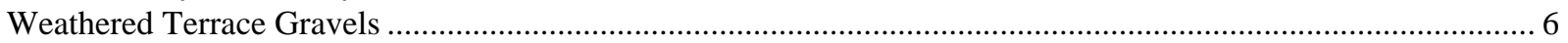

Pleistocene Sand and Gravel of the Willamette River and Major Cascade Range Tributaries ............................. 9

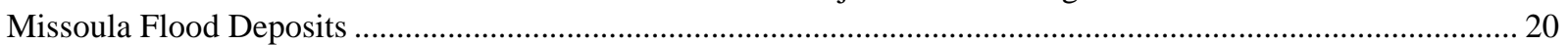

Holocene Floodplain Deposits of the Willamette River and Major Tributaries.................................................. 26

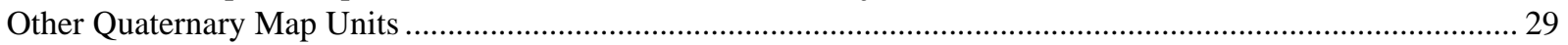

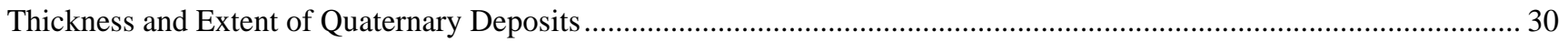

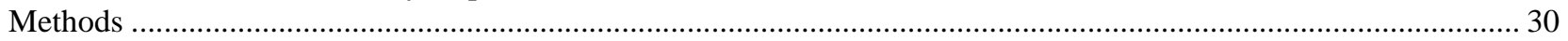

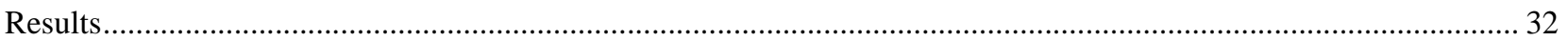

Thickness of Sand and Gravel Facies of Holocene Floodplain Deposits ...................................................... 32

Thickness of Pleistocene Sand and Gravel that Postdates the Missoula Floods .............................................. 32

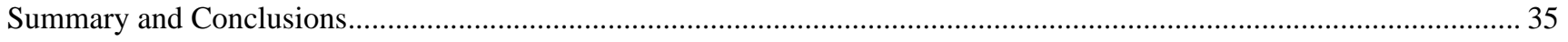

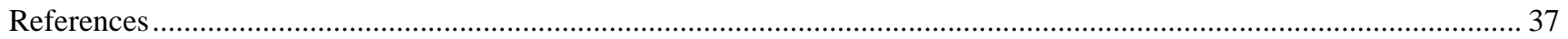

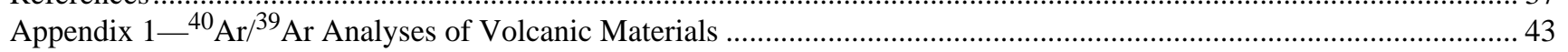

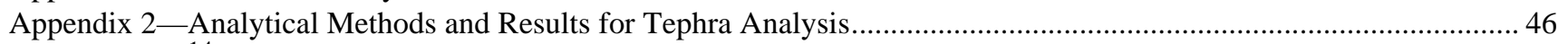

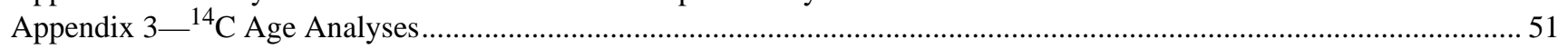

\section{PLATE}

1. Geologic Map of Quaternary Units in the Willamette Valley, Oregon

\section{FIGURES}

1. Correlation chart showing history of stratigraphic frameworks developed for the Willamette Valley, including formal and informal nomenclature, assigned ages, and inferred deposit genesis ................................ 4

2. Correlation chart showing relations between Quaternary geologic units identified in this study and those identified in the Regional Aquifer System Analysis by Gannett and Caldwell (1998) ............................... 6

3. Generalized geologic sections showing relations of Quaternary geologic units in the study area ....................... 7

4. Profile of Willamette and Middle Fork Willamette Rivers showing positions of surfaces of weathered terrace gravels and subsurface bedrock beneath the Holocene floodplain.......................................................... 8

5. Profile of Willamette and Middle Fork Willamette Rivers showing tops of Pleistocene sand and gravel deposits and the base of the latest Pleistocene (about $12 \mathrm{ka}$ ) deposits .......................................... 11

6. Generalized stratigraphic diagrams and chronologic information for sections of late Quaternary stratigraphy exposed in deep gravel pits in the Willamette Valley ...................................................................... 12

7. Photograph of Pleistocene sand and gravel exposed at Walling Sand and Gravel pit near Turner Gap ............... 14

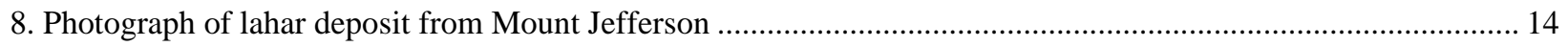

9. Photograph and geologic interpretation of Pleistocene deposits exposed on the east bank of the Willamette River at river mile 102.5 near Sidney.....

10. Correlation of stratigraphic sections measured from exposures along the Willamette River showing locations of tephra and radiocarbon samples, and the nature of contact between the main body of Missoula Flood deposits and the Pleistocene sand and gravel that predates the Missoula Flood deposits................................... 17

11. Profile of Willamette River showing altitudes and thickness of fine-grained Missoula Flood deposits ................ 21

12. Profile of Willamette and Middle Fork Willamette Rivers showing positions of Holocene floodplain surfaces, the base of Holocene deposits, and bedrock beneath Holocene deposits.

13. Photograph, schematic representation of a measured stratigraphic section, and Holocene fluvial deposits exposed along the Willamette River at the southern end of Bear Island (river mile 140) .......

14. Approximate thickness of the sand and gravel (channel) facies of Holocene floodplain deposits

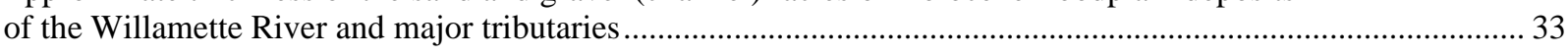

15. Approximate thickness of the Pleistocene sand and gravel that postdates the Missoula Floods............................ 34 
CONVERSION FACTORS, VERTICAL DATUM

\begin{tabular}{rll}
\hline Multiply & By & To obtain \\
\hline centimeter $(\mathrm{cm})$ & 0.3937 & inch \\
millimeter $(\mathrm{mm})$ & 0.03937 & inch \\
meter $(\mathrm{m})$ & 3.281 & foot \\
kilometer $(\mathrm{km})$ & 0.6214 & mile \\
meter $(\mathrm{m})$ & 1.094 & yard \\
square kilometer $\left(\mathrm{km}^{2}\right)$ & 247.1 & acre \\
\hline
\end{tabular}

Sea level: In this report "sea level" refers to the National Geodetic Vertical Datum of 1929 (NGVD of 1929) - a geodetic datum derived from a general adjustment of the first-order level nets of both the United States and Canada, formerly called Sea Level Datum of 1929. 


\title{
Origin, Extent, and Thickness of Quaternary Geologic Units in the Willamette Valley, Oregon
}

\author{
ByJim E. O'Connor, Andrei Sarna-Wojcicki, Karl C. Wozniak, Danial J. Polette, and \\ Robert J. Fleck
}

\section{Abstract}

Stratigraphic and chronologic information collected for Quaternary deposits in the Willamette Valley, Oregon, provides a revised stratigraphic framework that serves as a basis for a 1:250,000-scale map, as well as for thickness estimates of widespread Quaternary geologic units. We have mapped 11 separate Quaternary units that are differentiated on the basis of stratigraphic, topographic, pedogenic, and hydrogeologic properties. In summation, these units reflect four distinct episodes in the Quaternary geologic development of the Willamette Valley:

1. Fluvial sands and gravels that underlie terraces flanking lowland margins and tributary valleys were probably deposited between 2.5 and 0.5 million years ago. They are the oldest widespread surficial Quaternary deposits in the valley. Their present positions and preservation are undoubtedly due to postdepositional tectonic deformation - either by direct tectonic uplift of valley margins, or by regional tectonic controls on local base level.

2. Tertiary and Quaternary excavation or tectonic lowering of the Willamette Valley accommodated as much as $500 \mathrm{~m}$ (meters) of lacustrine and fluvial fill. Beneath the lowland floor, much of the upper 10 to 50 $\mathrm{m}$ of fill is Quaternary sand and gravel deposited by braided channel systems in subhorizontal sheets 2 to $10 \mathrm{~m}$ thick.

These deposits grade to gravel fans 40 to 100 m thick where major Cascade Range rivers enter the valley and are traced farther upstream as much thinner valley trains of coarse gravel. The sand and gravel deposits have ages that range from greater than 420,000 to about 12,000 years old. A widely distributed layer of sand and gravel deposited at about $12 \mathrm{ka}$ (kiloannum, thousands of years before the present) is looser and probably more permeable than older sand and gravel. Stratigraphic exposures and drillers' logs indicate that this late Pleistocene unit is mostly between 5 and $20 \mathrm{~m}$ thick where it has not been subsequently eroded by the Willamette River and its major tributaries.

3. Between 15,000 and 12,700 years ago, dozens of floods from Glacial Lake Missoula flowed up the Willamette Valley from the Columbia River, depositing up to $35 \mathrm{~m}$ of gravel, sand, silt, and clay.

4. Subsequent to 12,000 years ago, Willamette River sediment and flow regimes changed significantly: the Pleistocene braided river systems that had formed vast plains of sand and gravel evolved to incised and meandering rivers that are constructing today's fine-grained floodplains and gravelly channel deposits. Sub- 
surface channel facies of this unit are loose and unconsolidated and are highly permeable zones of substantial groundwater flow that is likely to be well connected to surface flow in the Willamette River and major tributaries. Stratigraphic exposures and drillers' logs indicate that this unit is mostly between 5 and $15 \mathrm{~m}$ thick.

\section{INTRODUCTION}

Sedimentary units of Quaternary age are widely distributed throughout the Willamette Valley of western Oregon. These deposits host the soils that support much of the region's agricultural production; are important ground-water sources for domestic, agricultural, and municipal uses; and serve as building sites and construction materials for the rapidly growing communities of Eugene, Springfield, Corvallis, Albany, Salem, Newberg, and Wilsonville. These sediments also record varied Quaternary depositional environments and events resulting from a variety of tectonic, volcanic, and climatic influences. Understanding the origin, nature, distribution, and thickness of surficial geologic units provides glimpses of past geologic environments as well as information that can guide future development and resource use in the Willamette Valley. The study area (pl. 1) includes the large basins of the northern and southern Willamette Valley between Oregon City and Eugene, and parts of valleys of the major Cascade Range tributaries. In total, the mapped area is about $5,000 \mathrm{~km}^{2}$ (square kilometers).

The purpose of this mapping was to define the extent and thickness of major deposits of Quaternary age to support numerical modeling of the regional ground-water system within the Willamette River Basin. This work was funded cooperatively by the U.S. Geological Survey (USGS) and Oregon Water Resources Department as part of the Willamette Ground-Water Study.

Fieldwork was conducted during 1996-97 and was primarily directed towards defining a regional framework of Quaternary deposits. This framework was developed from widely scattered exposures in conjunction with radiometric age dating and tephrochronology. A regionally consistent geologic map of
Quaternary deposits was produced by using this stratigraphic framework to interpret existing topographic, geologic, and National Resource Conservation Service (NRCS, formerly Soil Conservation Service) soils maps. Supplemental information on unit thicknesses, subsurface extent, and general facies relationships was obtained from inspection of more than 800 drillers' $\operatorname{logs}$ for water wells, oil-test wells, and geotechnical borings from the collection of State of Oregon Water Well Reports maintained in the USGS Oregon District office in Portland, Oregon. Many of these wells are included in the Willamette Ground-Water Study database of field-located wells (Orzol and others, 2000).

Our understanding of the Quaternary geology of the Willamette Valley was aided by discussions with Marshall Gannett, Rodney Caldwell, Terrence Conlon, Leonard Orzol, William McFarland, David Morgan, William Scott, Richard Waitt, Ray Wells, Silvio Pezzopane (all U.S. Geological Survey); John Beaulieu, Tom Wiley, Ian Madin (Oregon Department of Geology and Mineral Industries); Patricia McDowell (University of Oregon); Peter Clark (Oregon State University; Frank Reckendorf (consultant); Scott Burns, Marvin Beeson, and Terry Tolan (Portland State University). Tana L. Haluska (U.S. Geological Survey) helped construct the thickness maps. The map and report were reviewed by Terrence Conlon, William Scott, William McFarland, Marshall Gannett, Ian Madin, and John Beaulieu.

\section{GEOGRAPHIC AND GEOLOGIC SETTING}

The Willamette Valley is a broad alluvial plain in northwestern Oregon flanked on the west by early Tertiary marine sedimentary and volcanic rocks of the Coast Range, and on the east by Tertiary and Quaternary volcanic and volcaniclastic rocks of the Cascade Range. Tributaries that drain these ranges join the Willamette River along its $300 \mathrm{~km}$ (kilometer) northward course from its inception at the confluence of the Coast and Middle Forks near Eugene, to north of Portland where the Willamette River enters the Columbia River. Within the map area, the Willamette River meanders through an extensive lowland (terrain of low relief typically below altitudes of $100-150 \mathrm{~m}$ above sea level) that is typically 30 to $50 \mathrm{~km}$ wide, but is locally much narrower where the river has cut gaps through transverse uplands (foothills and portions of 
the Cascade and Coast Ranges with altitudes greater than 100-150 m). Outside of the main Willamette Valley, the valley floors of the major Coast Range and Cascade Range tributaries are typically less than $3 \mathrm{~km}$ wide.

The Willamette Valley has been a topographic low for at least 15 million years. The distribution and thickness of middle Miocene flood basalts of the Columbia River Basalt Group (CRBG) indicate that by about $15 \mathrm{Ma}^{1}$ (mega-annum; millions of years before present), a broad lowland existed in the present location of the northern Willamette Valley (Gannett and Caldwell, 1998). Subsequent uplift of the Coast and Cascade Ranges has further defined the basin of the Willamette Valley along the north-south axis of a regional synclinorium and has resulted in continued filling of the lowlands with sediment from the flanking mountain ranges (Yeats and others, 1996). Structural deformation, including subbasin subsidence and faulting, has created uplands of Columbia River Basalt Group rocks across this synclinorium between Albany and Salem that separate the northern Willamette Valley from the southern Willamette Valley, as well as bounding the Stayton subbasin southeast of Salem (Crenna and others, 1994). Faulting and PliocenePleistocene basalt flows form uplands near Oregon City that separate the Portland Basin from the northern Willamette Valley (Beeson and others, 1989; Madin, 1990, 1994). Sherrod and Pickthorn (1989) suggested that the southern Willamette Valley is primarily a strike valley formed by preferential excavation of softer geologic units, whereas the northern Willamette Valley and Stayton subbasin are primarily tectonic depressions (Yeats and others, 1996). Gannett and Caldwell (1998) and Yeats and others (1996) provide more detailed summaries of the pre-Quaternary geologic history and structural evolution of the Willamette Valley and the flanking mountain ranges.

The basins of the Willamette Valley and tributary valleys have accumulated up to $500 \mathrm{~m}$ of Neogene and Quaternary fill from the surrounding uplands and the Columbia River Basin. This alluvial fill contains the vast majority of the ground water used in the Willamette Valley. The valley and basin sediments range from fine-grained Miocene(?) and Pliocene fluviallacustrine deposits near the basin bottoms to Quaternary-age sediment in the upper 0 to $100 \mathrm{~m}$ that are pri-

\footnotetext{
1"Ma" refers to millions of years before present, and in this report is used to indicate radiometric and fission track ages on volcanic rocks.
}

marily coarse-grained fluvial deposits derived from the Cascade Range and Missoula Flood sediment from the Columbia River Basin (Gannett and Caldwell, 1998). This report focuses on the extent, chronology, and thickness of the near-surface deposits that are mostly of Quaternary age.

\section{QUATERNARY DEPOSITS IN THE WILLAMETTE VALLEY}

For more than 100 years, geologists, geomorphologists, and soil scientists have investigated late Tertiary and Quaternary deposits in the Willamette Valley. These efforts resulted in a variety of local and regional maps of landforms (Balster and Parsons, 1968), surficial geology (for example, Piper, 1942; Allison, 1953; Allison and Felts, 1956; Glenn, 1965; Beaulieu and others, 1974; Bela, 1979, 1981; Gannett and Caldwell, 1998), and soils (Williams, 1972; Otte and others, 1974; Knezevich, 1975, 1982; Gerig, 1985; Langridge, 1987; Patching, 1987). This work, as well as more local stratigraphic studies (for example, Balster and Parsons, 1969; Roberts, 1984), have led to a variety of conceptual models of the chronology, stratigraphic relations, and depositional environments of Quaternary deposits within the Willamette Valley (fig. 1). Glenn (1965, p. 11-28), and more recently McDowell (1991), thoroughly summarized much of this work in addition to pointing out many stratigraphic and chronologic problems and inconsistencies with then-current models of the Quaternary geology of the Willamette Valley. Many of these problems can be ascribed to two factors: (1) the paucity of chronologic control and (2) misapplication of broad conceptual models of landscape development and Quaternary stratigraphy. The latter factor was especially important in development of hypotheses regarding the stratigraphic relations, chronology, and genesis of deposits left by the Missoula Floods.

For this study, the stratigraphic framework of Quaternary deposits was updated by (1) direct examination of field exposures, (2) new chronologic information, and (3) incorporating results of recent studies of Quaternary geology elsewhere in the Pacific Northwest. Deep gravel pits and riverbanks provide many exposures of Quaternary stratigraphy throughout the Willamette Valley. Tephra correlations and radiometric dating of organic and volcanic materials contained in many exposures substantially increase chronologic 


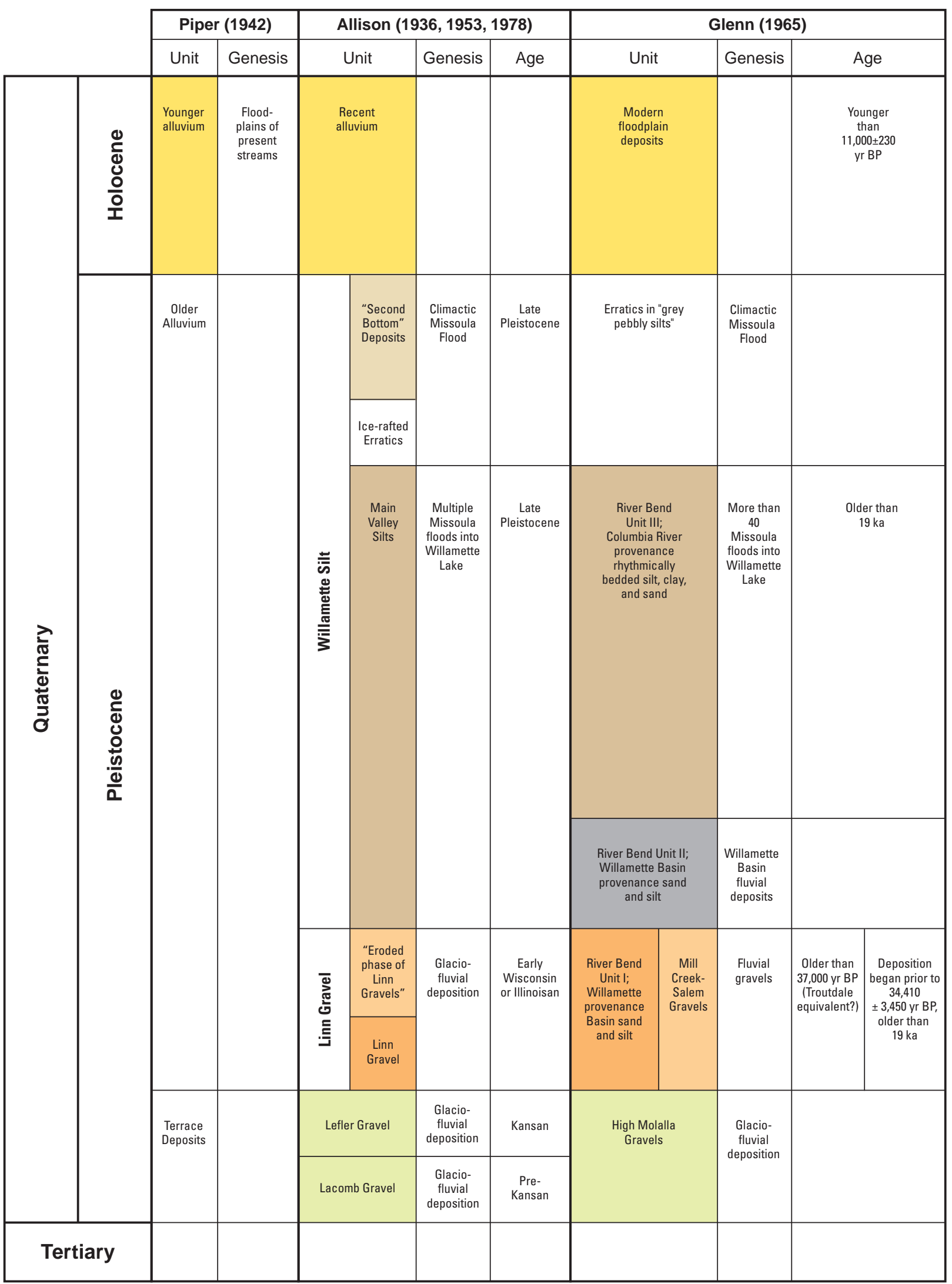

Figure 1. History of stratigraphic frameworks developed for the Willamette Valley, including formal and informal units. Reckendorf [1993] provided an alternative interpretation of ages and formative processes for the stratigraphic 


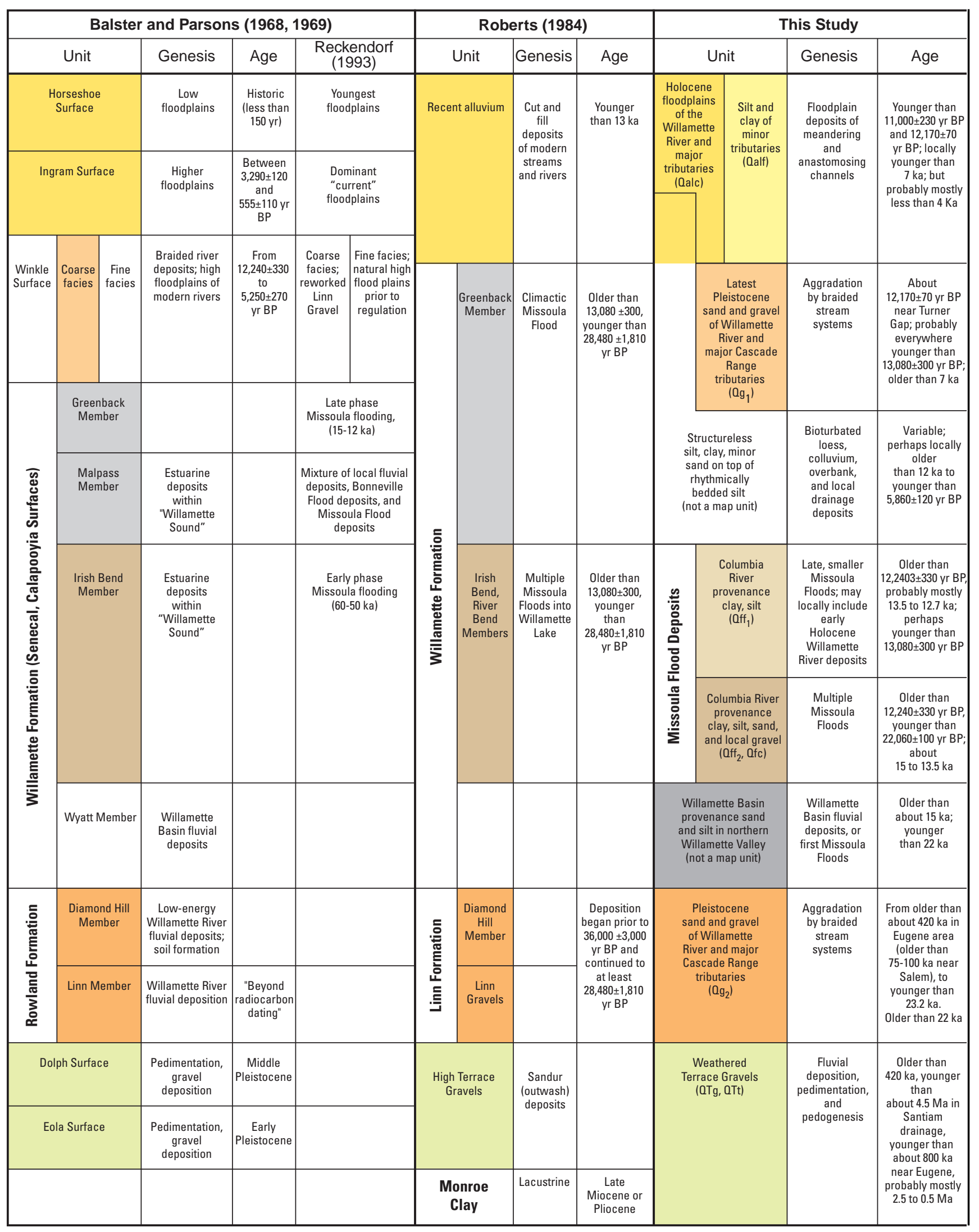

nomenclature, assigned ages, and inferred deposit genesis. (Colors indicate correlations between individual stratigraphic framework developed by Balster and Parsons [1968, 1969].) 
information for these deposits. These stratigraphic and chronologic relations, aided by consideration of deposit characteristics, surface morphology, and current understanding of regional Quaternary environments, lead to the stratigraphic framework proposed in this report. This framework is general and is based on reconnaissance-level correlations, thus it is sure to be modified as more detailed studies are conducted and regional understanding of Quaternary events evolves. Nevertheless, this stratigraphic framework provides a regionally consistent basis for mapping the surficial geology shown on plate 1 and for estimating thicknesses of hydrogeologically significant Quaternary units. The relation of Quaternary stratigraphic units identified in this report to those of previous studies is shown in figure 1; the relation to the hydrogeologic units defined by Gannett and Caldwell (1998) is shown in figure 2.

Many Quaternary stratigraphic units in the Willamette Valley have been assigned a variety of formal and informal lithostratigraphic names by past workers (fig. 1), now making it difficult to use formal stratigraphic names on a regional basis. Consequently, we have generally not used such names in favor of descriptive unit names. Nevertheless, formal and informal names are referred to in the following unit descriptions to aid comparison with previous studies and nomenclature.

\section{Willamette Valley Quaternary Units}

\section{Weathered Terrace Gravels (QTg)}

Weathered fluvial gravels and associated pediment surfaces locally flank the main valley floors. The main localities are where they underlie a series of broad piedmonts along the eastern margin of the northern Willamette Valley between Molalla and Silverton, low terraces along the western margin of the southern Willamette Valley between Corvallis and Eugene, scattered terrace remnants on uplands that cross the main axis of the valley, and high terraces and fan remnants above the valley floor along most of the major Cascade Range tributaries (fig. 3). They wholly or partly include the terrace deposits of Piper (1942), the Leffler and Lacomb gravels of Allison (1936, 1953), the decomposed sediment of Baldwin and others (1955), the Quaternary higher terrace deposits of Bela (1979), and the upper and middle terraces of Beaulieu

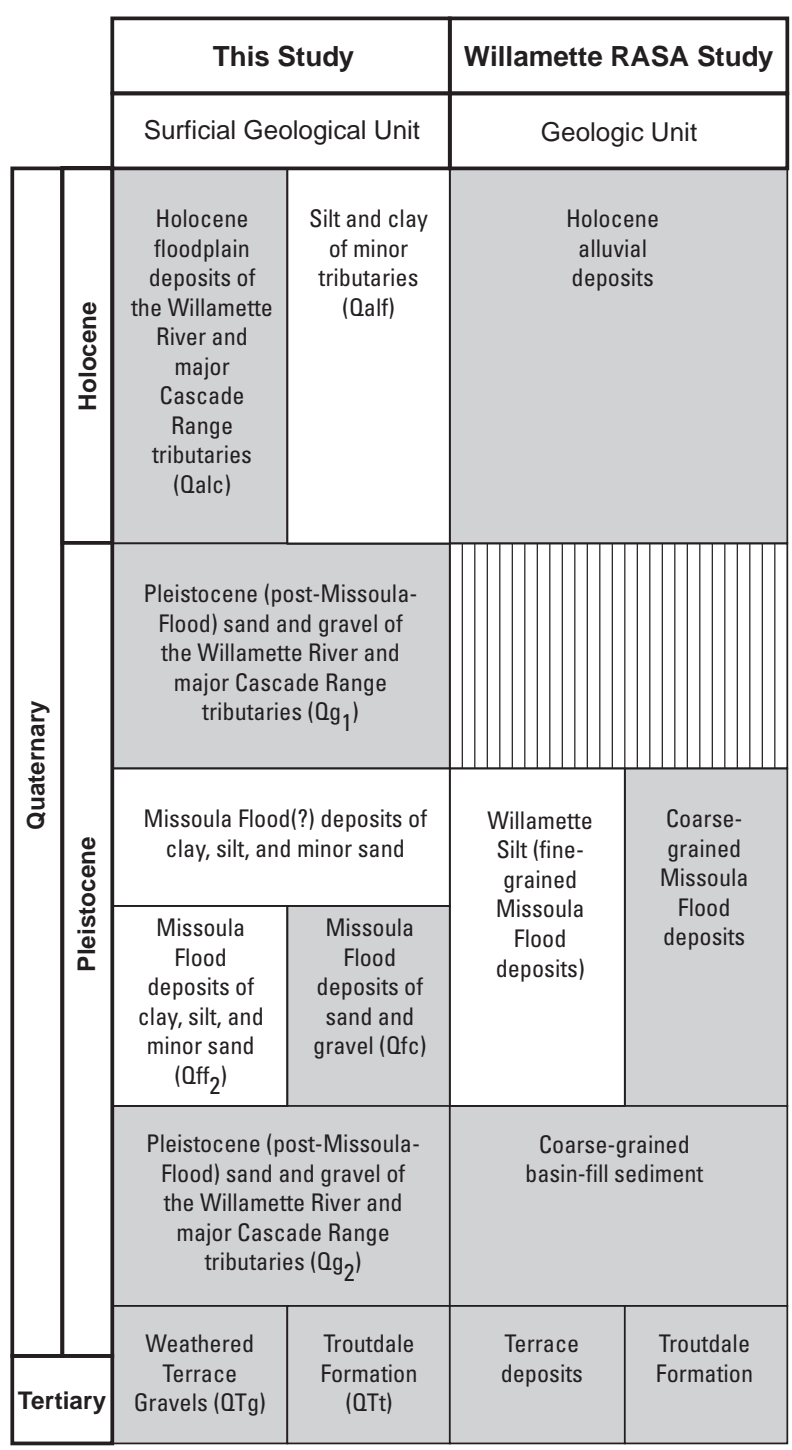

Figure 2. Relations between Quaternary geologic units identified in this study and those identified in the Regional Aquifer System Analysis (RASA) by Gannett and Caldwell (1998). (Shaded areas indicate units that are components of the Willamette Aquifer hydrogeologic unit of Gannett and Caldwell [1998] within the Willamette lowland.)

and others (1974). Where similar deposits have been mapped as Troutdale Formation near Molalla (Trimble, 1963; Hampton, 1972), we have retained that designation (mapped as unit QTt), although there is no clear distinction between deposits mapped as Troutdale Formation and the weathered terrace gravels that underlie piedmont surfaces to the immediate southwest. The Quad, Dolph, and Eola geomorphic surfaces of Balster and Parsons (1968) partly correspond to the distribution of weathered terrace gravels and nearby pediments. 

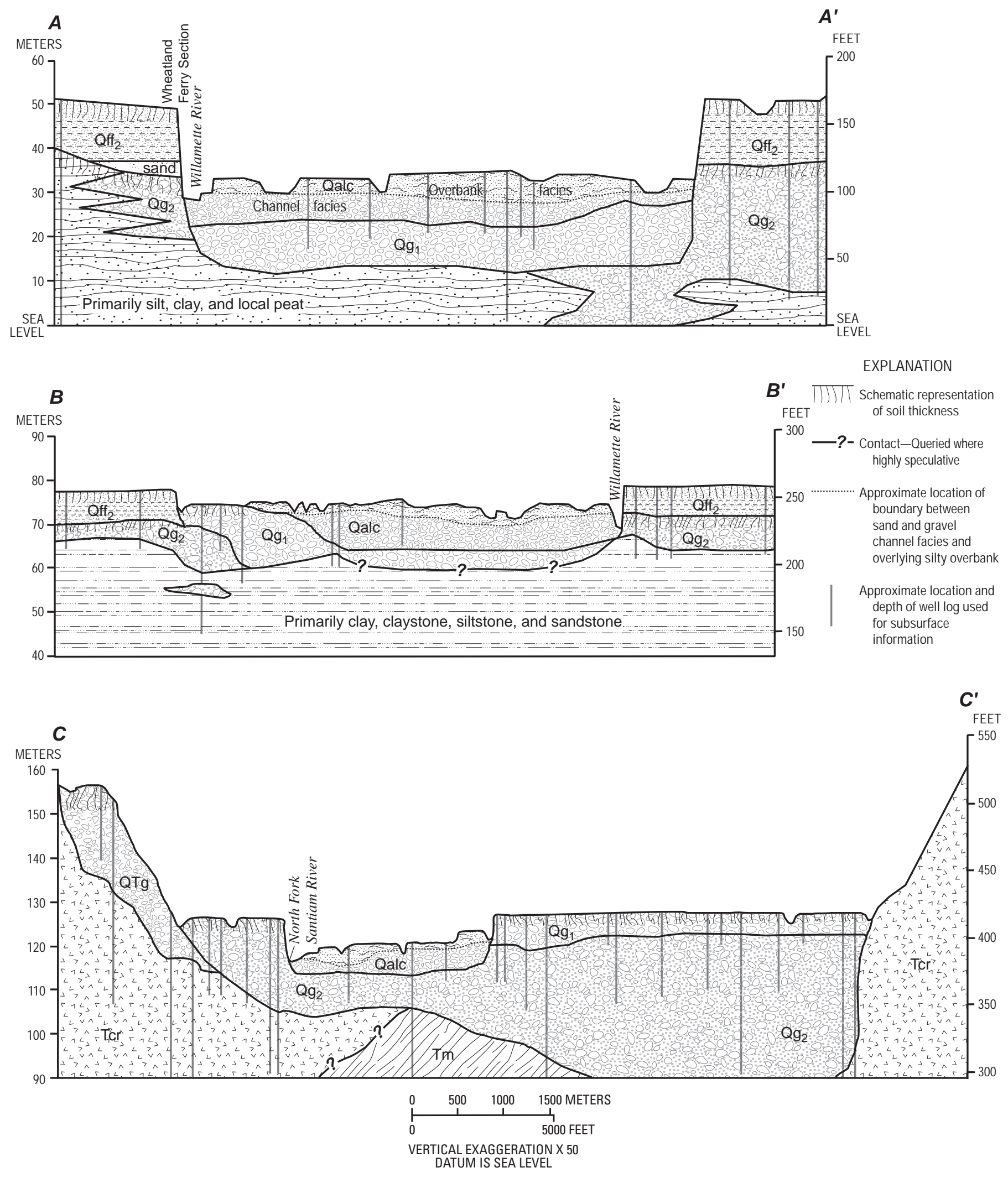

Figure 3. Relations of Quaternary geologic units in the study area. (Subsurface geology on basis of stratigraphic exposures and drillers' logs [approximate positions and depths indicated]. The section traces are shown on plate 1.

$\boldsymbol{A}-\boldsymbol{A}^{\prime}$, Northern Willamette Valley; $\boldsymbol{B}-\boldsymbol{B}^{\prime}$, Southern Willamette Valley; $\boldsymbol{C}-\boldsymbol{C}^{\prime}$, Stayton subbasin.) 
Geomorphology, Stratigraphy, and Mapping Criteria.-Terrace and pediment treads have heights ranging from 5 to more than $100 \mathrm{~m}$ above present river levels, and locally have multiple distinct levels (fig. 4). The thickness of underlying sand and gravel varies; commonly it is only a few meters thick or less, especially along the Willamette Valley where such surfaces on unit QTg have been locally mapped as pediments (Bela, 1979; Roberts, 1984). But elsewhere, drillers' logs indicate extensive areas of much thicker sand and gravel. The greatest known thicknesses are the 75 to $150 \mathrm{~m}$ of so-called Troutdale Formation sand and gravel southwest of Molalla (Hampton, 1972), 30 to $60 \mathrm{~m}$ of sand and gravel near Corvallis and Philomath (Bela, 1979), 30 to $60 \mathrm{~m}$ of sand and gravel southeast of Eugene, greater than $35 \mathrm{~m}$ beneath high terraces along the North Fork Santiam River near Lyons, and 20 to $30 \mathrm{~m}$ thick sand and gravel beneath terraces south of Stayton (fig. 3, geologic section C-C').

The distinctive characteristic of these deposits is the substantial weathering and pedogenic alteration of their uppermost several meters. Soils on the weathered terrace gravels are typically classified as Xeric Haplohumults or Ultic Haploxeralfs, indicating that there has been extensive leaching of mobile elements. The upper few meters of these red and clay-rich soils commonly enclose ghosts of pebbles and cobbles that are readily sliced by shovel or knife. Large clasts at greater depths within the weathered zone have weathering rinds that almost always exceed $5 \mathrm{~mm}$ (millimeters), and are typically 1 to $5 \mathrm{~cm}$ (centimeters) where unweathered cores can be found. Some exposures show horizons cemented by iron or manganese oxides. Few sedimentary features are visible, but isolated small exposures show that this unit is generally composed of subhorizontal beds of rounded gravel clasts in a sand and silt matrix.

Unit QTg was mapped primarily on the basis of previous geologic mapping, largely following Piper (1942), Allison (1953), Allison and Felts (1956), Hampton (1972), and Bela (1979, 1981). Placement of contacts on 1:24,000 maps and modifications from previous geologic maps was based on topography and mapped soils. Common and typically diagnostic soils shown in Soil Conservation Service (SCS, now Natural Resources Conservation Service) maps are the Nekia, Salkum, Veneta, and Jory series.

Age.-There are few age constraints on the weathered terrace gravels. Allison (1936) and later workers (for example, Beaulieu and others, 1974; Roberts,

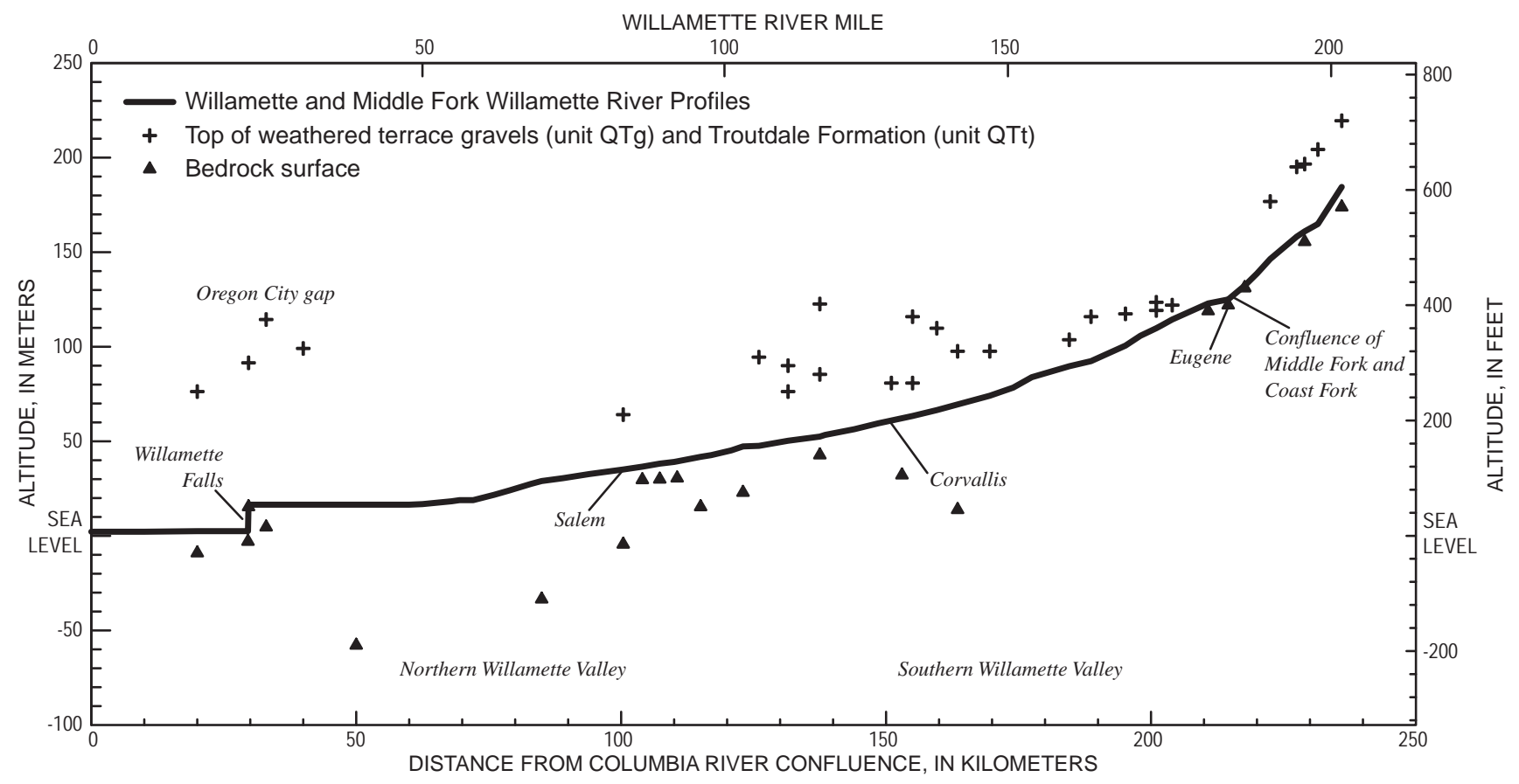

Figure 4. Positions of surfaces of weathered terrace gravels (including Troutdale Formation surfaces near Oregon City gap) and subsurface bedrock beneath the Holocene floodplain. (Terrace altitudes from U.S. Geological Survey topographic quadrangles. Data for approximate bedrock altitudes under present river course were derived from drillers' logs and channel exposures. Distance from the Columbia River confluence ["valley kilometer"] was measured along the general trend of the modern floodplain and does not directly correspond to river miles [see plate 1 for distance indicators].) 
1984) have speculated, on the basis of the intense weathering, that this unit was deposited in the Early to Middle Pleistocene. In the valley of the South Fork of the Santiam River, high terraces formed of these deposits must be younger than a $4.5 \pm 0.3 \mathrm{Ma}$ basalt flow that caps Marks Ridge near Sweet Home (Verplanck, 1985, cited in Walker and Duncan, 1989). Other ridge-capping basalts in the Santiam River drainage are as young as $2.8 \pm 0.3 \mathrm{Ma}$ (Verplanck, 1985, cited in Walker and Duncan, 1989). Similar lava flows in the headwaters of the Middle Fork of the Willamette River are as young as 3.23 Ma (Sherrod, 1991), although their relation to high terrace deposits farther downstream is less certain. Weathered terrace gravel deposits near Molalla are probably closely coeval with Boring Lava erupted from several vents at similar altitudes north of the map area near Oregon City, where 10 radiometric ages on separate flows span $0.427 \pm 0.026 \mathrm{Ma}$ to $3.146 \pm 0.062 \mathrm{Ma}$ (Madin, 1994). Incremental heating Ar-Ar experiments with two obsidian clasts collected from a terrace exposure along Inman Creek near the west shore of Fern Ridge Reservoir yielded ages of $0.7-0.8 \mathrm{Ma}$, although both analyses were discordant, and the ages should be considered tentative (Appendix 1). If these Inman Creek dates are accurate, deposition of the weathered terrace gravels in the southern Willamette Valley culminated after about $0.8 \mathrm{Ma}$. A $0.420 \mathrm{Ma}$ lahar within gravel underlying the valley floor near Eugene (described below) likely postdates unit QTg in the southern Willamette Valley, thus putting a younger limit on the age of the weathered terrace gravels. In summary, these weathered terrace deposits could locally be as old as 3-5 Ma, but were perhaps mostly deposited between 2.5 and $0.5 \mathrm{Ma}$, and are probably all older than about $0.4 \mathrm{Ma}$.

Origin.-The widespread preservation of multiple levels of terraces composed of unit QTg indicates periods of landscape stability after regional aggradation of fluvial deposits. Nevertheless, the terraces are too high and deformed (fig. 4) to be the product solely of climatic influences as postulated by Allison (1936, 1953), and their present positions must be partly the product of tectonic disturbances within and surrounding the Willamette Valley. On the eastern margins of the northern Willamette Valley and in the western foothills of the Cascade Range, the terraces are likely uplifted by faulting and deformation during Tertiary and Quaternary structural development of the northern Willamette Valley or by early Pliocene uplift of the Cascade Range (Sherrod, 1986; Priest 1990). Along the western margins of the southern Willamette Valley, however, there is little evidence of late Tertiary or Quaternary uplift or faulting, and it is probable that the extensive terraces and pediments along the eastern foothills of the Coast Range reflect a regional base level 10 to $25 \mathrm{~m}$ higher than at present. This higher base level probably resulted from uplift of the structural arch forming the Salem Hills south of Salem. This would be similar to the current situation, where uplift along the Portland Hills structural zone has caused the 15-m stream discontinuity at Willamette Falls (fig. 4), which now controls regional base level for the northern Willamette Valley. Local preservation of multiple terrace levels (fig. 4; Allison, 1936) may indicate separate periods of regionally stable base level as the downcutting Willamette River and tributaries were affected by the tectonically rising Cascade Range and crossvalley structural zones.

Hydrogeologic Considerations.-The weathered terrace deposits are not a regionally important source of ground water, although they are a component of the Willamette aquifer described by Gannett and Caldwell (1998) (fig. 2). Many of these deposits are well above valley floors, are only a few meters thick, and, consequently, are above the regional water table (Piper, 1942, p. 33; Gannett and Caldwell, 1998). In locations where unit QTg is thick, the lower portion may be saturated and more permeable because of less weathering, although the clay-rich weathering profile at the surface likely restricts infiltration (Piper, 1942, p. 33). An area where these older gravels are hydrogeologically important is the broad piedmont flanking the Cascade Range foothills southwest of Molalla, where many wells penetrate up to $150 \mathrm{~m}$ of so-called Troutdale Formation sand and gravel, and produce "small to large quantities of water” (Hampton, 1972, p. 42).

\section{Pleistocene Sand and Gravel of the Willamette River and major Cascade Range Tributaries $\mathbf{Q g}_{1}$, $\mathbf{Q g}_{2}$ )}

Underlying the lowlands and valley floors and locally inset against unit QTg are varied thicknesses of unconsolidated clay, silt, sand, and gravel derived from the Coast and Cascade Ranges (fig. 3, geologic section C-C'; Gannett and Caldwell, 1998). The upper 5 to $50 \mathrm{~m}$ of these deposits is typically Quaternary-age gravel and sand deposited in thin, widespread sheets. These coarser facies as well as lower, finer facies grade south and east to large sand and gravel fan complexes where major Willamette River tributaries 
debauch from the Cascade Range (Piper, 1942; Gannett and Caldwell, 1998). Within the Cascade Range foothills, Quaternary sand and gravel deposits can be further traced up major river valleys as gravelly terrace deposits flanking modern floodplains. These sands and gravels directly correspond to the Linn Gravel as described by Allison (1936, 1953), the Rowland Formation as defined by Balster and Parsons (1969), and the Linn Formation of Roberts (1984) (fig. 1), and partly coincide with the older alluvium of Piper (1942), the Quaternary middle and lower terraces of Bela $(1979,1981)$, and the Quaternary lower terrace of Beaulieu and others (1974). Within the northern Willamette Valley, some of these deposits have been speculatively correlated to the Troutdale Formation (Glenn, 1965; Hampton, 1972) and Gresham Formation (Trimble, 1963) and have recently been mapped as a component of "fluvial and lacustrine(?)" deposits of Miocene and Pliocene age (Yeats and others, 1996). These sand and gravel deposits are a major component of the Willamette aquifer of Gannett and Caldwell (1998, fig. 2). Where exposed at the surface, Pleistocene sand and gravel deposits form portions of the Winkle and Ingram geomorphic surfaces of Balster and Parsons (1968).

We have separated the Pleistocene sand and gravel into two separate units; unit $\mathrm{Qg}_{2}$ predates the latest Pleistocene (15 to $12.7 \mathrm{ka}^{2}$ ) Missoula Floods and constitutes most of the subsurface Pleistocene sand and gravel, whereas unit $\mathrm{Qg}_{1}$ is a comparatively thin sand and gravel deposit that postdates the Missoula Floods (fig. 3). The distinction between units $\mathrm{Qg}_{1}$ and $\mathrm{Qg}_{2}$ is clear for surfaces that are traceable to altitudes below 100 to $120 \mathrm{~m}$ where mappable thicknesses of finegrained Missoula Flood deposits (unit $\mathrm{Qff}_{2}$ ) obscure the braidplain topography of the sand and gravel of unit $\mathrm{Qg}_{2}$, but do not cover sand and gravel of unit $\mathrm{Qg}_{1}$ (fig. 3, geologic section B-B'). Such relations are found along the Molalla River north of Molalla, the fan of the North Fork Santiam River within the Stayton subbasin and near Salem, the fan of the South Fork Santiam River northwest of Lebanon, and in the southern Willamette Valley between Eugene and Harrisburg. At higher altitudes in the southern Willamette Valley and major tributary valleys, above the mappable extent of Missoula Flood sediment, the distinction between pre- and post-Missoula Flood sand and gravel

\footnotetext{
2"ka" indicates thousands of years before present, and in this report refers to ages determined by radiocarbon dating. These ages have not been calibrated to calendar years.
}

deposits is less clear and tentatively inferred on the basis of topographic position and soil characteristics. Likewise, isolated gravel deposits flanking the modern Willamette River floodplain between Albany and Salem have been tentatively mapped as $\mathrm{Qg}_{1}$ on the basis of topography and soils, although they may be younger floodplain deposits. The overall geomorphology, stratigraphy, sedimentology, and hydrogeologic characteristics of units $\mathrm{Qg}_{1}$ and $\mathrm{Qg}_{2}$ are similar and are described together in the following sections; however, stratigraphic and chronologic details are described separately for each unit.

Geomorphology of Pleistocene Sand and Gravel Deposits.-In the Willamette Valley and tributary valleys above an altitude of 100-120 m, deposits of units $\mathrm{Qg}_{1}$ and $\mathrm{Qg}_{2}$ form broad fans and terraces 5 to $20 \mathrm{~m}$ above modern stream levels (fig. 5). Below 100-m altitude, deposits of unit $\mathrm{Qg}_{2}$ are buried by Missoula Flood sediment, but deposits of unit $\mathrm{Qg}_{1}$ form low terraces and fan surfaces that flank the modern floodplains of the major Cascade Range rivers. Within the larger Cascade Range tributary valleys, these units commonly form multiple terrace treads separated by risers up to $5 \mathrm{~m}$ high. These fan and terrace surfaces are planar to the eye, but detailed topographic maps show a distinct braidplain topography of multiple lenticular bar forms having streamwise lengths of about 1 $\mathrm{km}$.

Stratigraphy and Sedimentology. - The total thickness of Pleistocene sand and gravel is difficult to define precisely because the contact between coarse deposits and the underlying fine-grained basin fill is commonly gradational and complex, marking vertical time-transgressive variations in local depositional environment as well as lateral, time-equivalent facies variations between proximal and distal fan deposits (Gannett and Caldwell, 1998). Our best estimates from drillers' logs indicate that near-surface deposits of primarily sand and gravel are generally 10 to $30 \mathrm{~m}$ thick in major tributary valleys, 40 to greater than 100 $\mathrm{m}$ thick at fan apices, and 10 to $20 \mathrm{~m}$ thick in the more distal portions of larger basins (fig 3; Gannett and Caldwell, 1998). More detailed discussion on the thickness of unit $\mathrm{Qg}_{1}$ is provided in the section "Thickness and Extent of Quaternary Deposits."

Internal stratigraphy of the upper $30 \mathrm{~m}$ of these deposits is revealed in a few deep sand and gravel excavations and river cuts. Deep exposures into the fans show multiple bouldery, cobbly, sandy gravel units, and sparse lenses of sand and silt (fig. 6). Distinct gravel units are defined by variations in grain 


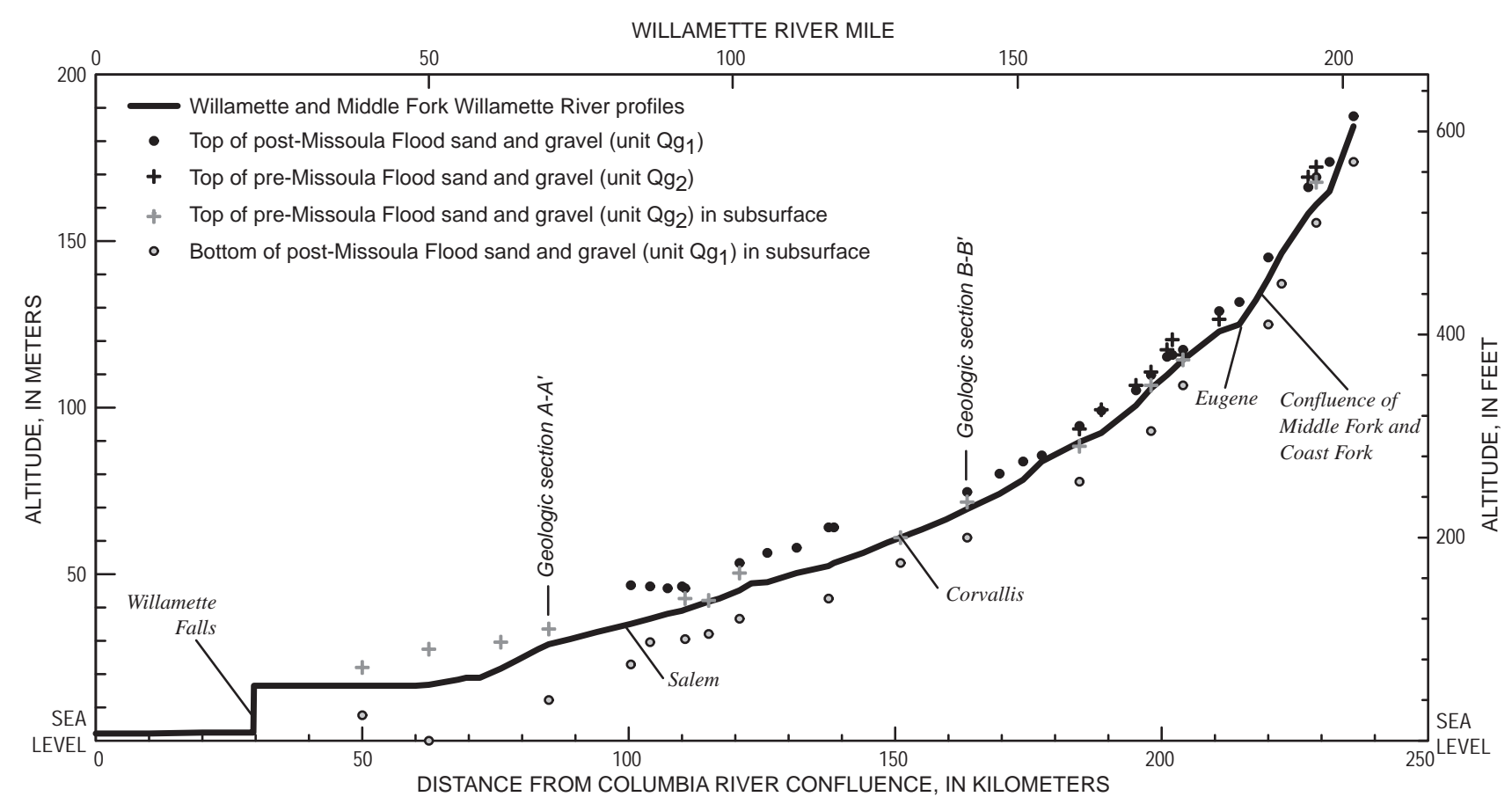

Figure 5. Tops of Pleistocene sand and gravel deposits and the base of the latest Pleistocene ( 12 ka) deposits (unit $\mathrm{Qg}_{1}$ ). (Altitudes of surface exposures of units $\mathrm{Qg}_{1}$ and $\mathrm{Qg}_{2}$ from U.S. Geological Survey topographic quadrangles. Subsurface altitudes of the top of the unit $\mathrm{Qg}_{2}$ are from stratigraphic exposures along the Willamette River and from drillers' logs. The altitudes of the bases of units $\mathrm{Qg}_{1}$ and $\mathrm{Qg}_{2}$ are inferred from drillers' logs. Distance from the Columbia River confluence was measured along the general trend of the modern floodplain ["valley kilometer"] and does not directly correspond to river miles [see plate 1 for distance indicators].)

size, sorting, and orientation of internal bedding structures, and are typically 2 to $10 \mathrm{~m}$ thick. Contacts between gravel units are typically marked by a subplanar layer of cobbles or boulders, commonly a clast or two thick, that separates oxidized and consolidated gravel below from gray, loose, openwork gravel above. Zones just below contacts are commonly less permeable, resulting in springs where contacts are exposed in dewatered excavations below the regional water table. No conclusive evidence of pedogenesis has been found below these contacts, although in one locality a burned stump, apparently in growth position (fig. 6A), shows that these contacts probably represent substantial pauses in deposition. Some units, deep in gravel pits, are distinctly finer than most, and are primarily composed of plane- and cross-bedded sand and silt.

Within individual gravel units, the stratigraphy generally consists of multiple cut and fill structures. Bedding is defined by grain size and sorting; well sorted openwork gravel generally fills the lower parts of the cuts, grading up to compact and generally finer gravel with silt and sand filling the interstices (fig. 7). Exposures parallel to paleoflow direction commonly show 0.2- to 2-m high foresets dipping downstream. Cobbles are weakly imbricated within horizontal beds.
Isolated small sand lenses (generally less than $1 \mathrm{~m}$ thick) commonly surround accumulations of wood.

Maximum clast diameters are typically 30 to 100 $\mathrm{cm}$ in tributary valleys and near fan apices, but much smaller out in the Willamette Valley. Clast diameters are typically less than $10 \mathrm{~cm}$ in exposures along the Willamette River in the southern Willamette Valley north of Harrisburg, and less than $5 \mathrm{~cm}$ in the northern Willamette Valley near Salem. Clast diameters greater than $2 \mathrm{~cm}$ are rare in the far northern part of the valley, where sand is the dominant component.

\section{Sand and Gravel Deposited before the Missoula}

Floods $\left(\mathrm{Qg}_{2}\right)$. - Sand and gravel deposited before the 15-12.7 ka Missoula Floods make up most of the Pleistocene sand and gravel deposited in the Willamette Valley. These deposits were mapped primarily on the basis of topography, geomorphic relations with Missoula Flood sediment, and NRCS soil maps. The mapped distribution of the Clackamas (Typic Argiaquolls, Aquultic Haploxerolls), Courtney (Abruptic Argiaquolls), Coburg (Pachic Ultic Argixerolls), and Awbrig (Vertic Albaqualfs) soil series were key mapping criteria where the stratigraphic relation to Missoula Flood sediment was not clear. Other soil series common on these older gravel deposits include Bried- 

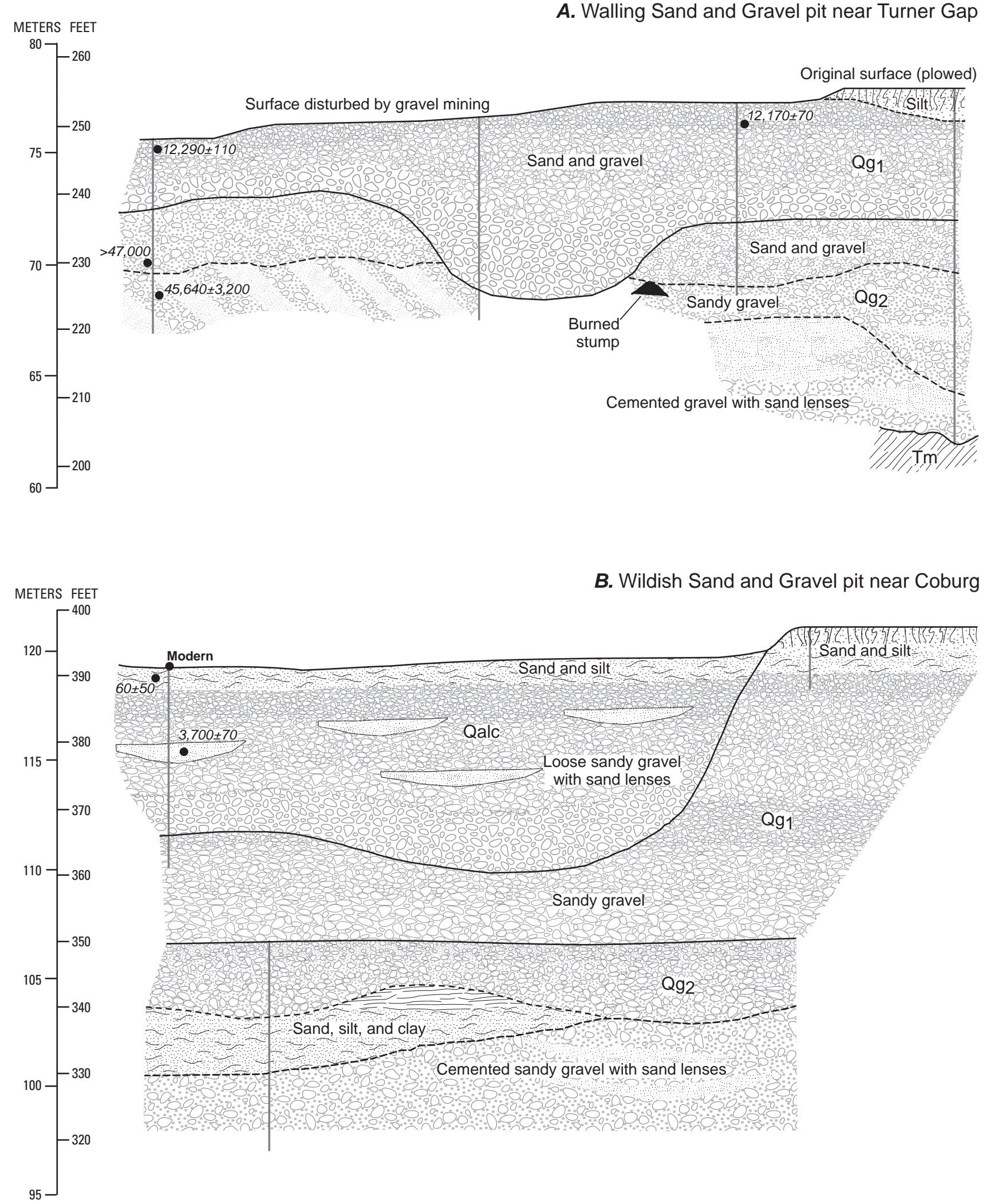

Figure 6. Stratigraphic and chronologic information for sections of late Quaternary stratigraphy exposed in deep gravel pits in the Willamette Valley. (Vertical lines indicate surveyed sections. Thickness to scale; horizontal distance not to scale, but everywhere represent distances less than 200 meters. Locations of sections are shown on plate 1; $\boldsymbol{A}$, Walling Sand and Gravel excavation near Turner Gap; B, Wildish Sand and Gravel excavation near Coburg). 


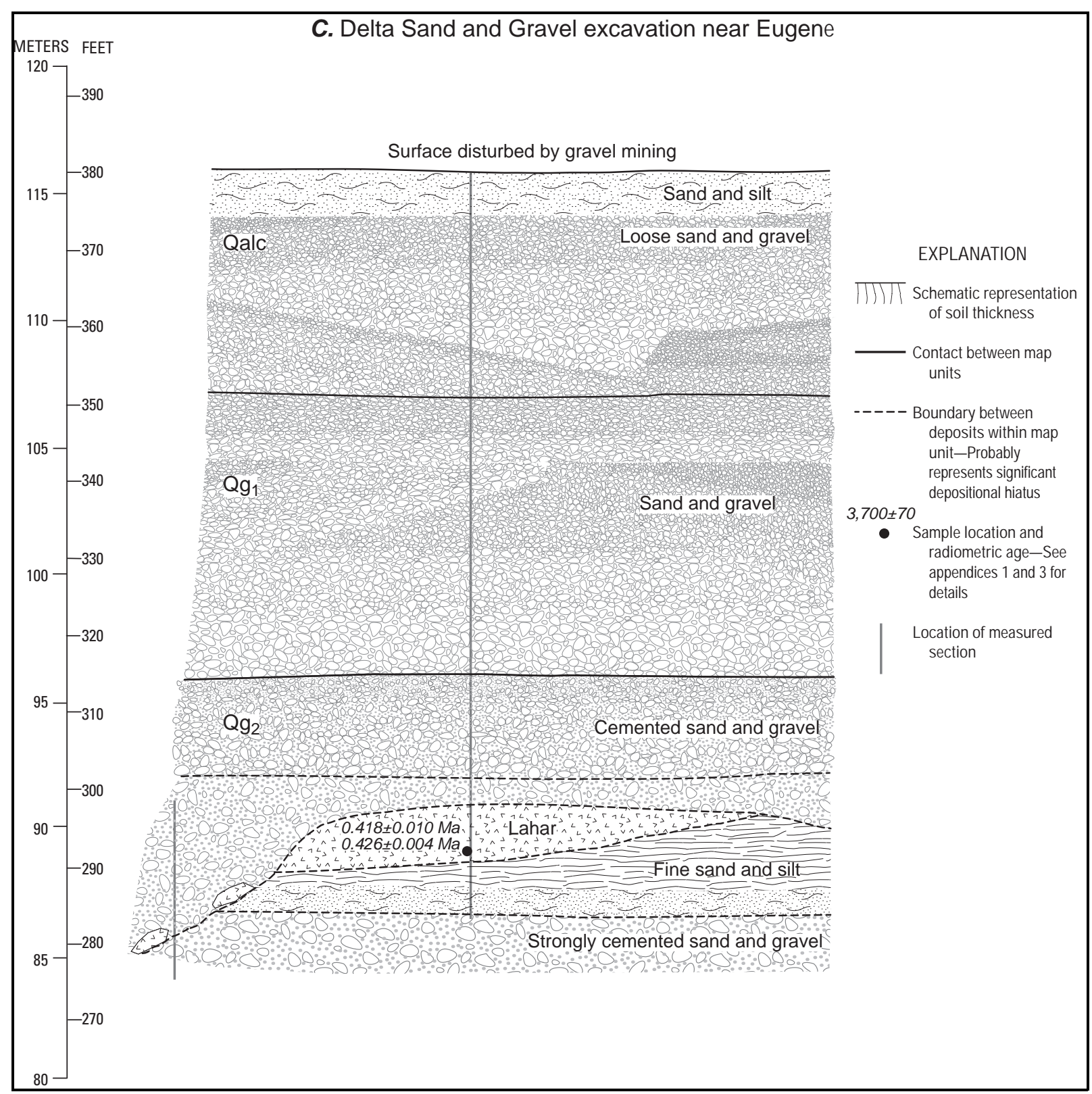

Figure 6. Late Quaternary stratigraphy exposed in deep gravel pits in the Willamette Valley. (Vertical lines indicate surveyed sections. Thickness to scale; horizontal distance not to scale, but everywhere represents distances less than 200 meters. Locations of sections are shown on plate 1; $\boldsymbol{C}$, Delta Sand and Gravel excavation near Eugene.) - Continued.

well (Ultic Haploxerolls), Conser (Typic Argiaquolls), Pengra (Typic Haplaquolls), Dayton (Typic

Albaqualfs), Holcomb (Mollic Albaqualfs), Salem (Pachic Ultic Argixerolls), Oxley (Typic Argiaquolls), Malabon (Pachic Ultic Argixerolls), and Sawtell (Ultic Argixerolls).

Deposits of unit $\mathrm{Qg}_{2}$ typically have planar surfaces or a subtle braided channel morphology where they are higher than areas of Missoula Flood deposition and exposed on the surface. Widely scattered exposures of these deposits generally show 1 to $2 \mathrm{~m}$ of sandy silt capping cobbly gravel. Weathering profiles are typically 2 to $3 \mathrm{~m}$ thick and are characterized by reddening, aggregation of individual soil particles into pedogenic structures, and incipient zones of clay accumulation. Cobbles within the uppermost few meters are typically slightly pitted where mineral grains have weathered, have reddish coatings of translocated clay and iron oxides, and have weathering rinds generally in excess of 1 to $2 \mathrm{~mm}$. The most weathered of these surfaces, such as the Linn Gravel type section near Stayton (Allison, 1953), have reddened weathering profiles 


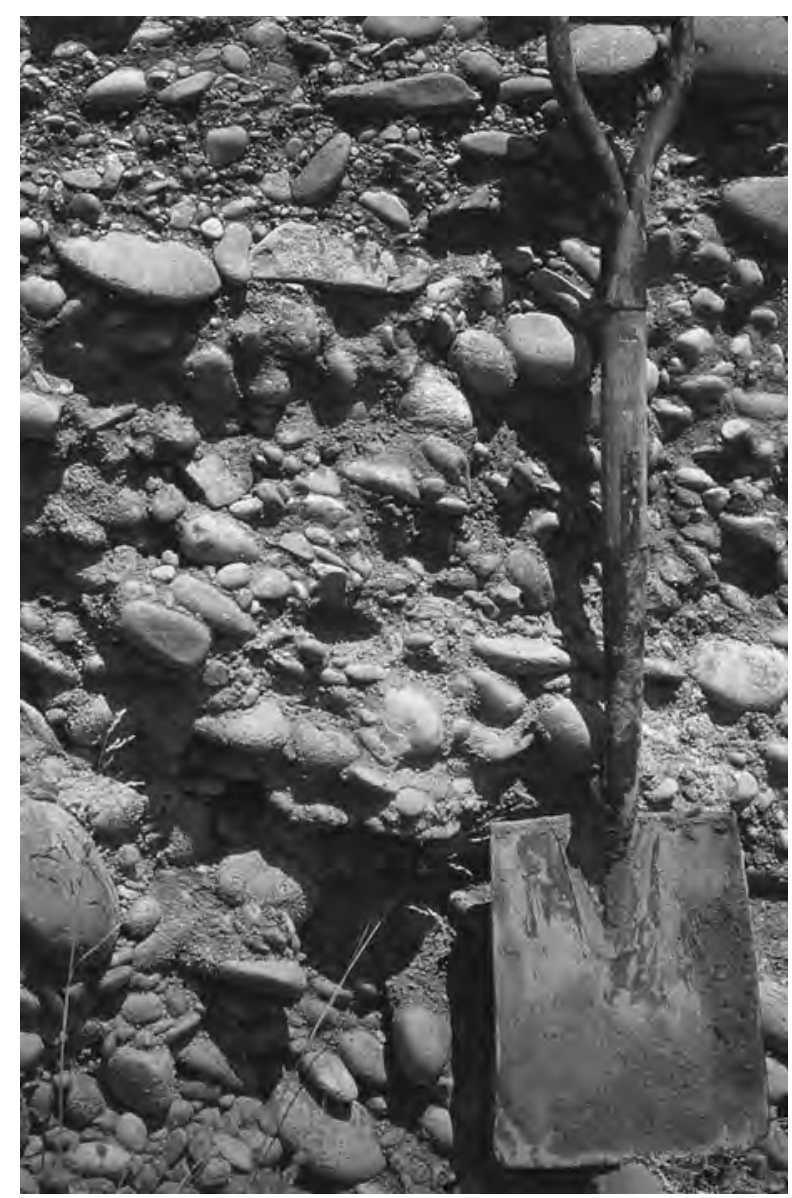

Figure 7. Pleistocene sand and gravel exposed at Walling Sand and Gravel pit near Turner Gap. (Shovel is approximately 1 meter long.)

of about $3 \mathrm{~m}$, argillic horizons (Scott Burns, Portland State University, written commun., 1997), and weathering rinds greater than $5 \mathrm{~mm}$ on fine-grained volcanic cobbles.

In each of two deeper pits near Eugene and Salem, the sequence of multiple sand and gravel layers composing unit $\mathrm{Qg}_{2}$ is interrupted by deposits of volcanic debris flows, or lahars. At the River Bend Sand and Gravel quarry near the southern city limits of Salem, a $15 \mathrm{~m}$ deep pit exposes a gray, pumiceous lahar deposit between gravel beds (fig. 8). The top of the lahar deposit is $13 \mathrm{~m}$ below the original ground surface (altitude $70 \mathrm{~m}$ above sea level) and has a maximum exposed thickness of $2.0 \mathrm{~m}$. The deposit fills a $30-\mathrm{m}-$ wide paleochannel and pinches out laterally between gravel units. The lahar deposit grades upward from a round-cobble, clast-supported gravel to a massive, hard, sandy silt enclosing abundant matrix-supported subrounded pumice and angular lithic fragments.

The chemical composition of glass in the pumice clasts matches that of a thick pumice-fall deposit from the last major explosive eruption of Mount Jefferson (Appendix 2). During or shortly after this eruption, a lahar flowed at least $120 \mathrm{~km}$ down the North Fork Santiam River from the flanks of Mount Jefferson through Turner Gap to where it is now exposed near Salem. Stratigraphic relations in a trench in eastern Idaho show that this Mount Jefferson eruption closely predates a Yellowstone tephra that has a $0.076 \pm 0.034 \mathrm{Ma}$ fission track date (Pierce, 1985), thus indicating that the Mount Jefferson lahar is probably 0.042-0.110 Ma.

Similarly in a Delta Sand and Gravel Company excavation near the northern city limits of Eugene, a prominent lahar deposit is exposed about $25 \mathrm{~m}$ below the original $115 \mathrm{~m}$ altitude ground surface (fig. 6). This lahar deposit was first noted by geologists from the Oregon Department of Geology and Mineral Industries (John Beaulieu, oral commun., 1996). The lahar deposit also fills a paleochannel, but pinches out over about $30 \mathrm{~m}$ between fluvial sand and gravel units from its maximum exposed thickness of $2.2 \mathrm{~m}$. The lahar deposit consists of indurated, light-gray, ashy sandy

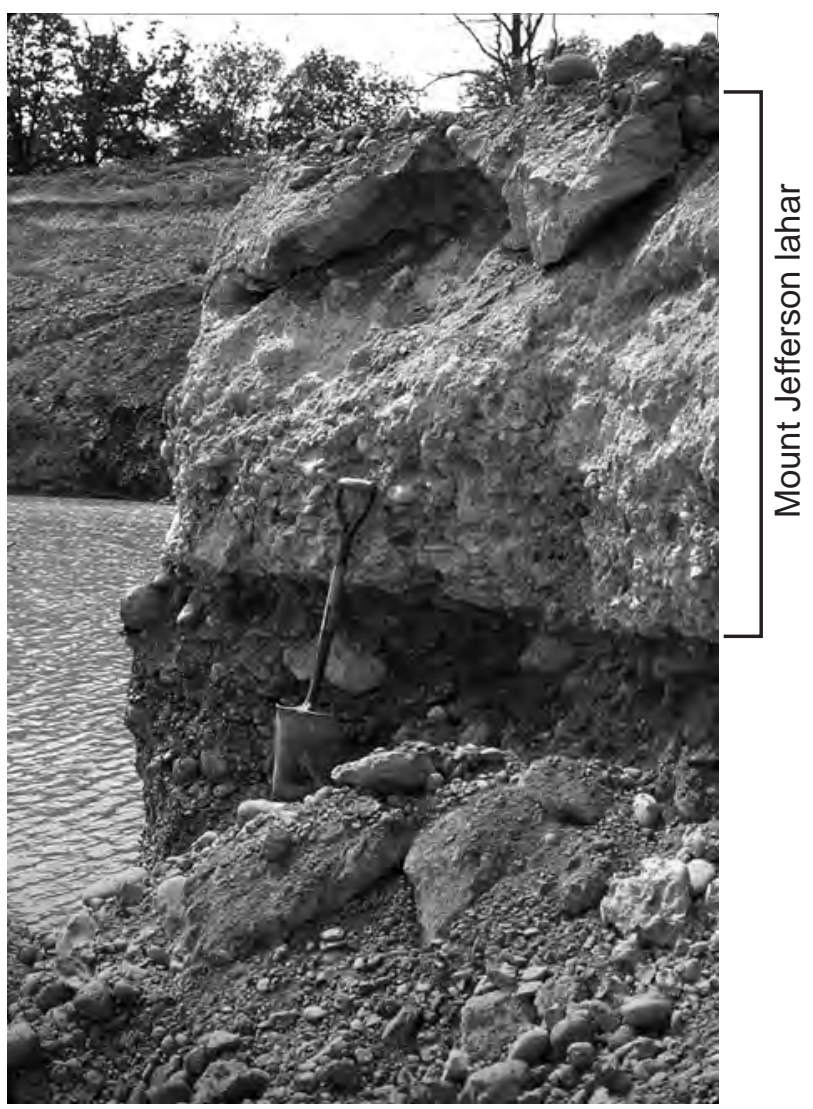

Figure 8. Lahar deposit derived from Mount Jefferson. (Lahar is about 1 meter thick, and is exposed about 15 meters below the land surface in an River Bend Sand and Gravel excavation south of Salem. (Shovel is about 1 meter long.) 
silt, supporting gravel-size fragments (about 40 percent by volume) of light-gray, angular, glassy rhyodacite (80 percent), angular black obsidian fragments (20 percent), and rarer rounded pebbles, cobbles, and pumice lapilli of diverse lithologies. A distinct feature of this deposit is abundant subrounded to subangular clasts of black obsidian having maximum diameters as great as $15 \mathrm{~cm}$. The composition and location of this deposit indicates a major Cascade Range silicic eruption that produced a lahar that traveled down the McKenzie or Middle Fork Willamette Rivers. A source for this deposit is not known, but Ar-Ar incremental heating analyses of two obsidian clasts yielded ages of $0.418 \pm 0.010 \mathrm{Ma}$ and $0.426 \pm 0.004 \mathrm{Ma}$ (Appendix 1).

If the obsidian is coeval with the lahar deposit, which we tentatively infer because of its high concentration within the deposit and its unweathered appearance, these about-0.42-Ma ages provide a minimum constraint on the maximum age of the large gravel and sand fan formed by the McKenzie and Willamette Rivers in the southern Willamette Valley.

At lower altitudes along the axis of the Willamette Valley, erosion by the Willamette River on the outsides of several large bends has maintained fresh exposures of the top of unit $\mathrm{Qg}_{2}$ buried beneath 1 to

$17 \mathrm{~m}$ of Missoula Flood sediment (fig. 9). These exposures, such as those at Irish Bend and River Bend, have been the basis for several key studies of the late Quaternary stratigraphy of the Willamette Valley (Allison, 1936, 1953; Glenn, 1965; Balster and Parsons, 1969). Such exposures in the southern Willamette Valley typically show 2 to $3 \mathrm{~m}$ of cobbly gravel near river level fining up to cross-bedded and planelaminated sand and silt conformably overlain by a 1to 2-m paleosol formed in clayey silt. In the northern valley, exposures of $\mathrm{Qg}_{2}$ are thicker, typically revealing 5 to $10 \mathrm{~m}$ of cross-bedded sand and isolated gravel lenses up to $2 \mathrm{~m}$ thick, capped by a 1- to 2-m thick paleosol developed in conformably overlying silt and clay (fig. 10). The sand and gravel is typically weakly cemented by clay, calcite, and iron oxides (Glenn, 1965; Balster and Parsons, 1969), locally forming resistant ledges of sand and gravel that follow bedding.

At almost all locations where the top of unit $\mathrm{Qg}_{2}$ has been examined, sandy layers contain abundant rounded pumice grains. The pumice grains are white to light yellow and have diameters ranging from less than $1 \mathrm{~mm}$ to as large as $2 \mathrm{~cm}$. Within small zones of cross-bedded sand, pumice grains locally exceed 90 percent of the total grains. Most of these pumice grains are close compositional matches to three pumice layers and tephras erupted from Cascade Range sources primarily between 28 and $23 \mathrm{ka}$ (Appendix 2). The youngest of these tephras is $23.2 \mathrm{ka}$, indicating that these sands and gravels were locally deposited until at least that time. A radiocarbon date of 22,060土 $100{ }^{14} \mathrm{C} \mathrm{yr} \mathrm{BP}^{3}$ from grass fragments on top of the overlying paleosol at the Wheatland Ferry section (fig. 10; Appendix 3) appears to tightly constrain the end of deposition to between $23 \mathrm{ka}$ and $22 \mathrm{ka}$.

These results are consistent with a 28,480 $\pm 1,810$ ${ }^{14} \mathrm{C}$ yr BP age obtained by Roberts (1984) from wood within fluvial sand at an equivalent stratigraphic position along the western margin of the southern Willamette Valley near Monroe. Additionally, Glenn (1965, p. 178) reported an age of $34,410 \pm 3,450{ }^{14} \mathrm{C}$ yr BP from a $\log 6 \mathrm{~m}$ below the modern surface in a nowabandoned pit near Salem. These ages are inconsistent with much older age assignments for this unit by Trimble (1963, p. 55-56), Balster and Parsons (1969), and Glenn (1965) on the basis of an infinite (>40 ka) radiocarbon date (at an unspecified location) and the seemingly strong development of the capping paleosol.

Pleistocene Sand and Gravel Deposited after the Missoula Floods $\left(Q g_{1}\right)$.- - A thin but widespread unit of sand and gravel that postdates the Missoula Floods was mapped on the basis of topography, geomorphic relations with Missoula Flood sediment, and soil types as mapped by the NRCS. Pleistocene sand and gravel deposited after the Missoula Floods has not been explicitly recognized in previous work; however, Allison (1953) and Allison and Felts (1956) implicitly identified surfaces associated with these deposits by mapping an "eroded phase" of the Linn Gravel along the South Fork Santiam River near Albany. Similar deposits and geomorphic relations are found along the Molalla, North Fork Santiam, McKenzie and Willamette Rivers where gravel terraces at altitudes below the general limits of Missoula Flood deposition are not covered by Missoula Flood deposits.

Like the older sand and gravel of unit $\mathrm{Qg}_{2}$, these deposits also form planar surfaces above the modern

${ }^{3 .}{ }^{14} \mathrm{C}$ yr BP" indicates radiocarbon years before present, where present is A.D. 1950. Stated uncertainty $\pm 1 \sigma$ on basis of combined measurements of the sample, background, and modern reference standards. Complete data for all radiocarbon age analyses performed in this study are given in Appendix 3. 


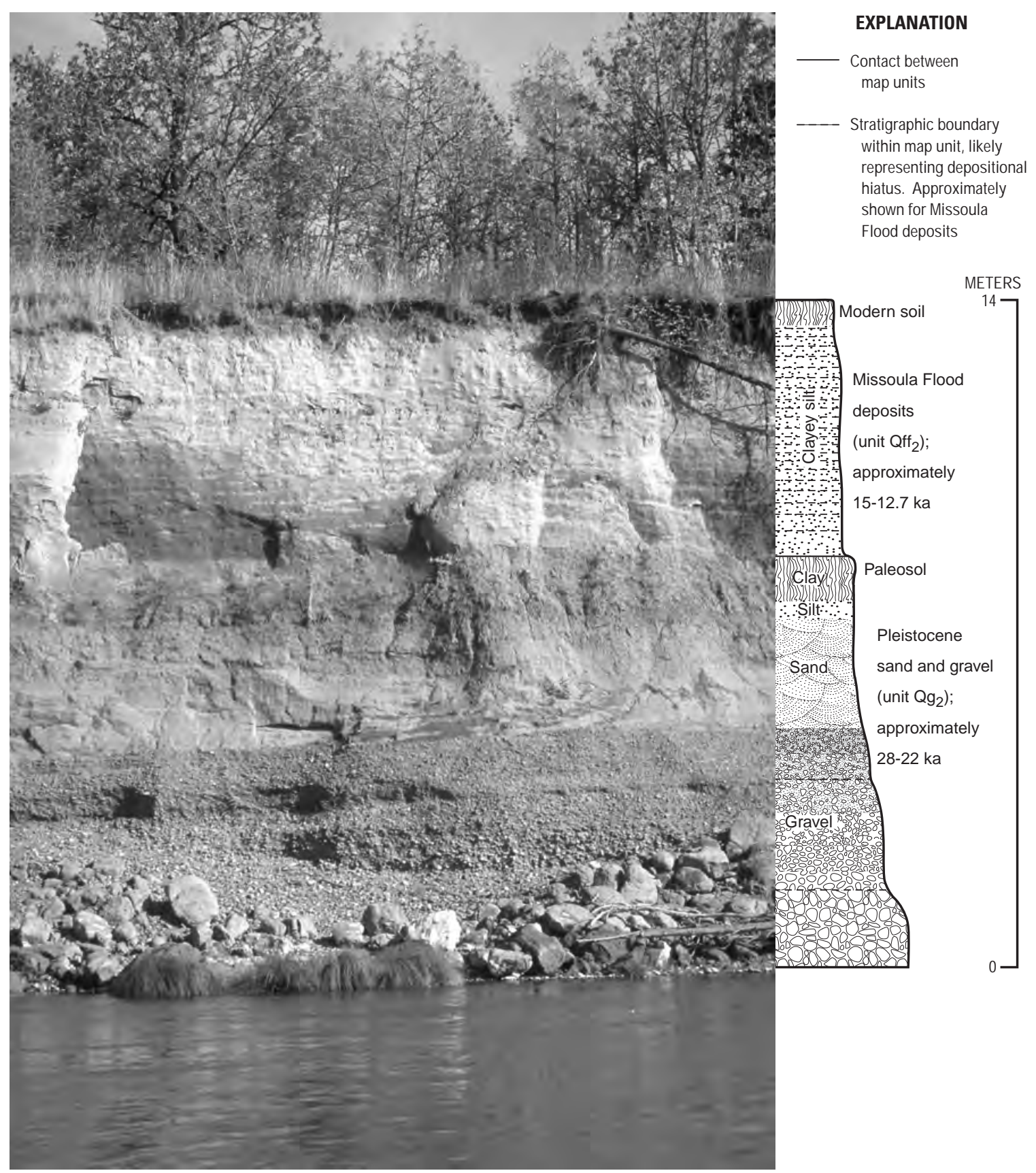

Figure 9. Pleistocene deposits exposed on the east bank of the Willamette River at river mile 102.5 near Sidney. (More than 10 beds of fine-grained Missoula Flood deposits [unit $\mathrm{Qff}_{2}$ ] overlying sand and gravel of unit $\mathrm{Qg}_{2}$ are shown.)

floodplain (figs. 3 and 5). Surfaces formed of unit $\mathrm{Qg}_{1}$ deposits are generally distinguishable from younger deposits by their clear braidplain morphology that is noticeably distinct from the meandering- and anastomosing-channel topography of the modern floodplains of most of the major rivers, although some higher-gradient reaches of the present rivers are transitional between meandering and braided, and the flanking floodplain deposits of these higher-gradient reaches also have morphologies transitional between meandering and braided. The distinction between surfaces formed of unit $\mathrm{Qg}_{1}$ and modern floodplain deposits is also slightly blurred in the southern Willamette Valley where Pleistocene surfaces composed of units $\mathrm{Qg}_{1}$ and $\mathrm{Qg}_{2}$ have been historically flooded and perhaps mantled by thin veneers of younger sediment (fig 3, geologic section B-B'; Parsons and Herriman, 1969). The contrast between surficial deposits of unit $\mathrm{Qg}_{1}$ and 


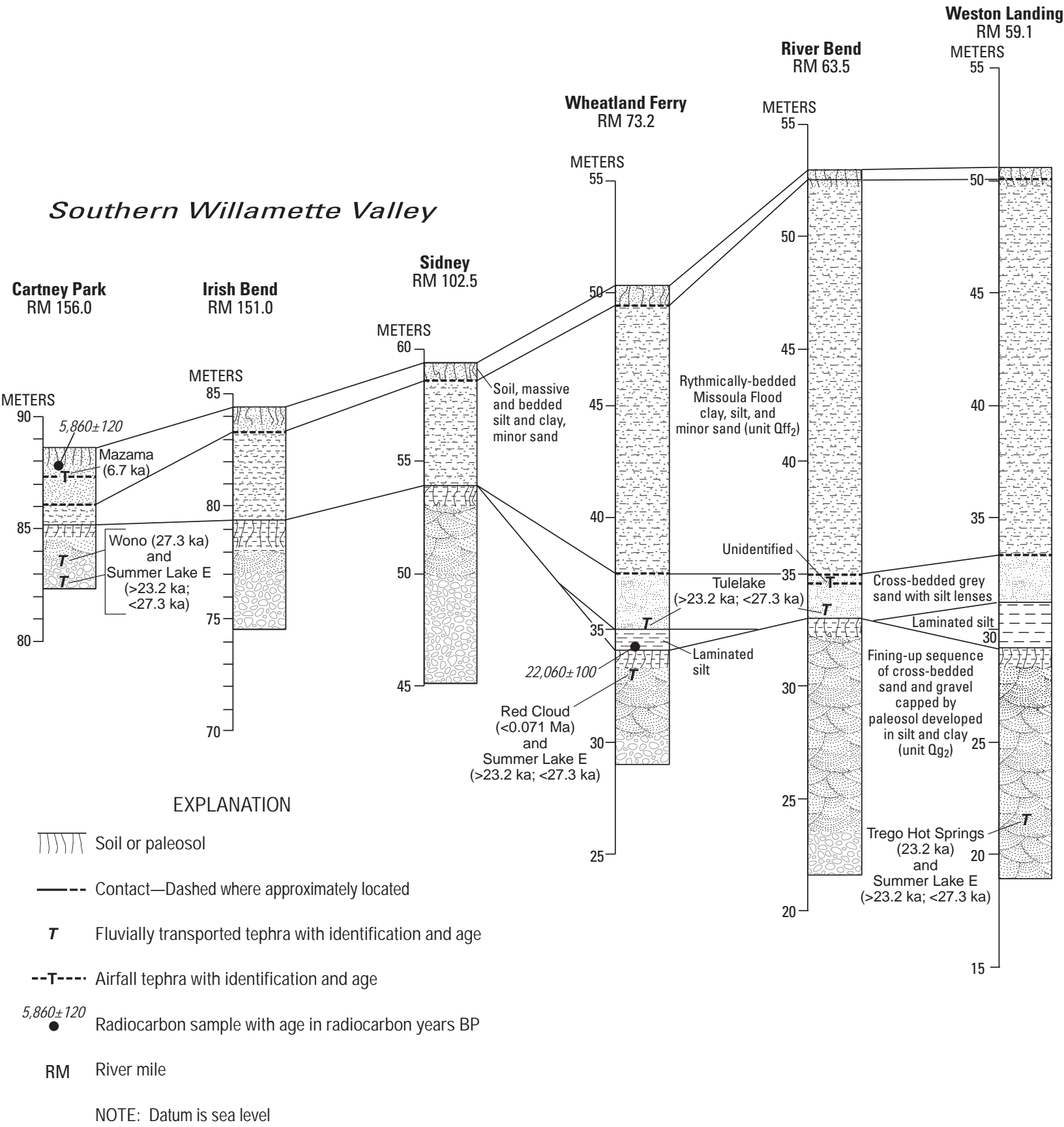

Figure 10. Correlation of stratigraphic sections measured from exposures along the Willamette River showing locations of tephra and radiocarbon samples, and the nature of contact between the main body of Missoula Flood deposits (unit Qff ${ }_{2}$ ) and the Pleistocene sand and gravel that predates the Missoula Flood deposits (unit $\mathrm{Qg}_{2}$ ). (The thin layers of silt and clay capping the Missoula Flood deposits were judged too thin to constitute a separate map unit. The laminated silt and cross-bedded grey sand with silt lenses between the Pleistocene sand and gravel of unit $\mathrm{Qg}_{2}$ and the Missoula Flood deposits [unit Qff ${ }_{2}$ ] are nowhere exposed on the surface and consequently are not a map unit. Altitudes for each section are in meters above sea level. Altitudes for River Bend section modified from McDowell and Roberts [1987] assuming a river level of 21.6 meters [71 feet]; altitudes of Irish Bend section after Roberts [1984]. The Cartney Park section was measured completely. The Sidney, Wheatland Ferry, and Weston Landing sections were all measured from river level to at least the base of the rhythmically bedded fine-grained Missoula Flood deposits [unit $\mathrm{Qff}_{2}$ ] and the absolute altitudes and total thicknesses of these sections were determined from the altitude of the river and the tops of the sections as estimated from U.S. Geological Survey topographic quadrangles. Locations of sections are shown on plate 1.) 
the slightly older Pleistocene sand and gravel of unit $\mathrm{Qg}_{2}$ is even more obscure above the limits of substantial Missoula Flood deposition, but the deposits of unit $\mathrm{Qg}_{1}$ seemingly have a slightly more clearly defined braidplain morphology than that of the older deposits of unit $\mathrm{Qg}_{2}$, which have been apparently thinly covered in many areas by silt and clay from Missoula Floods, windblown sediment, and overbank deposits. Many of the soils mapped on unit $\mathrm{Qg}_{1}$ deposits are also found on adjacent, older sand and gravel deposits; however, the Salem and Malabon soil series (both are Pachic Ultic Argixerolls) are generally diagnostic of unit $\operatorname{Qg}_{1}$ deposits.

Post-Missoula Flood Pleistocene sand and gravel was deposited in broad, fan-shaped swaths where each of the major Cascade Range tributaries exited the Cascade Range. In addition, terraces of similar deposits were formed along the Willamette River between Albany and Salem, and along Butte Creek in the northern Willamette Valley. Aggradation associated with deposition of this unit led to major shifting of river courses throughout the Willamette lowland during this period, resulting in both the North and South Forks of the Santiam River significantly changing their locations of confluence with the Willamette River. The South Fork Santiam River at times took a more direct route from its fan apex near Lebanon to a confluence with the Willamette River at the present location of Albany, subsequently switching to its present, more northerly route. The North Fork Santiam River flowed through Turner Gap during periods of deposition of unit $\mathrm{Qg}_{1}$, joining the Willamette River at Salem, instead of its present more southwesterly route from the apex of its fan near Stayton to eventually join the South Fork Santiam River and then Willamette River about $25 \mathrm{~km}$ upstream of the location of its former Salem-area confluence. These channel changes resulted in removal of much of the finegrained Missoula Flood deposits (unit $\mathrm{Qff}_{2}$ ) from the Stayton subbasin and Salem areas, and in a broad track between Albany and Lebanon.

Surface exposures of unit $\mathrm{Qg}_{1}$ typically show 1 to $2 \mathrm{~m}$ of massive silt overlying bedded sandy gravel. Pedogenic features are largely confined to the overlying silt, which is typically slightly reddened, and locally has a coarse, prismatic structure, but nowhere have pedogenic argillic horizons formed. Cobbles within the upper few meters are slightly reddened by thin and discontinuous coatings of clay and iron oxides, and typically have weathering rinds of about $0.5 \mathrm{~mm}$ or less.

The stratigraphy of unit $\mathrm{Qg}_{1}$ deposits was examined most closely at an active Walling Sand and Gravel Company excavation near Turner Gap (fig. 6A). Turner Gap is a narrow pass at the northwest corner of the Stayton subbasin through which Mill Creek presently flows, but in the past has occasionally contained the North Fork Santiam River when it flowed northwest out of the Stayton subbasin and joined the Willamette River near the present location of Salem. The North Fork Santiam River last flowed through Turner Gap sometime after deposition of Missoula Flood sediment, leaving cobbly gravel deposits and carving scarps into Missoula Flood sediment in the Stayton subbasin and along a 1- to 3-km-wide swath northwest through the present site of Salem. Exposures in the 17-m-deep gravel pit at Turner Gap reveal at least four 2 to $8 \mathrm{~m}$ sand and gravel units separated by disconformities that likely represent substantial pauses in deposition (fig. 6A). The uppermost unit comprises unit $\mathrm{Qg}_{1}$, and is a gray, cobbly sandy gravel, typically about $4 \mathrm{~m}$ thick, but locally more than $7 \mathrm{~m}$ thick where it fills a paleochannel. The lower boundary of this unit is a subtle but clear and continuously traceable contact that separates loose gray gravel from an underlying bouldery, cobbly, sandy gravel partially indurated by a clay and silt matrix. Where undisturbed, the top of the unit is capped by about $1 \mathrm{~m}$ of massive silt and sand that underlies the land surface. From our observations here and at other deep pits, we infer that unit $\operatorname{Qg}_{1}$ is the youngest of multiple and distinct sand and gravel units of similar thickness and sedimentologic characteristics that have been intermittently deposited during the Pleistocene.

Two radiocarbon ages from fluvially transported wood within unit $\mathrm{Qg}_{1}$ at separate locations in the Walling Sand and Gravel pit at Turner Gap yielded mutually consistent ages of 12,290 \pm 110 and $12,170 \pm 70$

${ }^{14} \mathrm{C}$ yr BP. These ages are consistent with geomorphic relations indicating deposition after the Missoula Floods, and demonstrate a latest Pleistocene pulse of deposition after the one that produced the 23-22 ka surface formed from the youngest deposits of unit $\mathrm{Qg}_{2}$. Analyses of wood from deeper units in the Turner pit yielded ages of 45,640 $\pm 3,200$ and $>47,000$ ${ }^{14} \mathrm{C}$ yr BP, indicating that North Fork Santiam River has repeatedly occupied this route during the late Pleistocene, switching back and forth between its present course and the one through Turner Gap. 
The 12.3- and 12.2-ka ages from unit $\mathrm{Qg}_{1}$ at Turner Gap (fig. 6A) indicate a short pulse of deposition as the North Fork Santiam River aggraded while flowing through Turner Gap, but other similar deposits in the Willamette Valley may have formed somewhat earlier or later. The regional stratigraphic framework constrains the age of unit $\mathrm{Qg}_{1}$ to between the 15- to 12.7-ka Missoula Floods (Waitt, 1980, 1985; Atwater, 1986) and the 6.7-ka Mazama tephra (a widely dispersed tephra erupted from the Mount Mazama eruption that formed Crater Lake). Despite this uncertainty, we infer that most of these unit $\mathrm{Qg}_{1}$ deposits were formed within several hundred years of $12 \mathrm{ka}$ because of their limited extent and the absence of multiple surfaces.

\section{Origin of Pleistocene Sand and Gravel Depos-} its.-The braidplain surface morphologies and internal stratigraphy of multiple, shallow channels indicate that units $\mathrm{Qg}_{2}$ and $\mathrm{Qg}_{1}$ were formed during periods of channel instability, high sediment supply, and a sediment load consisting primarily of bedload (Church, 1992). Overall channel morphology was likely driven by high rates of sand and gravel delivery to the major stream systems, leading to wide and shallow channels that were constantly migrating around point bars and islands of freshly deposited bedload (see, for example, Fahnestock, 1963; Church, 1972). These surfaces, as well as the underlying sand and gravel, can be traced to large fans emanating from major Cascade Range tributaries, indicating that most sediment was derived from the Cascade Range (Piper, 1942; Gannett and Caldwell, 1998). Contacts between sand and gravel units likely record depositional hiatuses and times when streams were more incised, similar to the present situation of Holocene rivers and floodplains that occupy levels lower than adjacent late Pleistocene terraces. Within the southern Willamette Valley, aggradation of the valley fill has episodically continued since at least $0.42 \mathrm{Ma}$, raising the lowland surface by about $20 \mathrm{~m}$ in the vicinity of Eugene (fig. 6C).

The 28- to 22-ka (uppermost $\mathrm{Qg}_{2}$ ) and 12-ka (unit $\mathrm{Qg}_{1}$ ) pulses of deposition must indicate distinctly different regional environmental conditions in the Cascade Range than at present. Although there is little information of the timing of glacial advances in the Cascade Range in Oregon, the ages of sand and gravel deposition are broadly consistent with times of glacier advances in western North America (Porter and others, 1983; Clark and Bartlein, 1995; Swanson and Porter, 1997). The 28- to 22-ka period of deposition closely coincides with the maximum late Pleistocene extent of alpine ice in Rocky Mountains and with more poorly dated alpine ice advances in the Washington Cascade Range in Washington (summarized by Clark and Bartlein, 1995). The 12-ka pulse of deposition that formed unit $\mathrm{Qg}_{1}$ is also coincident with a minor-but regionally detected-alpine glacier advance in the Washington Cascade Range (Swanson and Porter, 1997) and Sierra Nevada in California (Clark, 1997; Clark and Gillespie, 1997) and a readvance of the Cordilleran Ice Sheet in southern British Columbia (Armstrong, 1981; Clague and others, 1997). The 12 ka aggradation of Willamette Basin rivers seemingly predates an 11- to 9-ka aggradation episode noted by Personius and others (1993) in the Oregon Coast Range.

Despite coinciding with times of regionally advanced glaciers, it is unlikely that these aggradation pulses were derived entirely from sediment produced directly by glaciers. Only about 10 percent of the Cascade Range within the Willamette River Basin was covered by ice sheets or glaciers during maximum late Pleistocene advances (see fig. 3 in Crandell, 1965), and a much smaller percentage would have been glaciated at $12 \mathrm{ka}$. Much of the increased sediment load probably resulted from increased hillslope sediment production from enhanced landsliding, periglacial processes, and physical weathering during episodes of glacial climates.

Hydrogeologic Considerations. - Except for the top few meters, Pleistocene sand and gravel of units $\mathrm{Qg}_{1}$ and $\mathrm{Qg}_{2}$ are generally saturated and are a principle source of ground water within the Willamette Valley and a major component of the Willamette aquifer (Gannett and Caldwell, 1998; Woodward and others, 1998). Hydrogeologic properties are chiefly controlled by sedimentary characteristics such as clast size and sorting. These Pleistocene deposits were left by wide, shallow, and braided streams that formed broad fans as they flowed from the Cascade Range, resulting in a subhorizontal stratigraphy of amalgamated ribbons and sheets of gravel and sand. Their composition varies from cobbly, sandy gravel in the major tributary valleys and fan apices to silt and sand in distal portions of the main basins, although particularly coarse layers have distal facies of sand and gravel (Piper, 1942; Gannett and Caldwell, 1998). The depositional facies vary widely, ranging from well sorted openwork gravel left in channel thalwegs, to less-sorted bar deposits of sandy gravel containing a compact silty clay matrix. These facies variations can be observed over lateral distances of $10 \mathrm{~m}$ or less and vertical distances on the scale of meters, and probably control hydrogeologic characteristics over distances of a few 
hundred meters or less (Piper, 1942). This is visible in dewatered gravel pits, where most of the seepage into a pit will enter from a few well-defined zones (described by Piper as "arteries") composed of coarse channel facies of well sorted sand or gravel. Nevertheless, over horizontal distances of more than a few hundred meters, such facies variations likely even out and at these broader scales the Pleistocene sand and gravel deposits can probably be considered laterally homogenous with respect to hydrogeologic properties, although there may be some systematic variation with respect to paleoflow direction due to greater connectivity of coarser facies in streamwise directions.

Postdepositional diagenesis and compaction are also factors likely affecting hydrogeologic properties. Deeper and older sand and gravel is noticeably more cemented and compact than units near the surface. Typically, the upper 5 to $10 \mathrm{~m}$ of sand and gravel fails to hold vertical faces, collapses into shovels when excavated during gravel extraction, and readily disaggregates into individual grains. Deeper sand and gravel holds free faces and is more difficult to excavate. The deepest layers exposed, typically 20 to $30 \mathrm{~m}$ below the surface, are tightly cemented and typically break into conglomeratic aggregates rather than individual grains. The cementing agents include silt and clay, iron and manganese oxides, and silica or calcium carbonate. The varied cementation and consolidation of these deposits probably result in an overall decrease in permeability at deeper levels, although the distribution of springs within deep pits clearly shows that there are zones of relatively high permeability at all depths owing to facies variations within sand and gravel units and local differences in the degree of cementation. Woodward and others (1998, p. 32-35) compared drillers' logs for wells of different depths in the Willamette aquifer and concluded that the specific yield for wells deeper than $15 \mathrm{~m}$ (50 feet) (which are likely drawing water primarily from unit $\mathrm{Qg}_{2}$ ) was less than that for shallower wells completed primarily in shallower alluvium (mostly units $\mathrm{Qg}_{1}$ and Qalc). As a general rule, our field observations are that the younger Pleistocene deposits mapped as unit $\mathrm{Qg}_{1}$ are looser and less cemented than are unit $\mathrm{Qg}_{2}$ deposits, which include the deep and compacted sand and gravel layers, although there is substantial variation within deposits of both units.

\section{Missoula Flood Deposits (Qfc, Qff 1 , Qff ${ }_{2}$ )}

Most of the lowland of the Willamette Valley is blanketed by deposits from multiple floods from Gla- cial Lake Missoula (fig. 9). Most of these deposits consist of subparallel sheets of silt, clay, and sand that cover the valley floor and margins to an altitude of 120 $\mathrm{m}$ above sea level. These valleywide deposits of finegrained Missoula Flood sediment have been mapped as unit Qff 2 . They have a Columbia River Basin provenance and commonly enclose isolated pebbles, cobbles, and boulders of granitic and metamorphic lithologies that are foreign to the Willamette River Basin. Unit Qff 2 becomes progressively sandier to the north and grades to two bouldery gravel fans near Canby at the northern entrance to the Willamette Valley. These gravel fans have been separately mapped as unit Qfc. In the northern Willamette Valley, along the Willamette River and Labish channel, a lower deposit of stratified silt, sand, and clay of probable Missoula Flood origin is inset into units $\mathrm{Qff}_{2}$ and Qfc, and has been mapped as unit $\mathrm{Qff}_{1}$. Together, these three units of Missoula Flood deposits largely correspond to the Willamette Silt as defined by Allison (1953), and the Willamette Formation of Balster and Parsons (1969). They are a component of the older alluvium of Piper (1942), and the Willamette Silt hydrogeologic unit of Gannett and Caldwell (1998), except for the coarsegrained unit Qfc which Gannett and Caldwell (1998) included in the Willamette aquifer hydrogeologic unit. Missoula Flood deposits are correlative to the "upper Pleistocene lacustrine deposits" mapped by Trimble (1963) in the northern Willamette Valley and Portland Basin, and Pleistocene "catastrophic flood" deposits in the Portland area (Beeson and others, 1989, 1991). They typically underlie the Calapooyia and Senecal geomorphic surfaces of Balster and Parsons (1968).

Geomorphology and Distribution.-In the northern Willamette Valley, the main body of fine-grained flood deposits (unit $\mathrm{Qff}_{2}$ ) forms planar or slightly undulating geomorphic surfaces between 45 and $60 \mathrm{~m}$ above sea level, and mantles the flanking foothills and piedmont surfaces up to an altitude of $120 \mathrm{~m}$ above sea level before pinching out against older units (Glenn, 1965). Within the lowlands, the deposits have been dissected by as much as $35 \mathrm{~m}$ by the Willamette River and local tributaries. In the southern valley, the Missoula Flood deposits underlie a remarkably planar and undissected surface (Balster and Parsons, 1968) that obscures the braidplain topography of underlying gravel surfaces to altitudes between 100 and $120 \mathrm{~m}$ (fig. 11). 


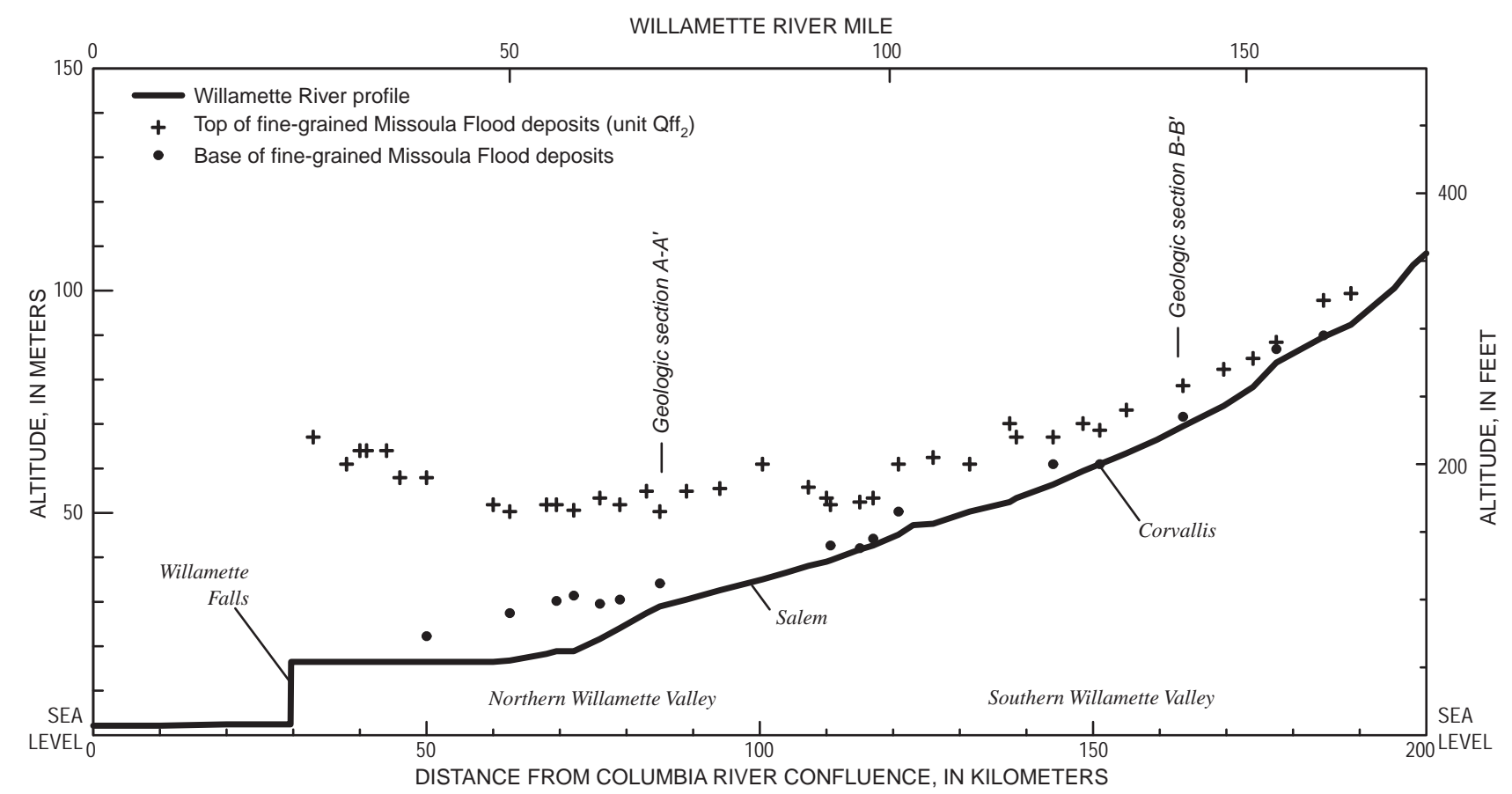

Figure 11. Altitude and thickness of fine-grained Missoula Flood deposits (unit $\mathrm{Qff}_{2}$ ). (Top altitude taken from U.S. Geological Survey topographic quadrangles; bottom altitude from stratigraphic exposures along the Willamette River and from drillers' logs. Distance from the Columbia River confluence was measured along the general trend of the modern floodplain ["valley kilometer"] and does not directly correspond to river miles [see plate 1 for distance indicators].)

Silt and sand deposits of unit Qff ${ }_{1}$ form surfaces inset into deposits of unit $\mathrm{Qff}_{2}$ along the Willamette River between the Yamhill confluence and Wilsonville, along the margins of the Labish channel northeast of Keizer, and within the valley of Champoeg Creek (described by Glenn [1965, p. 168], but too small to be mapped at the scale of plate 1). Almost everywhere the surface of unit Qff $_{1}$ lies at altitudes between 40 and $50 \mathrm{~m}$, which is typically 5 to $20 \mathrm{~m}$ below adjacent surfaces underlain by the main body of fine-grained flood deposits (unit $\mathrm{Qff}{ }_{2}$ ), but above historic flood levels. Deposits of unit $\mathrm{Qff}_{1}$ are of limited extent and, along the Willamette River, are locally correlative to the "second bottom deposits" of Allison (1978).

The placement of contacts for both of the finegrained Missoula Flood units $\left(\mathrm{Qff}_{1}, \mathrm{Qff}_{2}\right)$ was based on topography and soils, and, for the northern Willamette Valley, largely follows that of Glenn (1965). In many areas, Missoula Flood deposits of unit Qff 2 lap up and ultimately pinch out against older units along the margins of the basins. Exposures on the basin margins typically show up to $1 \mathrm{~m}$ of Missoula Flood silt and clay capping older units up to an altitude of $120 \mathrm{~m}$, but Missoula Flood deposits were mapped only where they obscure the original mor- phology of the underlying unit and where mapped soils were primarily those typical of flood deposits. With these criteria, Missoula Flood deposits are a mappable unit up to altitudes between 60 and $110 \mathrm{~m}$ in most locations. The Amity (Argiaquic Xeric Argiabolls), Willamette (Pachic Ultic Argixerolls), and Woodburn (Aquultic Argixerolls) soil series are strongly associated with fine-grained Missoula Flood deposits of units $\mathrm{Qff}_{1}$ and $\mathrm{Qff}_{2}$. Other common soil series on Missoula Flood deposits include Aloha (Aquic Xerocrepts), Dayton (Mollic Albaqualfs), and Holcomb (Mollic Albaqualfs). These are all fine, silty soils that show organic material accumulation and bioturbation, slight reddening of the underlying silt, and small amounts of pedogenic clay illuviation in the upper 1 to $1.5 \mathrm{~m}$.

Coarser-grained Missoula Flood deposits (Qfc) are primarily restricted to two fan-shaped sand, gravel, and boulder accumulations near Wilsonville and Canby that spread southward from low gaps at the head of the northern Willamette Valley. The Wilsonville fan originates from a low divide between the Tualatin Basin and the northern Willamette Valley along the path of Rock Creek (commonly referred to as the "Rock Creek gap"), and the Canby fan radiates from the southern end of the Oregon City gap, where 
the Willamette River has incised through the Columbia River Basalt Group (unit Tcr) and Boring Lava (unit QTb) at the Portland Hills structural zone at the northern margin of the northern Willamette Valley. A small deposit of Missoula Flood gravel also partly filled the valley of the Tualatin River near its confluence with the Willamette River at Oregon City. Bouldery gravel has been left in large longitudinal, delta, and eddy bars (O'Connor, 1993) in the lee of bedrock protrusions. These bars typically have smooth planar or convex surfaces that contrast with the ragged, "scabland" (Bretz, 1925) topography of nearby bedrock outcrops. These deposits have slightly finer equivalents south of the Willamette River, where flow through each of the gaps left several square kilometers of undulating surfaces near Canby underlain by bouldery, sandy gravel, locally capped by several meters of sand and silt. Characteristic are the sandy, gravelly soils of the Canderly (Ultic Haploxerolls) and Latourell (Ultic Haploxeralfs) series near Canby, and Willamette and Salem series soils near Wilsonville. In the Canby area, drillers' logs indicate that these deposits are locally 30 to $35 \mathrm{~m}$ thick and are found at altitudes as low as $10 \mathrm{~m}$ above sea level.

Stratigraphy and Sedimentology.-The total thickness of the main body of fine-grained flood deposits (unit $\mathrm{Qff}{ }_{2}$ ) locally exceeds $35 \mathrm{~m}$ in the central part of the northern Willamette Valley, but thins towards the basin margins and southward; in the southern Willamette Valley, deposits are everywhere thinner than $10 \mathrm{~m}$ (figs. 10 and 11; Allison, 1935, 1936, 1978; Glenn, 1965; Balster and Parsons, 1969; Gannett and Caldwell, 1998). The most complete exposures are along the Willamette River where lateral channel migration has created clean exposures of late Pleistocene and Holocene stratigraphy (figs. 9 and 10). Missoula Flood deposits typically overlie a soil developed in older deposits, including the post-Diamond Hill paleosol of Balster and Parsons (1969) on top of the 28- to 22-ka sand and gravel, but also conformably overlie unweathered fluvial sand and gravel within parts of the central portions of the northern and southern Willamette Valley (fig 10; Glenn, 1965). Little evidence of erosion is found where flood deposits directly overlie the paleosol developed on older sand and gravel, but in some areas the basal silt and sand beds are channeled into the underlying sand and gravel, partially or completely eroding the paleosol.

The bedded fine-grained flood deposits of unit Qff ${ }_{2}$ have three distinct internal characteristics: (1) almost all fresh exposures show remarkably rhythmic bedding under proper lighting and moisture conditions (fig. 9; Glenn, 1965; Allison, 1935, 1978; Waitt, 1985), (2) mineralogic analyses demonstrate that the sediment is of Columbia River Basin provenance rather than Willamette River Basin provenance (Glenn, 1965), and (3) the silt beds commonly contain outsized angular to subangular clasts of rock types foreign to the Willamette River Basin (Allison, 1935). These attributes are identical to those of equivalent fine-grained Missoula Flood deposits that have been found elsewhere along the Columbia River and its tributaries in Oregon, Washington, and western Idaho (Glenn, 1965; Baker, 1973; Allison, 1978; Waitt, 1980, 1985; Smith, 1993).

The internal stratigraphy, mineralogy, and grain size of unit $\mathrm{Qff}_{2}$ has been described in detail by Glenn (1965) for the northern Willamette Valley and is summarized and extrapolated to the entire study area as follows:

1. Individual beds within the sequence of finegrained Missoula Flood deposits range from less than $5 \mathrm{~cm}$ (centimeter) thick to about $1 \mathrm{~m}$, and are defined by subtle and gradational grain-size variations within each bed and locally distinct grain-size variations at contacts between beds.

2. The thickness and number of observable beds varies within the map area. At least 40 beds are countable in the central part of the northern Willamette Valley (Glenn, 1965, p. 88), but the number diminishes southward and towards the lowland margins. About 20 beds are readily distinguished at the Sidney section (fig. 9), and about 10 beds are visible at the Irish Bend section described by Allison (1978) in the southern Willamette Valley. At the extreme margins of deposition, such as the Cartney Park section (fig. 10), distinct beds are not visible, but can be felt when running a trowel or knife down the section because of subtle changes in grain size influencing the hardness of the deposit.

3. Where individual beds are discernible, they are generally thickest near midsection, and thin upsection toward the surface, where pedogenic processes have masked bedding of the upper meter or two. Commonly, the basal part of the unit does not have well-defined beds and their relative thickness is hard to evaluate. 
4. Some sections in the northern Willamette Valley contain scour-and-fill structures where multiple beds are unconformably inset within steep-sided channels cut into otherwise horizontally bedded deposits (Glenn, 1965).

5. Overall trends in grain size tend to vary directly with bed thickness. The thick middle beds tend to have slightly coarser materials, whereas lower beds, higher beds, and beds near the valley margins are typically finer.

6. Within individual beds, Glenn (1965) described grading as typically "normal," where each bed fines upwards, or "double," where beds are coarser in their central parts.

7. Silt and clay within individual beds is generally massive, but is locally laminated. Coarse silt and sand components are commonly laminated or cross-bedded between minor scour boundaries. Current directions indicated by bedding vary, but generally signal southward flow in the eastern part of the northern Willamette Valley, and northward flow in exposures along the modern Willamette River on the western margin of the northern Willamette Valley (Glenn, 1965).

Locally, the main body of Missoula Flood deposits (unit $\mathrm{Qff}_{2}$ ) is separated from the underlying paleosol by lacustrine(?) and fluvial silt, sand, and gravel of primarily Willamette River Basin provenance (figs. 1 and 10; Glenn, 1965; Balster and Parsons, 1969). This intervening unit-Unit II of Glenn (1965) in the northern Willamette Valley, and, presumably, the unexposed Wyatt Member of the Willamette Formation (described by Balster and Parsons [1969] in the southern Willamette Valley from inspection of shallow borings)—only is exposed in the northern Willamette Valley (fig. 10), where it is generally less than $4 \mathrm{~m}$ thick, and consists of gray, festoon cross-bedded sand and intercalated sandy silt lenses. Foresets and current ripples within the cross-bedded sand typically indicate downvalley (northward) flow. Upsection, the gray sand beds become thinner between intervening wavy silt lenses until there is an indistinct transition to the overlying, rhythmically bedded silts of Columbia River Basin provenance. Field identification of the contact between Willamette River Basin provenance gray sand and silt, and the overlying bedded silts of Columbia River provenance is difficult, but such a transition, generally corresponding to the zone sepa- rating predominantly sand from predominantly silt, corresponds to a gradual change between Willamette River Basin provenance and Columbia River Basin provenance (Glenn,1965, p. 75-87).

Fluvially reworked pumice and airfall tephra is exposed within Glenn's Unit II at the River Bend section (Appendix 2, Glenn, 1965, p. 83-84, Richard Waitt, U.S. Geological Survey, written commun., 1998). The reworked pumice grains match those collected from a similar stratigraphic position $16 \mathrm{~km}$ upstream at Wheatland Ferry (fig. 10) as well as a tephra that lies between the Wono $\left(27,300 \pm 300{ }^{14} \mathrm{C}\right.$ yr BP) and Trego Hot Springs (23,200 $\pm 200{ }^{14} \mathrm{C}$ yr BP) tephras in a core recovered from Tulelake, California (Appendix 2). The airfall tephra at River Bend does not match any known tephra layer.

Fine-grained Missoula Flood deposits of unit $\mathrm{Qff}_{2}$ are capped by a variety of thin deposits that are neither thick nor continuous enough to warrant mapping at this scale, but have been previously postulated to represent major regional Quaternary events (fig. 1). In the northern Willamette Valley, these deposits include the 0- to 30-cm of "gray pebbly silts" described by Glenn (1965, p. 87, 193), and in the southern Willamette Valley, the Greenback and Malpass Members of the Willamette Formation as defined by Balster and Parsons (1969). The gray pebbly silts of the northern Willamette Valley are massive, contain pebbles of exotic and local types, are thicker in swales, and are locally absent from topographic highs (Glenn, 1965). Likewise, the Greenback Member was described by Balster and Parsons (1969) as 0 to $1 \mathrm{~m}$ of light-gray silty material found at the surface of the southern Willamette Valley below altitudes of $120 \mathrm{~m}$. The Malpass Member of the Willamette Formation is 0 to $1 \mathrm{~m}$ of gray clay locally found between the Greenback Member and the bedded flood deposits below (Balster and Parsons, 1969), and where exposed at Irish Bend fills swales in the underlying flood deposits. At the Cartney Park section, bedded, erratic-bearing silts are capped by $2.5 \mathrm{~m}$ of massive to locally bedded darkgray silt and clay that contains thin, discontinuous layers of charcoal $\left(5,860 \pm 120{ }^{14} \mathrm{C}\right.$ yr BP; Appendix 3), and fluvially reworked and airfall Mazama pumice and ash (fig. 10).

No exposures of units Qff $_{1}$ or Qfc were examined in this study. Glenn (1965, p. 161-163) describes deposits exposed along the Willamette River that are possibly equivalent to unit $\mathrm{Qff}_{1}$ as "well stratified silts and sands" that are "...not horizontal but follow local relief in the underlying sediments." Allison (1978, 
p. 194-195) noted exposures of coarse-facies Missoula Flood deposits (unit Qfc), including "poorly sorted, bouldery rubble with south-slanting foresets" south of the Rock Creek gap near Wilsonville, and southwest-dipping foresets of poorly sorted gravel beds near Canby. Drillers' logs of unit Qfe near Canby and Wilsonville typically describe 15-35 $\mathrm{m}$ of boulders and gravel, locally capped with up to $5 \mathrm{~m}$ of sand and silt. drillers' logs of unit Qfe further away from the Rock Creek and Oregon City gaps typically describe up to $25 \mathrm{~m}$ of loose, sandy deposits.

Origin.-The bouldery fan deposits in the northern Willamette Valley (unit Qfc) and the main body of rhythmically bedded, Missoula Flood deposits (unit $\mathrm{Qff}_{2}$ ) are the product of multiple late Pleistocene cataclysmic floods from Glacial Lake Missoula (Glenn, 1965; Allison, 1978; Waitt, 1980, 1985; McDowell, 1991). Each bed within the fine-grained deposits probably represents an individual flood (Glenn, 1965; Allison, 1978; Waitt, 1980, 1985). As floods traveled down the Columbia River valley, a constriction downstream from Portland hydraulically impounded flow to as high as $150 \mathrm{~m}$ above sea level, resulting in water backflooding into the southern Portland and Tualatin Basins, from which it spilled southward into the Willamette Valley, primarily through the Oregon City and Rock Creek gaps. The south-dipping foresets in the bouldery fan deposits (unit Qfc) south of these gaps indicate high flow velocities directed southward, and the orientation of current structures in the main body of Missoula Flood deposits $\left(\mathrm{Qff}_{2}\right)$, indicate that a large, clockwise gyre was established in the northern Willamette Valley during many of these floods.

The largest flood(s) left deposits and ice-rafted erratics as far south as Eugene and up to an altitude of $122 \mathrm{~m}$ (Allison, 1935), although the number of floods that reached that stage is uncertain. About 10 separate beds at Irish Bend indicate that at least that many floods achieved a stage of at least $85 \mathrm{~m}$ above sea level, and at least 40 floods achieved a stage of at least $45 \mathrm{~m}$ above sea level at the River Bend section as described by Glenn (1965). The total number of floods that inundated the Willamette Valley cannot be deciphered accurately from exposures in the map area, but more complete stratigraphic records in eastern Washington indicate 60 to 90 late Pleistocene Missoula Floods (Atwater, 1986).

The stratigraphic and geomorphic position of unit Qff $_{1}$ lead us to infer that these deposits were laid down by later and smaller Missoula Floods than those that deposited the more extensive and higher deposits of unit $\mathrm{Qff}_{2}$. It is also likely that some of the deposits of unit Qff $_{1}$ were formed or reworked by the Willamette River as it reestablished itself within the silt blanketed lowlands of the northern Willamette Valley after the Missoula Floods that deposited unit Qff 2 . Glenn (1965, p. 161-163) states that the mineralogy of samples collected from the surface of unit $\mathrm{Qff}_{1}$ adjacent to the Willamette River between Newberg and Wilsonville "contain a heavy mineral suite similar to that found in other Willamette River floodplain samples."

Glenn (1965, p. 191-192) and Allison (1978) also proposed that there were two phases of flooding in the Willamette Valley; an early phase of multiple floods into a large lake recorded in the rhythmically bedded deposits of unit $\mathrm{Qff}_{2}$, and a later phase consisting of a single, climactic flood that scoured the gaps at the north end of the northern Willamette Valley and left the high-altitude erratics and thin pebbly silts and also deposited the lower-altitude fine-grained flood deposits of unit Qff ${ }_{1}$. Reckendorf (1993) modified this model, suggesting that the main body of fine-grained Missoula Flood deposits (unit $\mathrm{Qff}_{2}$ ) was from an earlier Pleistocene series of floods and that the thin pebbly silt capping the surfaces of unit $\mathrm{Qff}_{2}$ represented multiple late Pleistocene floods.

These scenarios involving a period of smaller floods followed by either single or multiple larger floods are inconsistent with stratigraphic and chronologic relations in the Willamette Valley and with observations elsewhere along the Missoula Flood route. The radiocarbon dates and tephrochronology of the underlying sand and gravel indicate that the Missoula Flood deposits in the Willamette Valley are younger than $22 \mathrm{ka}$. Because the floodbeds of unit Qff ${ }_{2}$ commonly overlie a paleosol, and there is no evidence of a regionally extensive lake either between the late Pleistocene sand and gravel of unit $\mathrm{Qg}_{2}$ and the bedded Missoula Flood deposits of unit $\mathrm{Qff}_{1}$, or within the bedded flood deposits themselves, it is most likely that each Missoula Flood inundated a largely subaerial landscape. (Local thin deposits of laminated silt and fine sand below the Missoula Flood deposits at the Wheatland Ferry and Weston Landing sections shown in figure 10 likely represent small floodplain lakes or ponds rather than an extensive water body.) The intervening sand and silt of local and transitional provenance observed below the bedded flood deposits of Columbia River Basin provenance along the Willamette River in the northern Willamette Valley may represent deposits of the pre-Missoula Flood Willamette River (Glenn, 1965) or, alterna- 
tively, may have been left by initial Missoula Floods that were relatively less laden with Columbia River Basin provenance sediment.

Local and regional evidence of the sequence of Missoula Floods is inconsistent with Glenn's (1965) and Allison's (1978) conclusion that the last Missoula Flood was the largest one. Evidence in eastern Washington (Atwater, 1986) and in the Columbia River Valley east of Portland (O'Connor and Waitt, 1996) shows that the last few Missoula Floods were much smaller than earlier floods. Indeed, stratigraphic relations in the Willamette Valley, where lower flood deposits (unit $\mathrm{Qff}_{1}$ ) are inset into higher deposits (unit $\mathrm{Qff}_{2}$ ), are identical to relations farther east in the Columbia River Valley, where lower deposits of bedded silts clearly postdate deposits of larger floods (O'Connor and Waitt, 1996). The massive gray pebbly silt that caps the main body of bedded flood deposits in the northern Willamette Valley, also attributed by Glenn (1965) and Allison (1978) to a climactic flood, is probably colluvium and loess, largely derived from reworking of Missoula Flood sediment. In the southern Willamette Valley, the capping Greenback and Malpass Clay members (fig. 1) of Balster and Parsons (1969) are probably a combination of loess and Willamette River Basin provenance fluvial deposits. This is clearly the case at the Cartney Park section, where the 7 ka Mazama tephra and a 5,860 $\pm 120{ }^{14} \mathrm{C}$ yr BP burned horizon within fluvial silt layers indicate Holocene overbank deposition on top of the finegrained Missoula Flood deposits (fig. 10). The observations that these capping units are generally thicker in swales but nowhere more than a few meters thick, contain sparse sedimentary structures, and at least locally are of Holocene age all point to a local origin rather than being deposited by an exceptionally large Missoula Flood.

Age.-Radiometric dates in the Willamette Valley and Portland Basin offer the following constraints on the age of the Missoula Flood deposits (units Qff ${ }_{1}$, $\mathrm{Qff}_{2}$, and Qfc):

1. Missoula Flood deposits in the Willamette Valley postdate the top of the paleosol at the Wheatland Ferry section from which we obtained an age of $22,060 \pm 100{ }^{14} \mathrm{C}$ yr BP age.

2. It is unlikely that there were Missoula Floods that inundated the Willamette Valley after the $12,240 \pm 330{ }^{14} \mathrm{C}$ yr BP age obtained by Glenn (1965) on peat that accumulated in a closed depression at the north end of the Rock Creek
Gap, or the $12,170 \pm 70{ }^{14} \mathrm{C}$ yr BP age obtained from North Fork Santiam River gravel that forms a surface inset against Missoula Flood deposits near Turner Gap.

3. Peat from a bog on Missoula Flood deposits in the northern Portland Basin at an altitude of $60 \mathrm{~m}$ above sea level has an age of 13,080 \pm $300{ }^{14} \mathrm{C}$ yr BP (Mullineaux and others, 1978). Any subsequent Missoula Floods in the Portland, or consequently Willamette River Basins, could not have achieved stages much greater than $60 \mathrm{~m}$ above sea level.

These age constraints are consistent with observations farther east that Missoula Floods occurred primarily between 15 and $12.7 \mathrm{ka}$ (Waitt 1980, 1985;

Atwater, 1986). Radiocarbon ages of 13,69 \pm 595 , $14,480 \pm 145$, and $14,795 \pm 150{ }^{14} \mathrm{C}$ yr BP obtained on organic material collected from high-level Missoula Flood deposits in the Columbia River valley east of Portland suggest that the larger floods may have been between 15 and $13.5 \mathrm{ka}$. (O'Connor and Waitt, 1996). Because the deposits of unit $\mathrm{Qff}_{1}$ are all lower than 60 $\mathrm{m}$ above sea level, it is possible that they postdate $13,080 \pm 300{ }^{14} \mathrm{C}$ yr BP

Hydrogeologic Considerations.-The Missoula Flood deposits and overlying loess and colluvium are largely included in the Willamette Silt hydrogeologic unit of Gannett and Caldwell, (1998). The main body of fine-grained Missoula Flood deposits (unit $\mathrm{Qff}_{2}$ ) is not used as a major water source; however, in the northern Willamette Valley sandy layers in Missoula Flood rhythmites and the sand unit between the paleosol and the rhythmites are capable of providing sufficient water for domestic use (Piper, 1942; Price, 1967a, b; Hampton, 1972). Where sand and silt at the base of the rhythmites is exposed, there is commonly seepage. Price (1967a, p. 28) reported that porosity of the Missoula Flood deposits in the northern Willamette Valley ranges from 41 to 47 percent, but that permeability is low. In the southern Willamette Valley, Missoula Flood deposits are too thin and fine-grained to serve as a ground-water source, although they probably permit recharge to the underlying Pleistocene sand and gravel.

An important exception to the overall low permeability of Missoula Flood deposits in the Willamette Valley are the two bouldery fans near Canby and Wilsonville. This area was called the "Canby fan" by Piper (1942, p. 42) and is included in Gannett and 
Caldwell's (1998) Willamette aquifer hydrogeologic unit. Many wells near Canby exploit up to $35 \mathrm{~m}$ of loose boulder gravel of "considerable water-yielding capacity” (Piper, 1942, p. 45).

\section{Holocene Floodplain Deposits of the Willamette River and Major Tributaries (Qalc)}

The Willamette River and its major tributaries have formed channels and floodplains of sand, silt, and gravel in swaths up to $6 \mathrm{~km}$ wide along valley and lowland bottoms. The Holocene floodplain and channel alluvium of the Willamette River and its major Cascade Range tributaries (unit Qalc) have been distinguished from Holocene alluvium of smaller streams (unit Qalf) because the channel and floodplain alluvium of the large rivers is distinctly coarser than sediment deposited by smaller Cascade Range and Coast Range tributaries and are likely to have significantly different hydrogeologic properties (Piper, 1942, p. 28). The following discussion pertains only to the deposits of the Willamette River and its major tributaries (unit Qalc).

Holocene deposits of the Willamette River and major tributaries partly include the "younger alluvium" of Piper (1942), "Recent alluvium" mapped by Allison (1953), "modern floodplain deposits" of Glenn (1965), "Recent river alluvium" and "Quaternary lower terrace deposits" of Bela (1979), and "Quaternary alluvium" of Beaulieu and others (1974). These deposits underlie the Horseshoe, Ingram, and Luckiamute geomorphic surfaces of Balster and Parsons (1968). Glenn (1965, p. 157-163) described stratigraphic and textural characteristics of floodplain deposits in the northern Willamette Valley, and Reckendorf (1973) reported on general geomorphic and soil characteristics of floodplains in the Willamette Valley.

Geomorphology.-The Willamette River has been channelized, deepened, and narrowed since European settlement (Klingeman, 1987; Benner and Sedell, 1997), but, prior to these modifications, the Willamette River in the southern Willamette Valley was anastomosing (as defined by Church, 1992) and had multiple anabranches of substantial flow at high discharges around semistable channel islands (Sedell and Froggatt, 1984). Annual formation of debris jams constantly reapportioned flow through the channel system (Benner and Sedell, 1997). In the northern Willamette Valley, the river has more of a meandering pattern (and fewer anabranches) that is constantly evolving through meander migration and cutoff formation. The major Cascade Range tributaries also typically have an overall meandering pattern formed by meander migration and cutoffs, in addition to shifting around low, midchannel islands and bars within short braided reaches.

The highest floodplain surfaces are about $15 \mathrm{~m}$ above typical summer river stages in the northern part of the valley, but become relatively lower farther upstream (fig. 12). Lower surfaces are found at various elevations above river level, but are not continuously traceable for great lengths along river valleys. Except for active channel beds and bars, most surfaces are covered by a variable thickness of fine sand, silt, and clay. Channel bed material diminishes in median size from $4.2 \mathrm{~cm}$ near Eugene to $1.9 \mathrm{~cm}$ at Willamette Falls (Klingeman, 1987). Maximum clast size on active bars diminishes from about $50 \mathrm{~cm}$ where the major tributary rivers enter the Willamette Valley to about $5 \mathrm{~cm}$ along the Willamette River near Newberg. Holocene floodplain surfaces are generally distinguished by their meander-scroll topography of arcuate ridges and swales (Reckendorf, 1973; Bela, 1979) that contrasts with the more planar topography of adjacent Pleistocene sand and gravel deposits and Missoula Flood sediment. Common soils on Holocene floodplain surfaces include the Camas, Newberg, Cloquato, Chapman, and Chehalis series, which are all Cumulic Ultic Haploxerolls or Fluventic Haploxerolls. Mapping of Holocene floodplain deposits largely followed Piper (1942), but precise placement of contacts was based on 7.5-minute topographic maps and NRCS soils maps.

Stratigraphy and Sedimentology.-Exposures created by recent bank erosion along the Willamette River reveal loose, openwork, imbricated gravel fining up to top strata of sand, silt, and clay that are commonly deposited in sequences that thin and fine upward (fig. 13). Long bank exposures show lateral facies variations such as gravelly channel facies grading to silty and sandy overbank facies. drillers' logs and river exposures along the Willamette River show that coarse channel deposits of sand and gravel are generally restricted to within $3 \mathrm{~m}$ above summer river stages; higher deposits are primarily overbank materials such as fine sand, silt, and clay. In the northern Willamette Valley, the overall composition of floodplain sediment is about evenly divided between sand, silt, and clay, but there is great variation from site to site (Glenn, 1965, p. 138-140).

Age.-Current floodplains are locally set into 12ka sand and gravel of unit $\mathrm{Qg}_{1}$ and 15- to 12.7-ka Mis- 


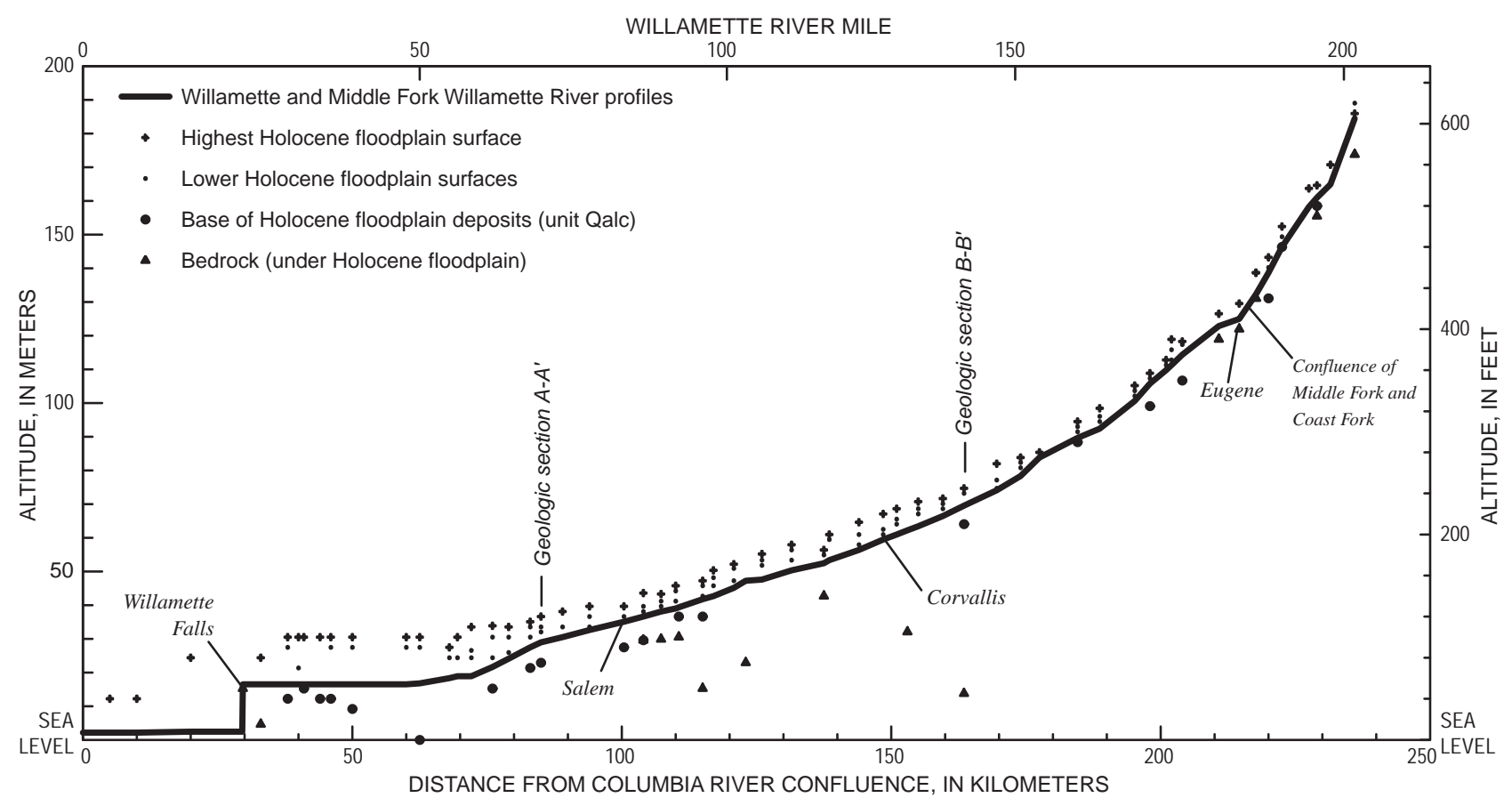

Figure 12. Positions of Holocene floodplain surfaces, the base of Holocene deposits, and bedrock beneath Holocene deposits. (Floodplain altitudes from U.S. Geological Survey topographic quadrangles. Bedrock altitudes from channel exposures and well logs. Bottom altitudes of the Holocene deposits are inferred from drillers' logs. Distance from the Columbia River confluence was measured along the general trend of the modern floodplain ["valley kilometer"] and does not directly correspond to river miles [see plate 1 for distance indicators].)

soula Flood deposits (units Qff , Qff $_{2}$, and Qfc) and, therefore, must be largely of Holocene age. Eleven radiocarbon ages collected from four exposures of floodplain sediment in the southern Willamette Valley all yielded ages less than $4 \mathrm{ka}$ (Appendix 3). There were no obvious exposures of 7-ka Mazama tephra seen during examination of most of the Willamette River between Harrisburg and Newberg, although likely Mazama tephra has been seen in a floodplain gravel pit near Albany (Edward Taylor, Oregon State University, oral commun., 1997), and within a channel fill of organic-rich clay exposed in a side channel in the northern Willamette Valley (Glenn, 1965, p. 161). Collectively, these observations indicate that the modern floodplains are formed of deposits laid down during at least the last 7,000 years, but most deposits near the present land surface and river course are younger than $4 \mathrm{ka}$.

Origin.-The morphology, stratigraphy, and chronology of floodplain sediment all imply lateral and vertical accretion of overbank and channel materials deposited by actively meandering and shifting rivers. Gravel and sand facies are from bedload transported along main channel bottoms and deposited in flanking bars. Sand, silt, and clay are primarily overbank deposits of suspended sediment. Finer deposits typically accumulate higher and further away from main flow paths. Older channel and bar deposits have gradually been covered by finer and finer deposits as channels migrated away or completely changed course to more distant paths. Floodplain surfaces of different relative elevations above the channel have likely had different histories of channel abandonment and subsequent accumulation of overbank deposits, and do not necessarily represent different river elevations, sediment regimes, or surface ages as postulated by Balster and Parsons (1968). Several large historic floods (notably 1861, 1890, 1943, 1964, 1996) have inundated all or most of the floodplain surfaces (Paula Minear, Oregon State University, written commun., 1998), and probably resulted in local aggradation on all floodplain levels. Collectively, the channel and floodplain morphology and stratigraphy, as well as historical accounts of channel mobility and "thick with mud" floods (Benner and Sedell, 1997), indicate meandering and anastomosing river systems with high suspended sediment loads (Church, 1992). The Holocene morphology and sediment transport characteristics of the Willamette River and major tributaries were clearly much different under natural 


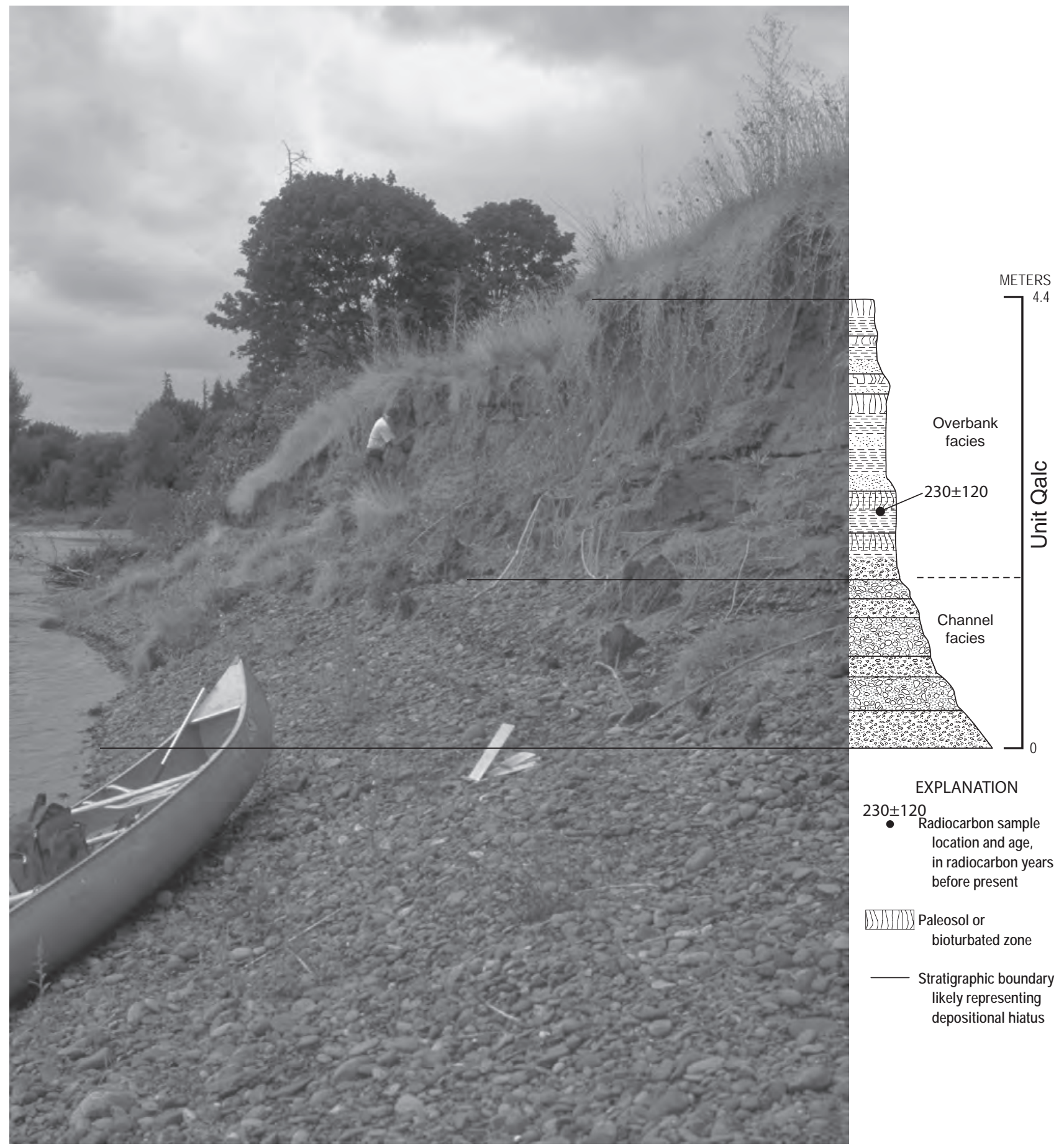

Figure 13. A measured stratigraphic section, and Holocene fluvial deposits exposed along the Willamette River at the southern end of Bear Island (river mile 140). (The view is southwest [upstream].)

conditions than the braided and bedload dominated streams of the late Pleistocene.

Hydrogeologic Considerations.-Holocene sand and gravel of the modern floodplains is a major source of ground water and is a component of the Willamette aquifer as defined by Gannett and Caldwell (1998). The Holocene sand and gravel typically has higher yields than other geologic units in the Willamette Valley (Piper, 1942, p. 27-28, 41-54). Woodward and others (1998, p. 29-35) present analyses showing that the Holocene floodplain deposits of the Willamette River and major tributaries have substantially larger values of specific capacity, hydraulic conductivity, and transmissivity than do underlying alluvial units of the 
Willamette aquifer (primarily units $\mathrm{Qg}_{1}$ and $\mathrm{Qg}_{2}$ ). As with the Pleistocene sand and gravel, the hydrogeologic properties of the Holocene sand and gravel are largely controlled by local and regional facies variations. These deposits are young enough, however, that postdepositional alteration and compaction are not important factors controlling hydrogeologic properties.

The arrangement of permeable and low-permeability materials appears to be markedly different for Holocene floodplain deposits than for the Pleistocene sand and gravel. Drillers' logs and bank exposures show that the meandering and anastomosing rivers of the Holocene have left tortuous ribbons of well-sorted gravel and sand separated horizontally and vertically by fine-grained overbank deposits. Similar to current river dimensions, the coarse-grained channel facies in the subsurface are typically several tens of meters wide, and 1 to $3 \mathrm{~m}$ thick. Overbank deposits of silt, clay, and minor sand typically underlie much of the floodplain and may restrict ground-water flow between individual ribbons of coarse-grained channel facies deposits. Grain size within channel-facies deposits diminishes downstream, from cobbles and gravel within the major tributary valleys and where tributaries emerge from the Cascade Range foothills, to sand and gravel in more distal portions of the Willamette lowlands. Nevertheless, the channel facies are everywhere well-sorted, loose, and likely to be highly permeable.

On a basinwide scale, Holocene sand and gravel deposited by the Willamette River and its major tributaries can probably be considered a homogenous unit for most ground-water analysis purposes (see, for example, Piper, 1942, p. 45). At floodplain-width scales, however, the bimodal arrangement of channel and overbank facies probably creates highly variable permeabilities. At these more local scales, facies variations between and within channel and overbank deposits likely control ground-water flow patterns, influencing processes such as solute transport, hyporheic flow, and interactions between surface water and ground water. Locations where subsurface channel facies intersect current river channels are likely to be zones of substantial exchange between ground water and surface water.

\section{Other Quaternary Map Units}

Three other units of Quaternary age have been distinguished in the map area. These units are generally of small extent and of uncertain or broad ages, and have not been studied closely.

Basin Fill (Qbf).—Along the lowland margins are small basins and areas that have accumulated clay, silt, sand and minor gravel from the adjacent hillslopes and small drainages. In the southern Willamette Valley, these areas include numerous small basins along the western and eastern margins of the Willamette lowlands, as well as higher parts of the valley floor that lie between the Coast and Cascade Range foothills and the broad braidplains of coarse-grained deposits left by the major rivers. There are also several small basins in the Cascade Range foothills between Lebanon and Stayton that have been partly filled with fine-grained deposits from local drainages. There are no basin-fill deposits mapped in the many morphologically similar basins in the northern Willamette Valley, because these basins are all blanketed by mappable thicknesses of fine-grained Missoula Flood deposits (unit $\mathrm{Qff}_{2}$ ). The basin-fill deposits of unit $\mathrm{Qbf}$ have been variously mapped by previous workers, but are largely a component of the "older alluvium" of Piper (1942) and underlie parts of the Luckiamute, Ingram, Winkle, Senecal and Calapooyia geomorphic surfaces of Balster and Parsons (1968). Surfaces formed in basin-fill deposits typically have clayey montmorillonitic soils of the Bashaw (Typic Pelloxererts), Natroy (Aquic Chromoxererts), Dayton (Typic Albaqualfs), and Awbrig (Vertic Albaqualfs) soil series (Knezevich, 1975; Langridge, 1987; Patching, 1987). Mapping criteria were primarily topography and soils.

Basin-fill deposits were not systematically examined for this study, but their planar surfaces and geomorphic positions indicate that they are composed of fine-grained alluvium derived from adjacent hillslopes and drainages that head in the western Cascade Range and the Coast Range. Piper (1942, p. 28) described some of these deposits as "heterogeneous material that is largely earthy." The locations and geomorphic positions of the basin-fill deposits also indicate regional aggradation of extensive portions of the Willamette lowland after a period of regional base level substantially below the present valley floor. Likewise, the basin-fill deposits along the margins of Willamette lowlands in the southern Willamette Valley, including along the Long Tom River and adjacent to the Cascade Range foothills north of Springfield, appear to fill marginal topographic lows created by extensive deposition of coarse-grained deposits in the central axis of the southern Willamette Valley from the McKenzie and Willamette Rivers. Similar deposits are likely 
extensive in the subsurface along the margins of the northern and southern parts of the Willamette Valley, composing a part of the Willamette confining hydrogeologic unit of Gannett and Caldwell (1998), but have been mostly covered by fine-grained Missoula Flood deposits of unit $\mathrm{Qff}_{2}$.

Landslide Deposits (Qls).- Many slopes of the Cascade Range foothills are covered with thick deposits of landslide debris and colluvium. These deposits were not systematically mapped for this study, but their distribution is reproduced with slight modification from the geologic compilation of Walker and McLeod (1991). Local modifications to the extent of landslide deposits mapped by Walker and McLeod (1991) were made on the basis of deposit expression on 7.5-minute topographic maps. An additional large landslide deposit was identified at the juncture between the Willamette Valley and the Cascade Range east of Harrisburg, and a thick mantle of colluvium on the Cascade Range foothills east of Salem is mapped as unit Qls where it obscures the underlying bedrock geology.

\section{Undifferentiated Alluvium (Qau).-Alluvial}

deposits in small tributary valleys in the uplands surrounding the Willamette Valley and outside of the limits of fine-grained Missoula Flood deposits (unit Qff ${ }_{2}$ ) have not been differentiated with respect to age or sedimentology as part of this study. Also undifferentiated are the Holocene and Pleistocene deposits of the major tributaries in their upper reaches within the map area (primarily above the reservoirs). The distribution and extent of unit Qau was defined on the basis of topography. The distinction from basin-fill deposits (unit Qbf) is locally arbitrary, but unit Qau was primarily mapped in narrow valleys rather than wide, flat-bottomed basins and valleys. Unit Qau was mapped only outside the limits of Missoula Flood deposits, where finegrained deposits of the smaller tributaries (unit Qalf) that postdate the 15-12.7 ka Missoula Floods cannot be readily distinguished from older tributary deposits.

\section{THICKNESS AND EXTENT OF QUATERNARY DEPOSITS}

A primary aim of the Willamette Ground-Water Study is to develop a numerical ground-water model for the Willamette Valley to simulate effects of management scenarios on ground-water flow. To accurately simulate ground-water flow, understanding of the distribution and thickness of hydrogeologic units is required. Gannett and Caldwell (1998) described the distribution and thickness of the "Willamette aquifer," a coarse-grained basin-fill unit, which includes the Quaternary units QTt, QTg, $\mathrm{Qg}_{2}, \mathrm{Qg}_{1}$, Qfc, and Qalc defined in this report (fig. 2). Many of these Quaternary units within the Willamette aquifer have distinctly different hydrogeologic properties due to (1) grain-size characteristics, (2) degree of weathering, compaction, and cementation, and (3) internal facies architecture. For example, Woodward and others (1998, p. 52) noted that the coarse-grained deposits in the floodplains of the Willamette River and major tributaries (largely corresponding to unit Qalc) were more permeable than the rest of the Willamette aquifer.

Of the Quaternary geologic units defined in this study, we judge that two units of regional extent are likely to be generally more permeable than other Quaternary units and we have further evaluated their subsurface extent and thickness. The Holocene floodplain deposits of the Willamette River and major tributaries (unit Qalc) have been identified by Piper (1942) and Woodward and others (1998) as having the greatest permeability within the Willamette Valley. In our analysis of the thickness of unit Qalc, we have only considered the sand and gravel facies, assuming that the several meters of overlying sand, silt, and clay overbank deposits are much less permeable and perhaps above the regional water table. We also infer that the Pleistocene sand and gravel that postdates the Missoula Floods (unit $\mathrm{Qg}_{1}$ ) is more permeable than older Quaternary units because it is generally looser and less cemented than older units. Similar to our analysis of unit Qalc, we have estimated the thickness of the sand and gravel component of unit $\mathrm{Qg}_{1}$, excluding the approximately 1 to $2 \mathrm{~m}$ of silt and clay that generally caps the sandy gravel at surface exposures.

\section{Methods}

Generalized estimates of the thickness of unit $\mathrm{Qg}_{1}$ and the sand and gravel facies of unit Qalc for the map area were produced by extrapolating positions of contacts exposed in gravel pits and along riverbanks to the rest of the study area on the basis of descriptions of subsurface conditions from drillers' logs. The procedure used was as follows:

1. A series of 29 geologic sections (see, for example, fig. 3) was drawn perpendicular to the trends of the surface exposures of the postMissoula Flood Pleistocene sand and gravel (unit $\mathrm{Qg}_{1}$ ) and the Holocene floodplain deposits (unit Qalc). Geologic sections were located 
on the basis of proximity to exposures, availability of drillers' logs, and spacing. Along the trend of the Willamette River and tributary river floodplains, geologic sections were drawn about every $15 \mathrm{~km}$.

2. Subsurface geology for each geologic section was locally interpreted from riverbank and gravel pit exposures, but more generally derived from about 850 lithologic logs of water wells, oil and natural gas wells, and geotechnical borings. Approximately one-half of these logs are from field-located wells included in USGS and Oregon Water Resources Department databases used to support recent (Woodward and others, 1998; Gannett and Caldwell, 1998) and ongoing (Orzol and others, 2000) studies of Willamette Basin ground-water conditions. Information from field-located wells was further supplemented by drillers' logs from State of Oregon Water Well Reports maintained in the USGS Oregon District office in Portland, Oregon. These wells have not been precisely located by USGS personnel, but were located by the driller to the quarter section $\left(0.65 \mathrm{~km}^{2}\right)$ and street address. Records of wells that were clearly incorrectly located by the driller were not used. Locations of wells not precisely on the trace of the geologic section were projected to the section trace on the basis of topographic position and the geologic unit in which the well is located. If either the topographic position or the surficial geologic unit at the well location was not clear from the available location information, the record was not used in constructing the geologic section. Because the upper Quaternary units are generally flat-lying, errors due to uncertain location and imprecise projection are probably small.

3. For each geologic section, the tops and bottoms of the sand and gravel facies of units $\mathrm{Qg}_{1}$ and Qalc were interpreted from stratigraphic exposures and projected drillers' logs. For most of the geologic sections, there is little direct stratigraphic information on the bottoms of units $\mathrm{Qg}_{1}$ and Qalc and there was consequently large reliance on drillers' notes of sedimentary characteristics. The base of the sand and gravel facies of unit Qalc was inferred to correspond to the transition between zones typically described by well drillers as "clean sand and gravel," or "gravel with sand (or silt) layers" and underlying zones of "hard" or "compact" sandy gravel. The top of sand and gravel facies of units Qalc and $\mathrm{Qg}_{1}$ was identified from drillers' notes of transitions between sand and gravel and overlying silt and clay. The thickness of the Pleistocene sand and gravel that postdates the Missoula Floods (unit $\mathrm{Qg}_{1}$ ) was estimated for locations where it forms the surface exposures, and for where it was assumed to exist below the Holocene floodplain deposits of unit Qalc. Where unit $\operatorname{Qg}_{1}$ was inferred to be present below unit Qalc, the top of unit $\mathrm{Qg}_{1}$ was inferred to be equivalent to the base of unit Qalc (as depicted in figs. 3, geologic sections $\mathrm{A}-\mathrm{A}^{\prime}$ and $\left.\mathrm{B}-\mathrm{B}^{\prime}\right)$. The base of unit $\mathrm{Qg}_{1}$ was inferred to correspond to drillers' records of a transition to underlying zones of "cemented sand and gravel," which likely corresponds to the older, pre-Missoula Flood, Pleistocene sand and gravel of unit $\mathrm{Qg}_{2}$.

4. For each of the 29 geologic sections, representative altitudes were chosen for:

(a) the top and bottom of the sand and gravel facies of unit $\mathrm{Qg}_{1}$ under surface exposures of $\mathrm{Qg}_{1}$ (where the top the sand and gravel is generally 1 to $2 \mathrm{~m}$ below the terrace surface);

(b) the top and bottom of unit $\mathrm{Qg}_{1}$ under surface exposures of unit Qalc (where the top of unit $\mathrm{Qg}_{1}$ corresponds to the bottom of Qalc); and,

(c) the top and bottom of the sand and gravel facies of unit Qalc.

5. The altitudes of the tops and bottoms of the sand and gravel facies for units Qalc and $\mathrm{Qg}_{1}$ determined from these geologic sections were plotted along valley profiles for the Willamette, Molalla, North Fork Santiam, South Fork Santiam, McKenzie, Middle Fork Willamette, and Coast Fork Willamette Rivers, as well as for the late Pleistocene routes of the North Fork Santiam River between Stayton and Salem through Turner Gap and the South Fork Santiam River between Lebanon and Albany. Data from geologic sections and topography was supplemented by field observations of stratigraphy along channel banks 
and gravel pits, and by interpretation of additional drillers' logs to fill gaps in the profiles.

6. Smooth curves encompassing the observed and inferred altitudes for the tops and bottoms of the units were drawn parallel to river and terrace profiles to provide estimates along valley trends for the (1) top and bottom of sand and gravel facies of unit $\mathrm{Qg}_{1}$ under surface exposures of $\mathrm{Qg}_{1}$, (2) top and bottom of unit $\mathrm{Qg}_{1}$ under surface exposures of Qalc, and (3) top and bottom of sand and gravel facies of unit Qalc. River and terrace profiles were used as a guide to estimate thickness because the present- and paleo-river grades defined by the river and terrace profiles are likely similar to the river grades during the times when the rivers were at altitudes corresponding to the bottoms of units Qalc and $\mathrm{Qg}_{1}$, thus aiding in extrapolation between widely spaced constraints on the tops and bottoms of the units.

7. From these curves, altitude contours for the tops and bottoms of each unit were drawn and digitized into a geographic information system. These contours were drawn normal to overall valley trends (parallel to cross sections); thus, there was no information carried forward regarding cross-valley trends in the tops and bottoms each unit. In general, our inference from inspection of drillers' logs is that at the scale of the several-kilometer-wide floodplains, lateral variations in the thickness of these units are small relative to their lateral extent.

8. Within a geographic information system, surfaces were generated to fit the contours representing the altitudes of the tops and bottoms of each unit, from which unit thickness was calculated. For some small and isolated areas of unit $\mathrm{Qg}_{1}$, where thickness could not be objectively defined by drillers' logs or by the generated surfaces, thickness values were assigned on the basis of the estimated unit thickness of nearby areas of unit $\mathrm{Qg}_{1}$.

\section{Results}

This analysis process resulted in regional estimates of the thickness of units Qalc and $\mathrm{Qg}_{1}$. In evaluating the results, however, we emphasize that the thickness estimates were derived from widely scattered exposures and interpretation of sometimes imprecise drillers' logs. Consequently, the resulting thickness maps (figs. 14 and 15) only portray highly generalized patterns in unit thickness and should not be used for site-specific estimates of the thickness of either unit Qalc or $\operatorname{Qg}_{1}$. Nevertheless, at a broader scale that is appropriate for incorporating into regional ground-water flow models, these thickness estimates do show regional variations in the thickness of highly permeable components of the Willamette aquifer.

\section{Thickness of Sand and Gravel Facies of Holocene Floodplain Deposits (Qalc)}

The thickness of the sand and gravel facies of the Holocene floodplain deposits is everywhere less than $15 \mathrm{~m}$ (fig. 14). Holocene sand and gravel is generally thickest under the Willamette River floodplain in the northern Willamette Valley, where it is typically 5 to $10 \mathrm{~m}$ thick, but is nearly $15 \mathrm{~m}$ thick near Salem. Along the Willamette River floodplain in the southern Willamette Valley, Holocene sand and gravel is typically less than $5 \mathrm{~m}$ thick, and is thin or absent where the Willamette River flows on or near bedrock near Eugene. Within the major tributary valleys, the Holocene sand and gravel is generally less than $10 \mathrm{~m}$ thick.

Estimates of the thickness and extent for the Holocene floodplain deposits could be improved with additional information on the distribution and chronology of subsurface deposits. Nevertheless, the distinct difference in the morphology, sedimentology, and facies architecture between the meandering river deposits of the Holocene and the underlying and adjacent deposits of the braided stream systems of the Pleistocene channel is helpful in making these thickness and extent estimates, especially for the floodplain of the Willamette River where the distinction between Pleistocene and Holocene river pattern is most pronounced. In major tributary valleys, however, many reaches of the present rivers are transitional between braided and meandering patterns, and it is more difficult to separate Holocene from Pleistocene deposits solely on the basis of morphology and sedimentology.

\section{Thickness of Pleistocene Sand and Gravel that Postdates the Missoula Floods $\left(\mathbf{Q g}_{1}\right)$}

The post-Missoula Flood Pleistocene sand and gravel (unit $\mathrm{Qg}_{1}$ ) is generally less than $20 \mathrm{~m}$ thick (fig. 15). For portions of the Willamette lowlands 


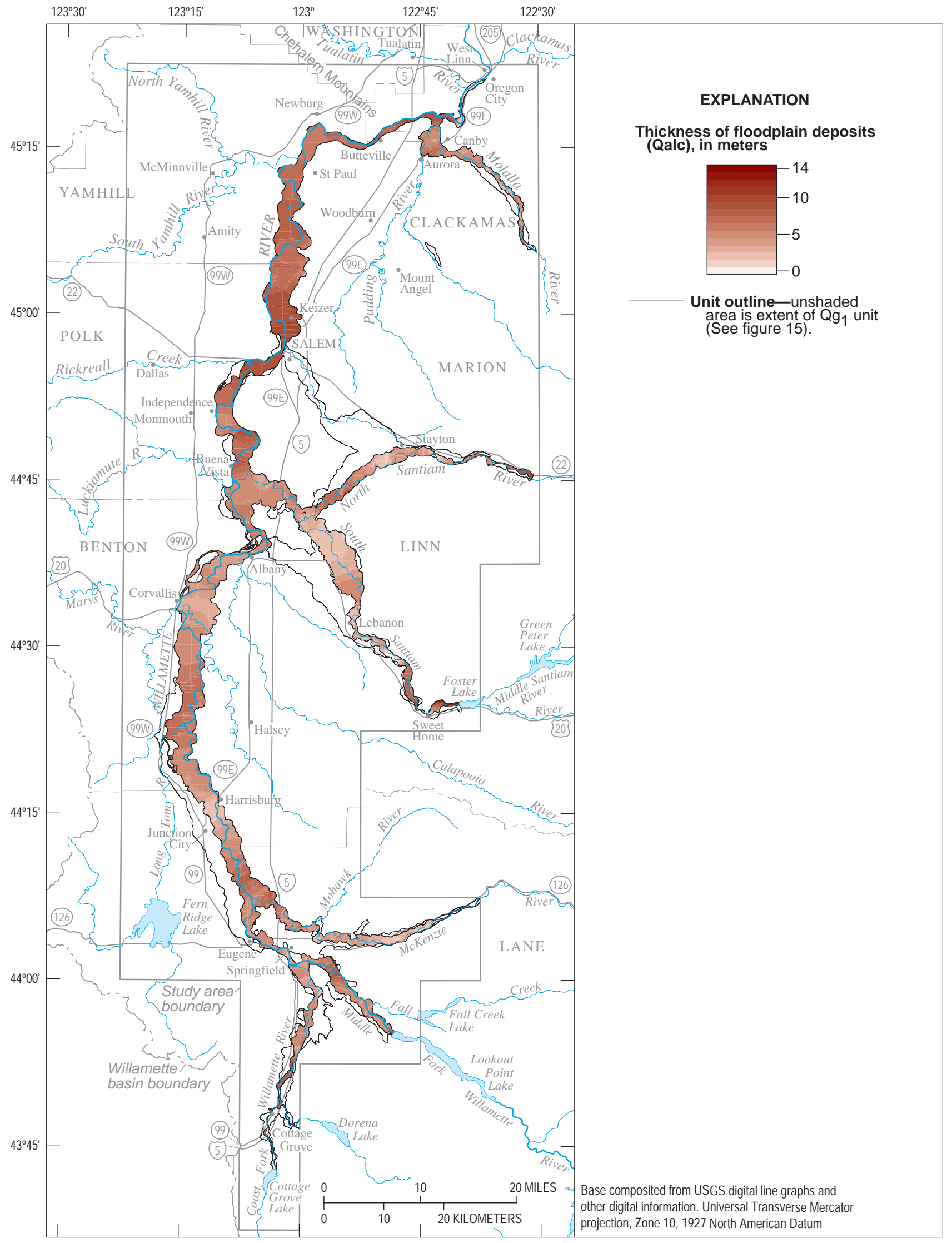

Figure 14. Approximate thickness of the sand and gravel (channel) facies of Holocene floodplain deposits (unit Qalc) of the Willamette River and major tributaries. (See text for discussion of methods and uncertainties). 


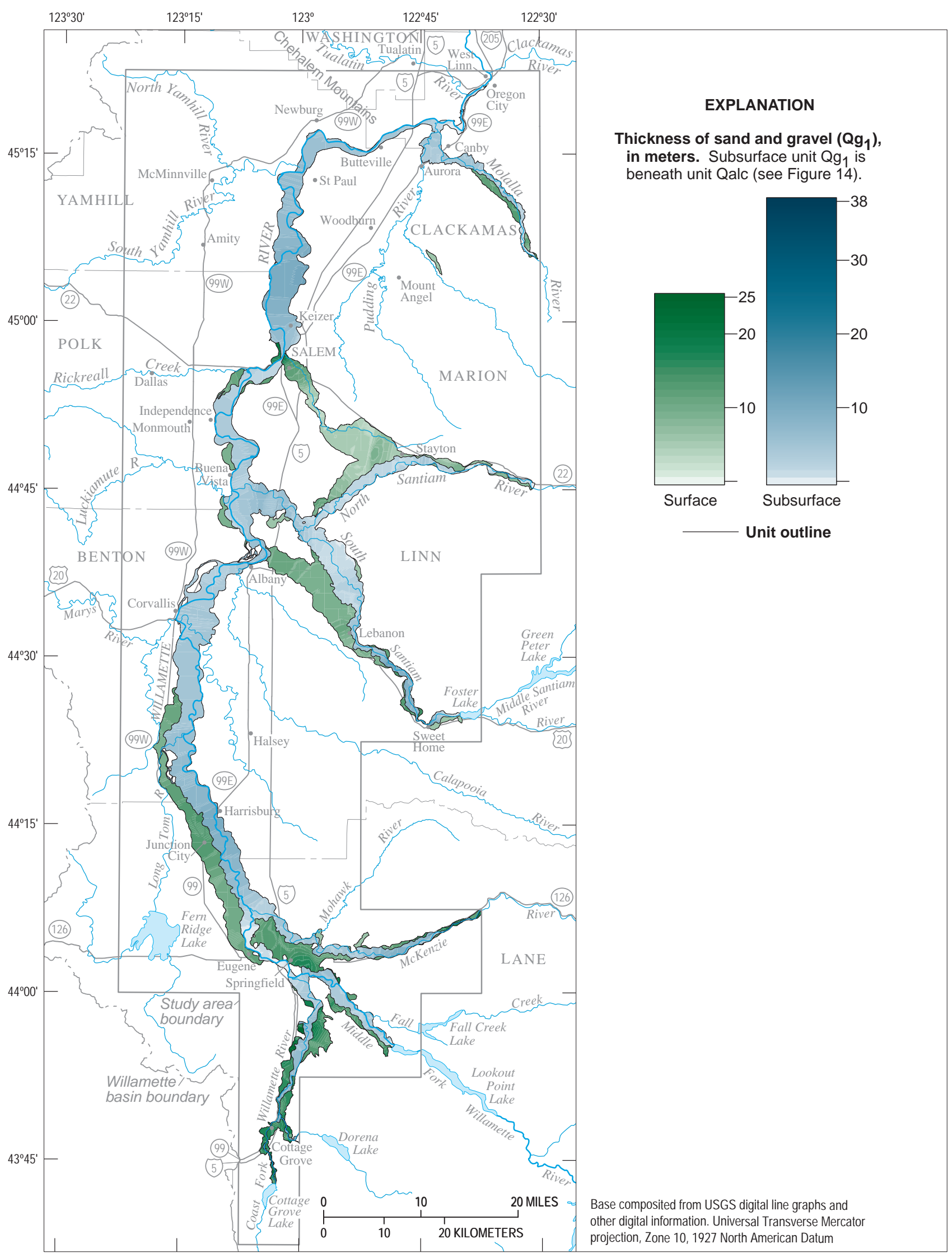

Figure 15. Approximate thickness of the Pleistocene sand and gravel that postdates the Missoula Floods (unit $\mathrm{Qg}_{1}$ ). (The thickness estimates were calculated separately for [1] areas where unit $\mathrm{Qg}_{1}$ is exposed at the surface and [2] where it is inferred to be present, but generally thinner, in the subsurface under the Holocene floodplain deposits of unit Qalc. See plate 1 for distribution of surface exposures of units $\mathrm{Qg}_{1}$ and Qalc.) 
along the Willamette River where unit $\mathrm{Qg}_{1}$ is exposed at the surface, unit $\mathrm{Qg}_{1}$ is typically 10 to $15 \mathrm{~m}$ thick. Under $\mathrm{Qg}_{1}$ surfaces flanking the major tributaries, we judge unit $\mathrm{Qg}_{1}$ to be mostly 5 to $20 \mathrm{~m}$ thick; the unit appears to be thickest in the McKenzie, Middle Fork Willamette, and Coast Fork Willamette River Valleys, where unit $\mathrm{Qg}_{1}$ is typically between 10 and $20 \mathrm{~m}$ thick, but locally may be as thick as $35 \mathrm{~m}$. Along the temporary post-Missoula Flood route of the North Fork Santiam between Stayton and Salem through Turner Gap, unit $\mathrm{Qg}_{1}$ is 3 to $15 \mathrm{~m}$ thick; and for the similarly temporary route of the South Fork Santiam between Albany and Lebanon, unit $\mathrm{Qg}_{1}$ is approximately 10 to $15 \mathrm{~m}$ thick. Under the Holocene floodplain deposits of unit Qalc, unit $\mathrm{Qg}_{1}$ is generally less than $15 \mathrm{~m}$, and in many places is absent or very thin because of Holocene erosion or reworking (see, for example, fig. 3, geologic section $\mathrm{C}-\mathrm{C}$ ').

The thickness and extent information for the Pleistocene sand and gravel deposited after the Missoula Floods is less certain than for the sand and gravel facies of the Holocene floodplain deposits (Qalc). The extent of unit $\mathrm{Qg}_{1}$ and its differentiation from older sand and gravel deposited before the Missoula Floods (unit $\mathrm{Qg}_{2}$ ) is clear at altitudes below about $120 \mathrm{~m}$ above sea level, where the presence or absence of a cover of fine-grained Missoula Flood deposits (units $\mathrm{Qff}_{1}$ and $\mathrm{Qff}_{2}$ ) provides sure evidence of the age of the deposits relative to the Missoula Floods. But above 120 m, where Missoula Flood deposits are absent and the age of deposits is less certain, the extent of unit $\mathrm{Qg}_{1}$ is less easily determined. Consequently, for most of the major tributary valleys and for some areas of higher altitude in the southern Willamette Valley, the distribution of Pleistocene sand and gravel deposited after the Missoula Floods (unit $\mathrm{Qg}_{1}$ ) is much more tentatively mapped on the basis of relative elevation and soil and weathering characteristics. Determining the thickness of unit $\mathrm{Qg}_{1}$ is also difficult because subsurface boundaries between units $\mathrm{Qg}_{1}$ and $\mathrm{Qg}_{2}$ are subtle, and are generally only clear in large exposures where it is locally defined by a subplanar layer of cobbles or boulders that separates oxidized and consolidated gravel below from gray, loose, openwork gravel above. Most drillers' reports fail to document this transition, and in many areas the estimated thickness of unit $\mathrm{Qg}_{1}$, shown in figure 15, likely includes upper zones of older sand and gravel deposits. Thickness values for unit $\mathrm{Qg}_{1}$ along the Coast Fork Willamette River are the most tentative because of the difficulty in discriminating between units $\mathrm{Qg}_{1}$ and $\mathrm{Qg}_{2}$ on the sur- face and in the subsurface, fewer available drillers' logs, and the generally finer texture of Coast Fork deposits. Despite these local and regional uncertainties, the overall thickness and extent information portrayed for unit $\mathrm{Qg}_{1}$ in figure 15 represents a less consolidated portion of the Pleistocene sand and gravel component of the Willamette aquifer that is likely to have hydrogeologic properties slightly different than the more compacted and cemented sand and gravel below.

\section{SUMMARY AND CONCLUSIONS}

The lowlands and tributary valleys of the Willamette Valley are underlain by five major sedimentary units of Quaternary age that each record major geologic and environmental episodes. The character, distribution, and thickness of these deposits also exert substantial control on current topography, soil characteristics, and ground-water properties.

The oldest widespread unconsolidated deposits are fluvial sands and gravels (unit QTg) that underlie terraces flanking lowland margins and tributary valleys. These deeply weathered sands and gravels are not well dated, but were probably mostly deposited between 2.5 and $0.5 \mathrm{Ma}$. The sand and gravel deposits likely record climatic events affecting sediment supply in the Cascade and Coast Ranges, but the present positions of terrace surfaces undoubtedly reflect postdepositional tectonic deformation-either direct tectonic uplift of terrace and piedmont surfaces, or regional tectonic controls on local base level.

The weathered terrace gravels have been isolated from subsequent deposition by basin margin uplift, channel lowering, or tectonic depression of the main Willamette lowlands, which in turn has accommodated as much as $500 \mathrm{~m}$ of Tertiary and Quaternary lacustrine and fluvial fill that now underlies the main valley and lowland floors. Within the lowlands, the upper 10 to $50 \mathrm{~m}$ of fill is primarily Quaternary sand and gravel (units $\mathrm{Qg}_{1}$ and $\mathrm{Qg}_{2}$ ) deposited primarily by braided channel systems in subhorizontal sheets 2 to $10 \mathrm{~m}$ thick. These deposits grade to fans up to $100 \mathrm{~m}$ thick where major Cascade Range rivers enter the lowlands, and are traced farther upstream as much thinner valley trains of coarse gravel flanking the major Cascade Range tributaries. Contained within Pleistocene sand and gravel deposits are 0.04-0.10 Ma lahar deposits from Mount Jefferson and a 0.42-Ma lahar 
deposit from an unknown source in the headwaters of the McKenzie or Middle Fork Willamette Rivers.

These ages indicate that sand and gravel deposition in the Willamette Valley spans at least the last $0.4 \mathrm{Ma}$.

These Pleistocene sand and gravel deposits are a major source of ground water, and their hydrogeologic properties are controlled primarily by lateral facies variations within broadly time-equivalent sheets of sand and gravel, and secondarily by the increased compaction and cementation of deeper and older deposits. The two most recent pulses of deposition culminated about 23 and $12 \mathrm{ka}$, producing two mappable units (units $\mathrm{Qg}_{2}$ and $\mathrm{Qg}_{1}$, respectively) for which the uppermost deposits represent episodes of greater sediment production from the Cascade Range during cooler climates of the late Pleistocene.

The latest Pleistocene sand and gravel of unit $\mathrm{Qg}_{1}$, which was deposited at about $12 \mathrm{ka}$ and subsequent to the Missoula Floods, is likely to be the most permeable of the Pleistocene sand and gravel deposits because it is the least cemented and weathered. This unit was deposited in broad swaths following the Willamette River and major tributaries, as well as along temporary routes of the North Fork Santiam River between Stayton and Salem through Turner Gap, and the South Fork Santiam River between Lebanon and Albany. To support numerical simulation of the ground-water flow system that is being conducted as part of the U.S. Geological Survey's Willamette Ground-Water Study, the thickness of the post-Missoula Flood sand and gravel unit was estimated from stratigraphic exposures and drillers' logs. Although it was locally difficult to differentiate this unit in the subsurface from older Pleistocene sand and gravel, in most locations unit $\mathrm{Qg}_{1}$ is inferred to be between 5 and $20 \mathrm{~m}$ thick (fig. 15). The unit is seemingly thickest in the McKenzie, Middle Fork Willamette, and Coast Fork Willamette River Valleys, where unit $\mathrm{Qg}_{1}$ is typically between 10 and $20 \mathrm{~m}$ thick, but locally may be as thick as $35 \mathrm{~m}$.

After $12 \mathrm{ka}$, there was a profound change in sediment and flow regimes of the Willamette River and its major tributaries: the Pleistocene braided river systems that formed vast braidplains of sand and gravel evolved to incised and meandering rivers that are constructing today's near-channel gravel bars and flanking sand- and silt-mantled floodplains (mapped together as unit Qalc). Modern floodplains are typically 3 to 6 $\mathrm{km}$ wide, are covered by cumulic soils, and have been flooded several times during the past two centuries (Brands, 1947). Underlying the silt and sand cover of the Holocene floodplains are sequences of channel facies that form belts of highly permeable sand and gravel separated by overbank facies of less permeable fine sand, silt, and clay. The ages of most Holocene deposits presently exposed along the Willamette River are less than $4 \mathrm{ka}$, although deposits at depth and further away from the present channel are locally older than $7 \mathrm{ka}$.

The Holocene channel and floodplain deposits of unit Qalc are the most permeable of the regionally extensive Quaternary units. Similar to the latest Pleistocene sand and gravel of unit $\mathrm{Qg}_{1}$, the thickness of coarse facies of the Holocene sand and gravel (unit Qalc) was estimated to aid in numerical modeling of regional ground-water flow conditions. Almost everywhere, the sand and gravel facies of the Holocene floodplain deposits are less than $15 \mathrm{~m}$ (fig. 14). Holocene sand and gravel is generally thickest in the northern Willamette Valley, where it is typically 5 to $10 \mathrm{~m}$ thick, but might be as thick as $15 \mathrm{~m}$ near Salem. In the southern Willamette Valley and along the major tributaries, Holocene sand and gravel is generally thinner than 5 to $10 \mathrm{~m}$.

Between 15 and $12.7 \mathrm{ka}$, fluvial processes of the Willamette River and its Cascade and Coast Range tributaries were repeatedly and cataclysmically interrupted by multiple floods from Glacial Lake Missoula. These floods locally left over 40 beds of sand, silt, and clay derived primarily from the upper Columbia River Basin. Total thickness of the fine-grained Missoula Flood deposits (units $\mathrm{Qff}_{2}$ and $\mathrm{Qff}_{1}$ ) locally exceeds $35 \mathrm{~m}$ at lower altitudes in the northern Willamette Valley, but tapers to a thin veneer at altitudes of 100 to $120 \mathrm{~m}$ above sea level along the margins of the northern Willamette Valley and on the margins and higher plains in the southern Willamette Valley. The Missoula Floods also left two bouldery gravel fans (unit Qfc) where strong currents entered the northern Willamette Valley through low divides from the north. Missoula Flood sediment is only a minor ground-water source except for the bouldery fans at the northern end of the study area, but the silts and clays left behind by the floods form the fertile substrate that supports Willamette Valley agriculture. 


\section{REFERENCES}

Allison, I.S., 1935, Glacial erratics in Willamette Valley: Geological Society of America Bulletin, v. 46, p. 675-722.

1936, Pleistocene alluvial stages in northwestern Oregon: Science, v. 83, p. 441-443.

-I.S., 1953, Geology of the Albany quadrangle, Oregon: Oregon Department of Geology and Mineral Industries Bulletin 37, 18 p.

1978, Late Pleistocene sediments and floods in the Willamette Valley: The Ore Bin, v. 40, p. 177-191 and 192-202.

Allison, I.S., and Felts, W.M., 1956, Reconnaissance geologic map of the Lebanon quadrangle, Oregon: Oregon Department of Geology and Mineral Industries Map QM-4, scale 1:62,500.

Armstrong, J.E., 1981, Post-Vashon Wisconsin glaciations, Fraser Lowland, British Columbia: Geological Survey of Canada Bulletin 322, 34 p.

Atwater, B.F., 1986, Pleistocene glacial-lake deposits of the Sanpoil River valley, northeastern Washington: U.S. Geological Survey Bulletin 1661, 39 p.

Bacon, C.R., 1983, Eruptive history of Mount Mazama and Crater Lake Caldera, Cascade Range, U.S.A.: Journal of Volcanology and Geothermal Research, v. 18, p. 57-115.

Baker, V.R., 1973, Paleohydrology and sedimentology of Lake Missoula flooding in eastern Washington: Geological Society of America Special Paper 144, 79 p.

Baldwin, E.M., Brown, R.D., Jr., Gair, J.E., and Pease, M.H., Jr., 1955, Geology of the Sheridan and McMinnville quadrangles, Oregon: U.S. Geological Survey Oil and Gas Investigations Map OM-155, scale $1: 62,500$.

Balster, C.A., and Parsons, R.B., 1968, Geomorphology and soils, Willamette Valley, Oregon: Corvallis, Oregon State University Agricultural Experiment Station Special Report 265, 31 p.

1969, Late Pleistocene stratigraphy, southern

Willamette Valley, Oregon: Northwest Science, v. 43, p. 116-129.

Beaulieu, J.D., Hughes, P.W., and Mathiot, R.K., 1974, Environmental geology of western Linn County, Oregon: Oregon Department of Geology and Mineral Industries Bulletin 84, 117 p.

Beeson, M.H., Tolan, T.L, Madin, I.P., 1989, Geologic map of the Lake Oswego quadrangle-Clackamas, Multnomah, and Washington Counties, Oregon: Oregon Department of Geology and Mineral Industries Geological Map Series GMS-59, scale 1:24,000. 1991, Geologic map of the Portland quadrangle, Multnomah, and Washington Counties, Oregon, and Clark County, Washington: Oregon Department of
Geology and Mineral Industries Geological Map Series GMS-75, scale 1:24,000.

Bela, J.L., 1979, Geologic hazards of eastern Benton County, Oregon: Oregon Department of Geology and Mineral Industries Bulletin 98, 122 p.

-1981, Geology of the Rickreall, Salem West, Monmouth, and Sidney 7-1/2 minute quadrangles-Marion, Polk, and Linn Counties, Oregon: Oregon Department of Geology and Mineral Industries Geological Map Series GMS-18, scale 1:24,000.

Benner, P.A., and Sedell, J.R., 1997, Upper Willamette River landscape-A historic perspective, in Laenen, Antonius, and Dunnette, D.A., eds., River qualityDynamics and restoration: Boca Raton, Florida, Lewis Publishers, p. 23-47.

Benson, Larry, Burdett, James, Lund, Steve, Kashgarian, Michaele, and Mensing, Scott, 1997, Nearly synchronous climate change in the Northern Hemisphere during the last glacial termination: Nature, v. 388, p. 263-265.

Brands, M.D., 1947, Flood runoff in the Willamette Valley, Oregon: U.S. Geological Survey Water-Supply Paper 968-A, $211 \mathrm{p}$.

Bretz, J.H., 1925, The Spokane flood beyond the Channeled Scablands: Journal of Geology, v. 33, p. 97-115 and 236-259.

Brownfield, M.E., and Schlicker, H.G., 1981a, Preliminary geologic map of the Amity and Mission Bottom quadrangles, Oregon: Oregon Department of Geology and Mineral Industries Open-File Report O-81-05, scale $1: 24,000$.

1981b, Preliminary geologic map of the McMinnville and Dayton quadrangles, Oregon: Oregon Department of Geology and Mineral Industries OpenFile Report O-81-06, scale 1:24,000.

Church, Michael, 1972, Baffin Island sandurs-A study of arctic fluvial processes: Geological Survey of Canada Bulletin 216, 208 p.

Channel morphology and typology, in Carlow, P., and Petts, G.E., eds., The rivers handbook: Oxford, United Kingdom, Blackwell Scientific Publications, p. 126-143.

Clague, J.J., Mathewes, R.W., Guilbault, J.-P., Hutchinson, I., and Ricketts, B.D., 1997, Pre-Younger Dryas resurgence of the southwestern margin of the Cordilleran ice sheet, British Columbia, Canada: Boreas, v. 26, p. 261-278.

Clark, D.H., 1997, A new alpine lacustrine sedimentary record from the Sierra Nevada-Implications for late-Pleistocene paleoclimate reconstructions and cosmogenic isotope production rates [abs.]: EOS (American Geophysical Union), v. 78, p. F249. 
Clark, D.H., and Gillespie, A.R., 1997, Timing and significance of late-glacial and Holocene glaciation in the Sierra Nevada, California: Quaternary International, v. 38/39, p. 21-38.

Clark, P.U., and Bartlein, P.J., 1995, Correlation of late Pleistocene glaciation in the western United States with North Atlantic Heinrich events: Geology, v. 23, p. 483-486.

Crandell, V.R., 1965, The glacial history of western Washington and Oregon, in Wright, H.E., Jr., and Frey, D.G., eds., The Quaternary of the United States: Princeton, New Jersey, Princeton University Press, p. 341-354.

Crenna, P.A., Yeats, R.S., and Levi, Shaul, 1994, Late Cenozoic tectonics and paleogeography of the Salem Metropolitan area, central Willamette Valley, Oregon: Oregon Geology, v. 56, p. 129-136.

Dalrymple, G.B., 1989, The GLM continuous laser system for ${ }^{40} \mathrm{Ar} /{ }^{39} \mathrm{Ar}$ dating-Description and performance characteristics: U.S. Geological Survey Bulletin 1890, p. 89-96.

Dalrymple, G.B., and Duffield, W.A.,1988, High precision ${ }^{40} \mathrm{Ar} /{ }^{39} \mathrm{Ar}$ dating of Oligocene rhyolites from the Mogollon-Datil volcanic field using a continuous laser system: Geophysical Research Letters, v. 15, no. 5, p. 463-466.

Davis, J.O., 1985, Correlation of late Quaternary tephra layers in a long pluvial sequence near Summer Lake, Oregon: Quaternary Research, v. 23, p. 38-53.

Duffield, W.A., and Dalrymple, G.B., 1990, The Taylor Creek Rhyolite of New Mexico: A rapidly emplaced field of lava domes and flows: Bull. Volcanology, v. 52, p. 475-487.

Fahnestock, R.K., 1963, Morphology and hydrology of a glacial stream-White River, Mount Rainier, Washington: U.S. Geological Survey Professional Paper 442-A, 70 p.

Fleck, R.J., and Carr, M.D., 1990, The age of the Keystone Thrust: Laser-fusion ${ }^{40} \mathrm{Ar} /{ }^{39} \mathrm{Ar}$ dating of foreland basin deposits, southern Spring Mountains, Nevada: Tectonics, v. 9, no. 3, p. 467-476.

Frank, F.J., 1973, Ground water in the Eugene-Springfield area, southern Willamette Valley, Oregon: U.S. Geological Survey Water-Supply Paper 2018, 65 p.

1974, Ground water in the Corvallis-Albany area, central Willamette Valley, Oregon: U.S. Geological Survey Water-Supply Paper 2032, 48 p.

Frank, F.J., 1976, Ground water in the Harrisburg-Halsey area, southern Willamette Valley, Oregon: U.S. Geological Survey Water-Supply Paper 2040, 45 p.

Glenn, J.L., 1965, Late Quaternary sedimentation and geological history of the north Willamette Valley, Oregon: Corvallis, Oregon State University, Ph.D. dissertation, $231 \mathrm{p}$.
Gannett M.W., and Caldwell, R.C., 1998, Geologic framework of the Willamette lowland aquifer system, Oregon and Washington: U.S. Geological Survey Professional Paper 1424-A, 32 p.

Gerig, A.J., 1985, Soil survey of Clackamas County area, Oregon: U.S. Department of Agriculture, Soil Conservation Service, 293 p.

Hampton, E.R., 1972, Geology and ground water of the Molalla-Salem slope area, norther Willamette Valley, Oregon: U.S. Geological Survey Water-Supply Paper 1997, $83 \mathrm{p}$

Hallett, D.J., Hills, L.V., and Clague, J.J., 1997, New accelerator mass spectrometry radiocarbon ages for the Mazama tephra layer from Kootenay National Park, British Columbia, Canada: Canadian Journal of Earth Science, v. 34, p. 1202-1209.

Klingeman, P.C., 1987, Geomorphic influences on sediment transport in the Willamette River, in Beschta, R.L., and others, eds., Erosion and sedimentation in the Pacific Rim: International Association of Hydrological Sciences Publication 165, p. 213-223.

Knezevich, C.A., 1975, Soil survey of Benton County area, Oregon: U.S. Department of Agriculture, Soil Conservation Service, 119 p.

1982, Soil survey of Polk County, Oregon: U.S. Department of Agriculture, Soil Conservation Service, $250 \mathrm{p}$.

1987, Soil survey of Linn County area, Oregon: U.S. Department of Agriculture, Soil Conservation Service, $344 \mathrm{p}$.

Langridge. R.W., 1987, Soil survey of Linn County area, Oregon: U.S. Department of Agriculture, Soil Conservation Service, 344 p.

LoBello, P., Feraud, G., Hall, C.M., York, D., Lavina, P., and Bernat, M., 1987, ${ }^{40} \mathrm{Ar} /{ }^{39} \mathrm{Ar}$ step-heating and laser fusion dating of a Quaternary pumice from Neschers, Massif Central, France: The defeat of xenocrystic contamination: Chemical Geology, v. 66, p. 61-71.

Madin, I.P., 1990, Earthquake-hazard geology maps of the Portland metropolitan area, Oregon-Text and map explanation: Oregon Department of Geology and Mineral Industries Open-File Report O-90-2, 21 p.

1994, Geologic map of the Damascus quadrangle, Clackamas and Multnomah Counties, Oregon: Oregon Department of Geology and Mineral Industries Geological Map Series GMS-60, scale 1:24,000.

McDowell, P.F., 1991, Quaternary stratigraphy and geomorphic surfaces of the Willamette Valley, Oregon, in Morrison, R.B., ed., Quaternary nonglacial geologyConterminous United States: Geological Society of America, Decade of North American Geology, v. K2, p. 156-164. 
McDowell, P.F., and Roberts, M.C., 1987, Field guidebook to the Quaternary stratigraphy, geomorphology and soils of the Willamette Valley, Oregon: Association of American Geographers, Annual meeting, Portland, Oregon, 1987, Field trip 3, 75 p.

Merrihue, C. and Turner, G., 1966, Potassium-argon dating by activation with fast neutrons: Jour. Geophysical Research, v. 71, p. 2852-2857.

Mullineaux, V.R., Wilcox, R.E., Ebaugh, F.W., Fryxell, R., and Rubin, Meyer, 1978, Age of the last major scabland flood of the Columbia Plateau in eastern Washington: Quaternary Research, v. 10, p. 67-70.

O'Connor, J.E., 1993, Hydrology, hydraulics, and geomorphology of the Bonneville Flood: Geological Society of America Special Paper 274, 83 p.

O'Connor, J.E., and Waitt, R.B., 1995, Beyond the Channeled Scabland-A field trip guide to Missoula Flood features in the Columbia, Yakima, and Walla Walla Valleys of Washington and Oregon: Oregon Geology, Part I, v. 57, no. 3, p. 51-60; Part II, v. 57, no. 4, p. 75-86; Part III, v. 57, no. 5, p. 99-115.

Orzol, L.L., Wozniak, K.C., Meissner, T.R., and Lee, D.B., 2000, Ground-water and water chemistry data for the Willamette Basin, Oregon: U.S. Geological Survey Water-Resources Investigations Report 99-4036, $65 \mathrm{p}$.

Otte, G.E., Setness, K.D., Anderson, W.A., Herbert, F.J., Jr., and Knezevich, C.A., 1974, Soil survey of Yamhill area, Oregon: U.S. Department of Agriculture, Soil Conservation Service, $130 \mathrm{p}$.

Parsons, R.B., 1979, Stratigraphy and land use of the postdiamond Hill paleosol, western Oregon: Geoderma, v. 22 , p. 67-70.

Parsons, R.B., and Herriman, R.C., 1969, Huploxerolls and Agrixerolls developed in recent alluvium, southern Willamette Valley, Oregon: Soil Science, v. 109, p. 299-309.

Patching, W.R., 1987, Soil survey of Lane County area, Oregon: U.S. Department of Agriculture, Soil Conservation Service, 369 p.

Personius, S.F., Kelsey, H.M., and Grabau, P.C., 1993, Evidence for regional stream aggradation in the central Oregon Coast Range during the Pleistocene-Holocene transition: Quaternary Research, v. 40, p. 297-308.

Pierce, K.L., 1985, Quaternary history of faulting on the Arco segment of the Lost River fault, central Idaho, in Stein, R.S., and Buckman, R.C., eds., Proceedings of workshop XXVIII on the Borah Peak, Idaho, earthquake: U.S. Geological Survey Open-File Report 85290, p. 195-206.

Piper, A.M., 1942, Ground-water resources of the Willamette Valley, Oregon: U.S. Geological Survey WaterSupply Paper 890, 194 p.

Porter, S.C., Pierce, K.L., and Hamilton, T.D., 1983, Late Pleistocene mountain glaciation in western United
States, in Porter, S.C., ed., Late Quaternary environments of the United States, Volume 1, the late Pleistocene: Minneapolis, University of Minnesota Press, p. 71-111.

Price, Donald, 1967a, Geology and water resources in the French Prairie area, northern Willamette Valley, Oregon: U.S. Geological Survey Water-Supply Paper, 1833, $98 \mathrm{p}$.

-1967b, Ground water in the Eola-Amity hills area, northern Willamette Valley, Oregon: U.S. Geological Survey Water-Supply Paper, 1847, 66 p.

Priest, G.R., 1990, Volcanic and tectonic evolution of the Cascade volcanic arc, central Oregon: Journal of Geophysical Research, v. 95, no. B12, p. 19583-19599.

Reckendorf, F.F., 1973, Techniques for identifying floodplains in Oregon: Corvallis, Oregon State University, Ph.D. dissertation, $344 \mathrm{p}$.

Reckendorf, Fred, 1993, Geomorphology, stratigraphy, and soil interpretations, Willamette Valley, Oregon, in Kimble, J.M., ed., Proceedings of the eighth international soil management workshop-Utilization of soil-survey information for sustainable land use, Oregon, California, and Nevada (July 11-24, 1992): Soil Conservation Service, p. 178-200.

Rieck, H.J., Sarna-Wojcicki, A.M., Meyer, C.E., and Adam, D.P., 1992, Magnetostratigraphy and tephrochronology of upper Pliocene to Holocene lake sediments at Tulelake, Siskiyou, and Modoc Counties, northern California: Geological Society of America Bulletin, v. 104, p. 409-428.

Roberts, M.C., 1984, The late Cenozoic history of an alluvial fill-The southern Willamette Valley, Oregon, in Mahaney, W.C., ed., Correlation of Quaternary chronologies: Norwich, Great Britain, Geo Books, p. 491504.

Samson, S.D., and Alexander, E.C., 1987, Calibration of the interlaboratory ${ }^{40} \mathrm{Ar} /{ }^{39} \mathrm{Ar}$ dating standard, MMhb-1: Chemical Geology (Isotope Geoscience Section), v. 66 , p. 27-34.

Sarna-Wojcicki, A.M., Bowman, H.R., Meyer, C.E., Russell, P.C., Woodward, M.J., McCoy, Gail, Rowe, J.J., Jr., Baedecker, P.A., Asaro, Frank, Michael, Helen, 1984, Chemical analyses, correlations, and ages of upper Pliocene and Pleistocene ash layers of east-central and southern California: U.S. Geological Survey Professional Paper 1293, 40 p.

Sarna-Wojcicki, A.M., and Davis, J.O., 1991, Quaternary tephrochronology, in Morrison, R.B., ed., Quaternary nonglacial geology - Conterminous United States: Geological Society of America, DNAG Series, v. K2, p. 93-116. 
Sarna-Wojcicki, A.M., Meyer, C.E., Bowman, H.R., Hall, N.T., Russell, P.C., Woodward, M.L., and Slate, J.L., 1985, Correlation of the Rockland ash bed-A 400,000-year-old stratigraphic marker in northern California and western Nevada, and implications for middle Pleistocene paleogeography of central California: Quaternary Research, v. 23, p. 236-257.

Sedell, J.R., and Froggatt, J.L., 1984, Importance of streamside forests to large rivers-The isolation of the Willamette River, Oregon, U.S.A., from its floodplain by snagging and streamside forest removal: Internationale Vereinigung für theoretische and angewandte Limnologie Verhandlungen, v. 22, p. $1828-1834$.

Sherrod, V.R., 1986, Geology, geochronology, and volcanic history of a portion of the Cascade Range between latitudes $43^{\circ}-44^{\circ}$ N, central Oregon, U.S.A.: Santa Barbara, University of California, Ph.D. dissertation, $320 \mathrm{p}$.

1991, Geologic map of a part of the Cascade Range between latitudes $43^{\circ}-44^{\circ}$, central Oregon: U.S. Geological Survey Miscellaneous Investigations Series Map I-1891 with accompanying pamphlet, scale 1:125,000.

Sherrod, D. R., and Pickthorn, L. G., 1989, Some notes on the Neogene structural evolution of the Cascade Range in Oregon, in, Muffler, L.J.P., Weaver, C.S., and Blackwell, D.D., Geological, geophysical, and tectonic setting of the Cascade Range: U.S. Geological Survey Open-File Report 89-178, p. 351-368.

Smith, G.A., 1993, Missoula Flood dynamics and magnitudes inferred from sedimentology of slack-water deposits on the Columbia Plateau, Washington: Geological Society of America Bulletin, v. 105, p. 77100.

Steiger, R.H., and Jager, E., 1977, Subcommission on geochronology-Convention on the use of decay constants in geo- and cosmochronology: Earth and Planetary Science Letters, v. 36, p. 359-362.
Swanson, T.W., and Porter, S.C., 1997, New cosmogenic isotope ages for the last glaciation in the eastern North Cascade Range [abs.]: Geological Society of America Abstracts with Program, v. 29, no. 6, p. A-109.

Taylor, J.R., 1982, An introduction to error analysis-The study of uncertainties in physical measurements: Mill Valley, California, University Science Books, 270 p.

Trimble, D.E., 1963, Geology of Portland, Oregon, and adjacent areas: U.S. Geological Survey Bulletin 1119, $119 \mathrm{p}$.

Waitt, R.B., 1980, About 40 last-glacial Lake Missoula jökulhlaups through southern Washington: Journal of Geology, v. 88, p. 653-679.

1985, Case for periodic, colossal jökulhlaups from Pleistocene glacial Lake Missoula: Geological Society of America Bulletin, v. 96, p. 1271-1286.

Walker, G.W., and Duncan, R.A., 1989, Geologic map of the Salem $1^{\circ}$ by $2^{\circ}$ quadrangle, western Oregon: U.S. Geological Survey Miscellaneous Investigations Series Map I-1893.

Walker, G.W., and MacLeod, N.S., 1991, Geologic map of Oregon: U.S. Geological Survey, scale 1:500,000.

Williams, L.H., 1972, Soil survey of the Marion County area, Oregon: U.S. Department of Agriculture, Soil Conservation Service, $132 \mathrm{p}$.

Woodward, D.G., Gannett, M.W., and Vaccaro, J.J., 1998, Hydrogeologic framework of the Willamette lowland aquifer system, Oregon and Washington: U.S. Geological Survey Professional Paper 1424-B, 82 p.

Yeats, R.S., Graven, E.P., Werner, K.S., Goldfinger, Chris, and Popowski, T.S., 1996, Tectonics of the Willamette Valley, Oregon, in Rogers, A.M. and others, eds., Assessing earthquake hazards and reducing risk in the Pacific Northwest-Volume 1: U.S. Geological Survey Professional Paper 1560, p. 183-222.

York, D., Hall, C.M., Yanase, Y., Hanes, J.A., and Kenyon, M.J., 1981, ${ }^{40} \mathrm{Ar} /{ }^{39} \mathrm{Ar}$ dating of terrestrial minerals with a continuous laser: Geophysical Research Letters, v. 8, p.1136-1138. 
APPENDIXES 



\section{APPENDIX $1-{ }^{40} \mathrm{Ar} /{ }^{39} \mathrm{Ar}$ analyses of volcanic materials}

We used laser fusion (York and others, 1981) and incremental-heating (Merrihue and Turner, 1966) methods of ${ }^{40} \mathrm{Ar} /{ }^{39} \mathrm{Ar}$ analysis to determine the ages of volcanic clasts from alluvial deposits in the Willamette Valley. Laser-fusion techniques allow dating of single or small numbers of mineral grains, and, for this study, followed the procedures of LoBello and others (1987), Dalrymple and Duffield (1988), and Fleck and Carr (1990). Approximately six analyses were performed for each sample. The incremental-heating analyses utilized a low-blank, tantalum and molybdenum, resistance-heated furnace, and 100 to $200 \mathrm{mg}$ (milligrams) samples. Total gas was released in 8 to 15 heating increments. The incremental-heating analyses were performed on the same mass spectrometer and using the same argon-extraction system described by Dalrymple (1989).

Samples for ${ }^{40} \mathrm{Ar} /{ }^{39} \mathrm{Ar}$ dating were irradiated for 2 hours in the U.S. Geological Survey TRIGA Reactor Facility in Denver, Colorado. An intralaboratory standard sanidine, 85G003, (Taylor Creek Rhyolite, $27.92 \mathrm{Ma}$ ) was used for calculation of the neutron flux in all irradiations. The age of this monitor mineral is as reported by Duffield and Dalrymple (1990), standardized to an average age of 513.9 Ma measured in the U.S. Geological Survey Menlo Park laboratory for interlaboratory standard hornblende, MMhb1 (Samson and Alexander, 1987), and our intralaboratory standard biotite, SB-3. Decay and abundance constants for all ages reported are those recommended by Steiger and Jager (1977).

Summary results are presented in table A1-1; results from the incremental-heating analyses are shown in table A1-2. The results of the laser-fusion analyses from the two samples of obsidian from the weathered terrace gravels (unit QTg) yielded discordant results, indicating that individual analyses differed by more than $2 \sigma$ and that there was probably loss of radiogenic argon following initial cooling of the obsidian. This may have been due to weathering. The results from the two samples of obsidian from the Pleistocene sand and gravel $\left(\mathrm{unit}_{\mathrm{Q}} \mathrm{Qg}_{2}\right)$ were concordant and yielded mutually consistent results. Step-heating analyses from one of the Inman Creek clasts failed to define a distinguishable plateau or isochron.

Table A1-1. Argon(40)-argon(39) ages

[Analyses by Robert J. Fleck. Latitude and longitude given in decimal degrees. ID, identification; Ma, millions of years before present; $\mathrm{m}$, meters]

\begin{tabular}{|c|c|c|c|c|c|c|c|}
\hline \multirow[b]{2}{*}{ Sample ID } & \multicolumn{2}{|c|}{ Location } & \multirow{2}{*}{$\begin{array}{l}\text { Laser-fusion } \\
\text { age }^{1} \\
(\mathrm{Ma})\end{array}$} & \multicolumn{2}{|c|}{ Incremental Heating Method ${ }^{2}$} & \multirow[b]{2}{*}{$\begin{array}{l}\text { Best estimate } \\
\text { (Ma) }\end{array}$} & \multirow[b]{2}{*}{ Comments } \\
\hline & Latitude & Longitude & & Plateau age (Ma) & $\begin{array}{l}\text { Isochron age } \\
(\mathrm{Ma})\end{array}$ & & \\
\hline DSG-2 & \multicolumn{2}{|c|}{ Delta Sand and Gravel } & $0.414 \pm 0.015$ & $0.417 \pm 0.005$ & $0.419 \pm 0.008$ & $0.418 \pm 0.010$ & \multirow{3}{*}{$\begin{array}{l}\text { Obsidian clasts } \\
\text { within lahar depos- } \\
\text { its exposed approx- } \\
\text { imately } 25 \text { m below } \\
\text { surface }\end{array}$} \\
\hline & \multirow[t]{2}{*}{$44.1063 \mathrm{~N}$} & \multirow[t]{2}{*}{$123.1098 \mathrm{~W}$} & & & & & \\
\hline UBPT-1 & & & $0.414 \pm 0.008$ & $0.426 \pm 0.003$ & $0.427 \pm 0.004$ & $0.426 \pm 0.004$ & \\
\hline JEO & \multirow{3}{*}{$\begin{array}{l}\text { Inman Creek } \\
44.1095 \mathrm{~N}\end{array}$} & \multirow{3}{*}{$123.3257 \mathrm{~W}$} & $0.923 \pm 0.015$ & $0.807 \pm 0.020$ & $0.699 \pm 0.187$ & $0.750 \pm 0.060$ & \multirow{3}{*}{$\begin{array}{l}\text { Obsidian clasts } \\
\text { within weathered } \\
\text { terrace gravels (unit } \\
\text { QTg) }\end{array}$} \\
\hline $12 / 29198-1 \mathrm{~L}$ & & & (aiscora & & & & \\
\hline $\begin{array}{l}\text { JEO } \\
12 / 29 / 98-1 \mathrm{M}\end{array}$ & & & $\begin{array}{l}0.751 \pm 0.250 \\
\left.\text { discordant }^{4}\right)\end{array}$ & $\begin{array}{l}\text { No distinguishable } \\
\text { plateau }\end{array}$ & $\begin{array}{l}\text { No isochron } \\
\text { defined }\end{array}$ & $0.750 \pm 0.250$ & \\
\hline
\end{tabular}

${ }^{1}$ Age represents weighted mean of measurements (Taylor, 1982). The error stated is $\pm 1 \sigma$ as judged by the analytical data alone.

${ }^{2}$ The error stated is $\pm 1 \sigma$ as judged by the analytical data alone.

${ }^{3}$ The "final age" and approximate error was determined from final analytical results and subjective consideration of the quality of the experiments.

${ }^{4}$ Individual results from multiple laser-fusion analyses of the sample differed by more than $2 \sigma$. 
Table A1-2. ${ }^{40} \mathrm{Ar} /{ }^{39} \mathrm{Ar}$ incremental-heating analysis results

[Analyses by Robert J. Fleck. ${ }^{\circ} \mathrm{C}$, degrees Celsius; ka, thousands of years before present]

\begin{tabular}{|c|c|c|c|c|c|c|c|}
\hline $\begin{array}{l}\text { Step } \\
\left({ }^{\circ} \mathrm{C}\right)\end{array}$ & $\begin{array}{l}\text { Percent } \\
{ }^{39} \mathrm{Ar}\end{array}$ & $\begin{array}{l}\text { Percent } \\
{ }^{40} \mathrm{Ar}\end{array}$ & $\begin{array}{l}\text { Percent } \\
{ }^{36} \mathrm{Ar}_{\mathrm{Ca}}\end{array}$ & ${ }^{40} \mathrm{Ar} /{ }^{39} \mathrm{Ar}$ & ${ }^{37} \mathrm{Ar} /{ }^{39} \mathrm{Ar}$ & ${ }^{36} \mathrm{Ar} /{ }^{39} \mathrm{Ar}$ & Age (ka) \\
\hline \multicolumn{8}{|c|}{ Sample DSG-2, Delta Sand and Gravel } \\
\hline 450 & 0.53 & 3.62 & 0.32 & 10.69312 & 0.3993 & 0.03499 & $221 \pm 130$ \\
\hline 500 & 2.12 & 24.35 & .12 & 3.1993 & .1316 & .00823 & $445 \pm 33$ \\
\hline 550 & 4.62 & 30.09 & .99 & 2.0040 & .1685 & .00479 & $344 \pm 10$ \\
\hline 600 & 6.12 & 49.24 & 1.24 & 1.3916 & .1064 & .00242 & $391 \pm 8$ \\
\hline 650 & 6.14 & 54.80 & 1.53 & 1.2660 & .1073 & .00197 & $397 \pm 8$ \\
\hline 700 & 11.91 & 64.18 & 2.25 & 1.1005 & .1093 & .00136 & $404 \pm 5$ \\
\hline 750 & 24.01 & 71.82 & 2.87 & 1.0229 & .1026 & .00100 & $420 \pm 3$ \\
\hline 775 & 14.50 & 67.16 & 2.38 & 1.1011 & .1062 & .00125 & $423 \pm 4$ \\
\hline 800 & 17.09 & 62.54 & 1.99 & 1.1633 & .1068 & .00150 & $416 \pm 4$ \\
\hline 825 & 4.97 & 60.87 & 1.57 & 1.3117 & .0985 & .00176 & $456 \pm 9$ \\
\hline 850 & 1.74 & 12.33 & .24 & 5.6664 & .1465 & .00169 & $399 \pm 27$ \\
\hline 875 & .84 & 47.86 & .73 & 2.4912 & .1145 & .00443 & $681 \pm 51$ \\
\hline 950 & .95 & 12.31 & .85 & 3.6721 & .3328 & .01099 & $258 \pm 45$ \\
\hline 1,050 & 1.09 & 33.47 & 1.77 & 2.4927 & .3610 & .00571 & $477 \pm 39$ \\
\hline 1,400 & 3.38 & 32.88 & .46 & 2.3626 & .0892 & .00539 & $444 \pm 13$ \\
\hline \multicolumn{8}{|c|}{ Sample UBPT-1, Delta Sand and Gravel } \\
\hline 450 & .28 & negative & .26 & 5.5245 & .2064 & .02219 & negative \\
\hline 500 & 1.93 & 14.96 & .64 & 2.4952 & .1650 & .00723 & $219 \pm 34$ \\
\hline 550 & 3.49 & 30.74 & .90 & 1.8860 & .1431 & .00446 & $339 \pm 12$ \\
\hline 600 & 7.39 & 58.42 & 1.84 & 1.2023 & .1126 & .00172 & $411 \pm 6$ \\
\hline 650 & 7.32 & 66.08 & 2.46 & 1.0434 & .1075 & .00123 & $404 \pm 6$ \\
\hline 700 & 27.60 & 80.41 & 4.15 & .9108 & .0931 & .00063 & $429 \pm 3$ \\
\hline 725 & 14.70 & 82.67 & 4.92 & .8814 & .0953 & .00054 & $427 \pm 4$ \\
\hline 750 & 9.95 & 77.55 & 3.68 & .9328 & .0962 & .00074 & $423 \pm 5$ \\
\hline 775 & 11.08 & 74.39 & 2.79 & 1.0016 & .0888 & .00089 & $436 \pm 5$ \\
\hline 800 & 5.82 & 67.87 & 1.77 & 1.0891 & .0761 & .00121 & $433 \pm 7$ \\
\hline 825 & 4.52 & 22.12 & .51 & 3.2812 & .1563 & .00869 & $425 \pm 11$ \\
\hline 850 & 1.56 & 39.56 & .63 & 1.7683 & .0822 & .00364 & $409 \pm 26$ \\
\hline 875 & .84 & 27.64 & .37 & 2.1456 & .0689 & .00527 & $347 \pm 48$ \\
\hline 925 & .86 & 19.27 & .61 & 2.9248 & .1757 & .00804 & $330 \pm 47$ \\
\hline 1,025 & 1.63 & 26.30 & .44 & 2.5938 & .1012 & .00650 & $399 \pm 25$ \\
\hline 1,200 & 1.05 & 20.51 & .50 & 4.0151 & .1920 & .01085 & $482 \pm 39$ \\
\hline \multicolumn{8}{|c|}{ Sample JEO12298-1I, Inman Creek } \\
\hline 475 & .26 & .59 & .02 & 92.8457 & .1860 & .31241 & $407 \pm 1,086$ \\
\hline 525 & .99 & 9.61 & .07 & 18.1652 & .1429 & .05560 & $1,304 \pm 259$ \\
\hline 560 & 1.67 & 8.96 & .09 & 14.8985 & .1426 & .04594 & $997 \pm 155$ \\
\hline 610 & 3.09 & 6.22 & .07 & 18.6403 & .1491 & .05920 & $866 \pm 95$ \\
\hline 660 & 4.13 & 8.63 & .10 & 13.7689 & .1510 & .04262 & $887 \pm 71$ \\
\hline 710 & 5.03 & 8.15 & .10 & 13.3097 & .1473 & .04141 & $810 \pm 61$ \\
\hline 760 & 7.52 & 7.88 & .11 & 12.8657 & .1502 & .04015 & $756 \pm 47$ \\
\hline 800 & 11.08 & 8.65 & .10 & 13.0348 & .1487 & .04034 & $842 \pm 41$ \\
\hline 850 & 10.74 & 7.96 & .10 & 13.8590 & .1488 & .04321 & $823 \pm 43$ \\
\hline 900 & 10.81 & 7.25 & .10 & 13.8653 & .1482 & .04356 & $751 \pm 43$ \\
\hline
\end{tabular}


Table A1-2. ${ }^{40} \mathrm{Ar} /{ }^{39} \mathrm{Ar}$ incremental-heating analysis results-Continued

[Analyses by Robert J. Fleck. ${ }^{\circ} \mathrm{C}$, degrees Celsius; ka, thousands of years before present]

\begin{tabular}{|c|c|c|c|c|c|c|c|}
\hline $\begin{array}{l}\text { Step } \\
\left({ }^{\circ} \mathrm{C}\right)\end{array}$ & $\begin{array}{l}\text { Percent } \\
{ }^{39} \mathrm{Ar}\end{array}$ & $\begin{array}{l}\text { Percent } \\
{ }^{40} \mathrm{Ar}\end{array}$ & $\begin{array}{l}\text { Percent } \\
{ }^{36} \mathrm{Ar}_{\mathrm{Ca}}\end{array}$ & ${ }^{40} \mathrm{Ar} /{ }^{39} \mathrm{Ar}$ & ${ }^{37} \mathrm{Ar} /{ }^{39} \mathrm{Ar}$ & ${ }^{36} \mathrm{Ar} /{ }^{39} \mathrm{Ar}$ & Age (ka) \\
\hline \multicolumn{8}{|c|}{ Sample JEO12298-1I, Inman Creek—Continued } \\
\hline 950 & 11.36 & 8.48 & 0.10 & 13.8965 & 0.1480 & 0.04308 & $880 \pm 42$ \\
\hline 1,000 & 10.67 & 8.63 & .10 & 13.9994 & .1477 & .04333 & $902 \pm 43$ \\
\hline 1050 & 9.46 & 9.92 & .10 & 13.9302 & .1463 & .04251 & $1,032 \pm 45$ \\
\hline 1100 & 7.00 & 11.07 & .10 & 13.9935 & .1475 & .04215 & $1,157 \pm 51$ \\
\hline 1175 & 4.75 & 12.69 & .09 & 15.6062 & .1432 & .04615 & $1,478 \pm 67$ \\
\hline 1260 & 1.44 & 12.19 & .08 & 17.8695 & .1463 & .05314 & $1,625 \pm 181$ \\
\hline \multicolumn{8}{|c|}{ Sample JEO12298-1M, Inman Creek } \\
\hline 475 & .07 & -2.30 & .03 & 82.0042 & .3253 & .28405 & negative \\
\hline 535 & .61 & .52 & .03 & 43.1678 & .1563 & .14537 & $163 \pm 283$ \\
\hline 600 & 1.68 & -1.07 & .03 & 40.9656 & .1571 & .14016 & negative \\
\hline 650 & 3.09 & -.12 & .03 & 40.2040 & .1597 & .13626 & negative \\
\hline 700 & 3.56 & .26 & .03 & 39.9197 & .1570 & .13478 & $77 \pm 119$ \\
\hline 740 & 4.95 & 2.23 & .03 & 39.7767 & .1462 & .13165 & $650 \pm 118$ \\
\hline 775 & 5.85 & 1.29 & .03 & 39.5586 & .1504 & .13218 & $375 \pm 118$ \\
\hline 790 & 4.52 & 1.83 & .03 & 39.6248 & .1334 & .13168 & $533 \pm 118$ \\
\hline 800 & 4.57 & 2.98 & .03 & 39.6805 & .1415 & .13032 & $869 \pm 117$ \\
\hline 810 & 4.29 & 2.03 & .03 & 39.9259 & .1483 & .13242 & $594 \pm 118$ \\
\hline 820 & 4.52 & 1.55 & .03 & 39.5350 & .1496 & .13176 & $450 \pm 117$ \\
\hline 830 & 4.51 & 1.42 & .03 & 39.5901 & .1475 & .13211 & $414 \pm 118$ \\
\hline 840 & 4.52 & 1.60 & .03 & 39.5976 & .1519 & .13190 & $464 \pm 118$ \\
\hline 850 & 4.52 & 2.16 & .03 & 39.5002 & .1510 & .13083 & $627 \pm 117$ \\
\hline 860 & 4.01 & 1.61 & .03 & 39.4510 & .1512 & .13140 & $467 \pm 117$ \\
\hline 870 & 3.95 & 2.45 & .03 & 39.5525 & .1477 & .13061 & $712 \pm 117$ \\
\hline 880 & 3.71 & 2.74 & .03 & 39.5939 & .1464 & .13036 & $797 \pm 117$ \\
\hline 890 & 3.53 & 2.34 & .03 & 39.7615 & .1487 & .13145 & $682 \pm 118$ \\
\hline 900 & 3.57 & 3.11 & .03 & 39.7395 & .1485 & .13034 & $908 \pm 117$ \\
\hline 910 & 3.53 & 3.14 & .03 & 39.9974 & .1495 & .13114 & $923 \pm 118$ \\
\hline 920 & 3.38 & 3.24 & .03 & 39.9654 & .1483 & .13090 & $952 \pm 118$ \\
\hline 930 & 4.09 & 3.61 & .03 & 39.8843 & .1448 & .13014 & $1,058 \pm 117$ \\
\hline 940 & 3.59 & 3.98 & .03 & 40.0540 & .1456 & .13019 & $1,172 \pm 118$ \\
\hline 950 & 2.70 & 4.52 & .03 & 40.1443 & .1448 & .12975 & $1,333 \pm 119$ \\
\hline 965 & 2.38 & 4.08 & .03 & 40.2387 & .1463 & .13066 & $1,205 \pm 142$ \\
\hline 985 & 2.23 & 4.20 & .03 & 40.5170 & .1502 & .13140 & $1,248 \pm 147$ \\
\hline 1,020 & 2.27 & 4.16 & .03 & 41.0200 & .1447 & .13308 & $1,253 \pm 147$ \\
\hline 1,080 & 2.63 & 5.13 & .03 & 42.5001 & .1445 & .13649 & $1,599 \pm 140$ \\
\hline 1,200 & 3.29 & 6.84 & .03 & 42.5161 & .1431 & .13407 & $2,136 \pm 129$ \\
\hline
\end{tabular}




\section{APPENDIX 2-Analytical Methods and Results for Tephra Analysis}

Volcanic glass shards separated from macroscopic tephra layers or zones of disseminated pumice sampled from outcrops (table A2-1) were analyzed using methods described by Sarna-Wojcicki and others (1984) and Sarna-Wojcicki and others (1985). The polished glass shards were analyzed for $\mathrm{Si}, \mathrm{Al}, \mathrm{Fe}, \mathrm{Mg}$, $\mathrm{Mn}, \mathrm{Ca}$, Ti, Na, and K. Approximately 15 to 20 shards were analyzed from each sample. Some samples contained two or more compositional modes, and each mode was analyzed separately (table A2-2).

Results of analyses were compared with our database of approximately 4,200 previously analyzed samples of volcanic glasses from upper Neogene and Quaternary tephra layers collected within the conterminous Western United States and from bottom sediments of the adjacent Pacific Ocean. The best matches were identified using numerical and statistical programs (SIMANAL; Sarna-Wojcicki and others, 1984), which were then further examined for petrographic similarity and for stratigraphic position and sequence (SarnaWojcicki and Davis, 1991). Final interpretation of potential correlation of sampled tephras with known tephras (table A2-1) was made on the basis of (1) chemical composition of volcanic glass (excluding or minimally weighting those elements present in concentrations close to detection limits), (2) petrographic characteristics, and (3) stratigraphic position.

Table A2-1. Willamette Valley tephra and pumice correlations

[Samples from sections exposed along Willamette River (shown in figure 10) are listed in downstream and downsection order. Correlations of unknown tephra layers in the Willamette Valley to known tephras were determined from statistical comparison of chemical compositions, petrographic examination, and qualitative assessment of stratigraphic position. Some fluvial pumice accumulations consisted of multiple compositional modes, denoted as "major" and "minor" depending on relative abundance, which were analyzed separately. ${ }^{14} \mathrm{C} \mathrm{yr} \mathrm{BP}$, radiocarbon years before present; $\mathrm{cm}$, centimeter; ka, thousand of years before present; $\mathrm{m}$, meter; Ma, millions of years before present; mm, millimeter]

\begin{tabular}{|c|c|c|c|c|c|c|}
\hline $\begin{array}{l}\text { Sample } \\
\text { number }\end{array}$ & \multicolumn{2}{|c|}{ Location } & Stratigraphic context & $\begin{array}{c}\text { Correlative } \\
\text { tephra layer } \\
\text { (source area) }\end{array}$ & $\begin{array}{c}\text { Age of tephra } \\
\left({ }^{14} \mathrm{C} \text { yr BP }\right. \\
\text { except as } \\
\text { noted })\end{array}$ & $\begin{array}{l}\text { Comments regarding } \\
\text { stratigraphic rela- } \\
\text { tions and sources of } \\
\text { age information }\end{array}$ \\
\hline \begin{tabular}{|l|} 
JEO 9/11/96-1(6) \\
\end{tabular} & & & $\begin{array}{l}\text { Silty airfall tephra col- } \\
\text { lected } 1.8 \mathrm{~m} \text { below } \\
\text { modern surface from a } \\
<0.5 \mathrm{~cm} \text { discontinuous } \\
\text { layer that has apparently } \\
\text { been bioturbated and } \\
\text { slightly reworked by sur- } \\
\text { face processes. Sample was } \\
\text { collected from a slightly } \\
\text { thicker accumulation at the } \\
\text { bottom of a paleoswale. } \\
\text { About } 0.75 \text { m below hori- } \\
\text { zon containing dispersed } \\
\text { charcoal dated } 5,860 \\
\pm 120{ }^{14} \mathrm{C} \text { yr BP. Near } \\
\text { base of Holocene over- } \\
\text { bank deposits thinly cap- } \\
\text { ping unit Qff } 2\end{array}$ & $\begin{array}{l}\text { Mazama } \\
\text { (Crater Lake) }\end{array}$ & $6,730 \pm 40$ & $\begin{array}{l}\text { Hallett and others, } \\
1997\end{array}$ \\
\hline
\end{tabular}


Table A2-1. Willamette Valley tephra and pumice correlations (Continued)

[Samples from sections exposed along Willamette River (shown in figure 10) are listed in downstream and downsection order. Correlations of unknown tephra layers in the Willamette Valley to known tephras were determined from statistical comparison of chemical compositions, petrographic examination, and qualitative assessment of stratigraphic position. Some fluvial pumice accumulations consisted of multiple compositional modes, denoted as "major" and "minor" depending on relative abundance, which were analyzed separately. ${ }^{14} \mathrm{C}$ yr BP, radiocarbon years before present; $\mathrm{cm}$, centimeter; ka, thousand of years before present; $\mathrm{m}$, meter; Ma, millions of years before present; $\mathrm{mm}$, millimeter]

\begin{tabular}{|c|c|c|c|c|c|c|}
\hline \multirow[b]{2}{*}{$\begin{array}{l}\text { Sample } \\
\text { number }\end{array}$} & \multicolumn{2}{|c|}{ Location } & \multirow[b]{2}{*}{ Stratigraphic context } & \multirow{2}{*}{$\begin{array}{l}\text { Correlative } \\
\text { Tephra layer } \\
\text { (source area) }\end{array}$} & \multirow{2}{*}{$\begin{array}{c}\text { Age of tephra } \\
\left({ }^{14} \mathrm{C} \text { yr BP }\right. \\
\text { except as } \\
\text { noted })\end{array}$} & \multirow{2}{*}{$\begin{array}{l}\text { Comments regarding } \\
\text { stratigraphic rela- } \\
\text { tions and sources of } \\
\text { age information }\end{array}$} \\
\hline & Latitude & Longitude & & & & \\
\hline \multirow[t]{2}{*}{ JEO 9/11/96-1(9) } & $\begin{array}{r}\text { Cartney } \\
44.3248 \mathrm{~N}\end{array}$ & $\begin{array}{l}\text { k section } \\
123.2150 \mathrm{~W}\end{array}$ & \multirow{2}{*}{$\begin{array}{l}\text { Pumice grains (up to } 1 \mathrm{~cm} \\
\text { diameter) within cross-bed- } \\
\text { ded fluvial sand } 4.9 \mathrm{~m} \\
\text { below the modern surface } \\
\text { in unit } \mathrm{Qg}_{2} . \text { Below paleo- } \\
\text { sol and within Linn Grav- } \\
\text { els unit as described by } \\
\text { Allison (1953) at nearby } \\
\text { Irish Bend locality }\end{array}$} & $\begin{array}{l}\text { Major Mode: } \\
\text { Wono (Crater } \\
\text { Lake) }\end{array}$ & $27,300 \pm 300$ & $\begin{array}{l}\text { Benson and others } \\
\text { (1997) dated Wono and } \\
\text { Trego Hot Springs ash } \\
\text { layers at Pyramid } \\
\text { Lake, Nevada }\end{array}$ \\
\hline & & & & $\begin{array}{l}\text { Minor Mode: } \\
\text { Summer Lake E } \\
\text { (unknown) }\end{array}$ & $\begin{array}{l}<27,300 \pm 300 \\
>23,200 \pm 300\end{array}$ & $\begin{array}{l}\text { Stratigraphically } \\
\text { between Wono and } \\
\text { Trego Hot Springs ash } \\
\text { layers at Summer Lake } \\
\text { (Davis,1985). Dates } \\
\text { from Benson and oth- } \\
\text { ers (1997) }\end{array}$ \\
\hline \multirow[t]{2}{*}{ JEO 9/11/96-1(10) } & & & \multirow{2}{*}{$\begin{array}{l}\text { Pumice grains (up to } \\
1 \mathrm{~cm} \text { diameter) within } \\
\text { cross-bedded fluvial } \\
\text { sand } 5.8 \mathrm{~m} \text { below the mod- } \\
\text { ern surface (unit } \mathrm{Qg}_{2} \text { ). } \\
\text { Below paleosol and within } \\
\text { Linn Gravels unit as } \\
\text { described by Allison } \\
(1953) \text { at nearby Irish Bend } \\
\text { locality }\end{array}$} & $\begin{array}{l}\text { Major Mode: } \\
\text { Wono (Crater } \\
\text { Lake) }\end{array}$ & $27,300 \pm 300$ & $\begin{array}{l}\text { Benson and others } \\
(1997)\end{array}$ \\
\hline & & & & $\begin{array}{l}\text { Minor Mode: } \\
\text { Summer Lake E } \\
\text { (unknown) }\end{array}$ & $\begin{array}{l}<27,300 \pm 300: \\
>23,200 \pm 300\end{array}$ & $\begin{array}{l}\text { Stratigraphically } \\
\text { between Wono and } \\
\text { Trego Hot Springs } \\
\text { ash layers at Summer } \\
\text { Lake (Davis, 1985). } \\
\text { Dates from Benson } \\
\text { and others (1997) }\end{array}$ \\
\hline WV-WF-2 & $\begin{array}{l}\text { Wheatlan } \\
45.0845 \mathrm{~N}\end{array}$ & $\begin{array}{l}\text { erry section } \\
123.0662 \mathrm{~W}\end{array}$ & $\begin{array}{l}\text { Pumice grains in fluvial } \\
\text { sand collected about } \\
15 \text { m below modern } \\
\text { surface (above paleosol } \\
\text { capping unit } \text { Qg }_{2} \text {; below } \\
\text { rhythmically bedded } \\
\text { sand and silt of unit } \\
\text { Qff }{ }_{2} \text {, within gray sands } \\
\text { that likely correspond } \\
\text { to the River Bend unit II } \\
\text { of Glenn of 1965) }\end{array}$ & $\begin{array}{l}\text { Tulelake tephra } \\
2,438 \\
\text { (unknown) }\end{array}$ & $\begin{array}{l}<27,300 \pm 300: \\
>23,200 \pm 300\end{array}$ & $\begin{array}{l}\text { Stratigraphically } \\
\text { between Wono and } \\
\text { Trego Hot Springs } \\
\text { ash layers at Tulelake } \\
\text { (Rieck and others, } \\
\text { 1992). Dates from } \\
\text { Benson and others } \\
\text { (1997) }\end{array}$ \\
\hline
\end{tabular}


Table A2-1. Willamette Valley tephra and pumice correlations-Continued

[Samples from sections exposed along Willamette River (shown in figure 10) are listed in downstream and downsection order. Correlations of unknown tephra layers in the Willamette Valley to known tephras were determined from statistical comparison of chemical compositions, petrographic examination, and qualitative assessment of stratigraphic position. Some fluvial pumice accumulations consisted of multiple compositional modes, denoted as "major" and "minor" depending on relative abundance, which were analyzed separately. ${ }^{14} \mathrm{C}$ yr BP, radiocarbon years before present; cm, centimeter; ka, thousand of years before present; $\mathrm{m}$, meter; Ma, millions of years before present; $\mathrm{mm}$, millimeter]

\begin{tabular}{|c|c|c|c|c|c|c|}
\hline \multirow[b]{2}{*}{$\begin{array}{l}\text { Sample } \\
\text { number }\end{array}$} & \multicolumn{2}{|c|}{ Location } & \multirow[b]{2}{*}{ Stratigraphic context } & \multirow{2}{*}{$\begin{array}{c}\text { Correlative } \\
\text { Tephra layer } \\
\text { (source area) }\end{array}$} & \multirow{2}{*}{$\begin{array}{l}\text { Age of tephra } \\
\left({ }^{14} \mathrm{C} \text { yr BP }\right. \\
\text { except as } \\
\text { noted })\end{array}$} & \multirow{2}{*}{$\begin{array}{l}\text { Comments regarding } \\
\text { stratigraphic rela- } \\
\text { tions and sources of } \\
\text { age information }\end{array}$} \\
\hline & Latitude & Longitude & & & & \\
\hline \multirow[t]{3}{*}{\begin{tabular}{|l|} 
JEO 9/19/96-2(2) \\
\end{tabular}} & \multicolumn{2}{|c|}{ Wheatland Ferry section } & \multirow{3}{*}{$\begin{array}{l}\text { Pumice grains in cross- } \\
\text { bedded fluvial sand } \\
\text { collected about } 18 \text { m below } \\
\text { modern surface. Below } \\
\text { paleosol and within unit } \\
\mathrm{Qg}_{2} \text {, which is locally cor- } \\
\text { relative to River Bend Unit } \\
\text { I of Glenn (1965). }\end{array}$} & Major Mode: & $<0.071 \mathrm{Ma}$ & Younger than $0.071 \mathrm{Ma}$ \\
\hline & $45.0845 \mathrm{~N}$ & $123.0662 \mathrm{~W}$ & & $\begin{array}{l}\text { Redcloud Pum- } \\
\text { ice (Crater Lake) }\end{array}$ & $\left(\mathrm{Ar}^{40} / \mathrm{Ar}^{39}\right)$ & $\begin{array}{l}\text { Pumice Castle tephra } \\
\text { (Bacon, 1983; C.R. } \\
\text { Bacon, U.S. Geologi- } \\
\text { cal Survey, oral com- } \\
\text { mun. 1997); close } \\
\text { association with Sum- } \\
\text { mer Lake E pumice at } \\
\text { Wheatland Ferry may } \\
\text { indicate Redcloud } \\
\text { pumice is also 30- } \\
23 \text { ka }\end{array}$ \\
\hline & & & & $\begin{array}{l}\text { Minor Mode: } \\
\text { Summer Lake E } \\
\text { (unknown) }\end{array}$ & $\begin{array}{l}<27,300 \pm 300: \\
>23,200 \pm 300\end{array}$ & $\begin{array}{l}\text { Stratigraphically } \\
\text { between Wono and } \\
\text { Trego Hot Springs } \\
\text { ash layers at Summer } \\
\text { Lake (Davis,1985). } \\
\text { Dates from Benson } \\
\text { and others (1997) }\end{array}$ \\
\hline \multirow[t]{2}{*}{ RBW-79-1848B } & \multicolumn{2}{|c|}{ River Bend section } & Airfall silt ash collecte & unknown & unknown & Sample collected by \\
\hline & $45.1620 \mathrm{~N}$ & 123.0000W & $\begin{array}{l}\text { about } 16.5 \text { m below mod- } \\
\text { ern surface. Described by } \\
\text { Glenn (1965) and Richard } \\
\text { Waitt (USGS, written com- } \\
\text { mun., 1998). Near base of } \\
\text { rhythmically bedded sand } \\
\text { and silt of unit Qff } 2 \text {, and } \\
\text { within transition zone of } \\
\text { River Bend units II and III } \\
\text { of Glenn (1965) }\end{array}$ & & & $\begin{array}{l}\text { Richard Waitt, USGS. } \\
\text { See description by } \\
\text { Glenn }(1965, \text { p. } 83-84)\end{array}$ \\
\hline \multirow[t]{2}{*}{ RBW-79-1848A } & \multicolumn{2}{|c|}{ River Bend section } & Pumice grains in fluvial & Tulelake tephra & $<27,300 \pm 300:$ & Sample collected by \\
\hline & $45.1620 \mathrm{~N}$ & $123.0000 \mathrm{~W}$ & $\begin{array}{l}\text { sand collected about } 19 \mathrm{~m} \\
\text { below modern surface. } \\
\text { Above paleosol capping } \\
\text { unit } \mathrm{Qg}_{2} \text { and within bedded } \\
\text { gray sands of River Bend } \\
\text { unit II (Glenn, 1965) }\end{array}$ & $\begin{array}{l}2,438 \\
\text { (unknown) }\end{array}$ & $>23,200 \pm 300$ & $\begin{array}{l}\text { Richard Waitt, USGS. } \\
\text { Stratigraphically } \\
\text { between Wono and } \\
\text { Trego Hot Springs ash } \\
\text { layers at Tulelake } \\
\text { (Rieck and others, } \\
\text { 1992). Dates from } \\
\text { Benson and others } \\
(1997)\end{array}$ \\
\hline
\end{tabular}


Table A2-1. Willamette Valley tephra and pumice correlations-Continued

[Samples from sections exposed along Willamette River (shown in figure 10) are listed in downstream and downsection order. Correlations of unknown tephra layers in the Willamette Valley to known tephras were determined from statistical comparison of chemical compositions, petrographic examination, and qualitative assessment of stratigraphic position. Some fluvial pumice accumulations consisted of multiple compositional modes, denoted as "major" and "minor" depending on relative abundance, which were analyzed separately. ${ }^{14} \mathrm{C}$ yr BP, radiocarbon years before present; cm, centimeter; ka, thousand of years before present; $\mathrm{m}$, meter; Ma, millions of years before present; $\mathrm{mm}$, millimeter]

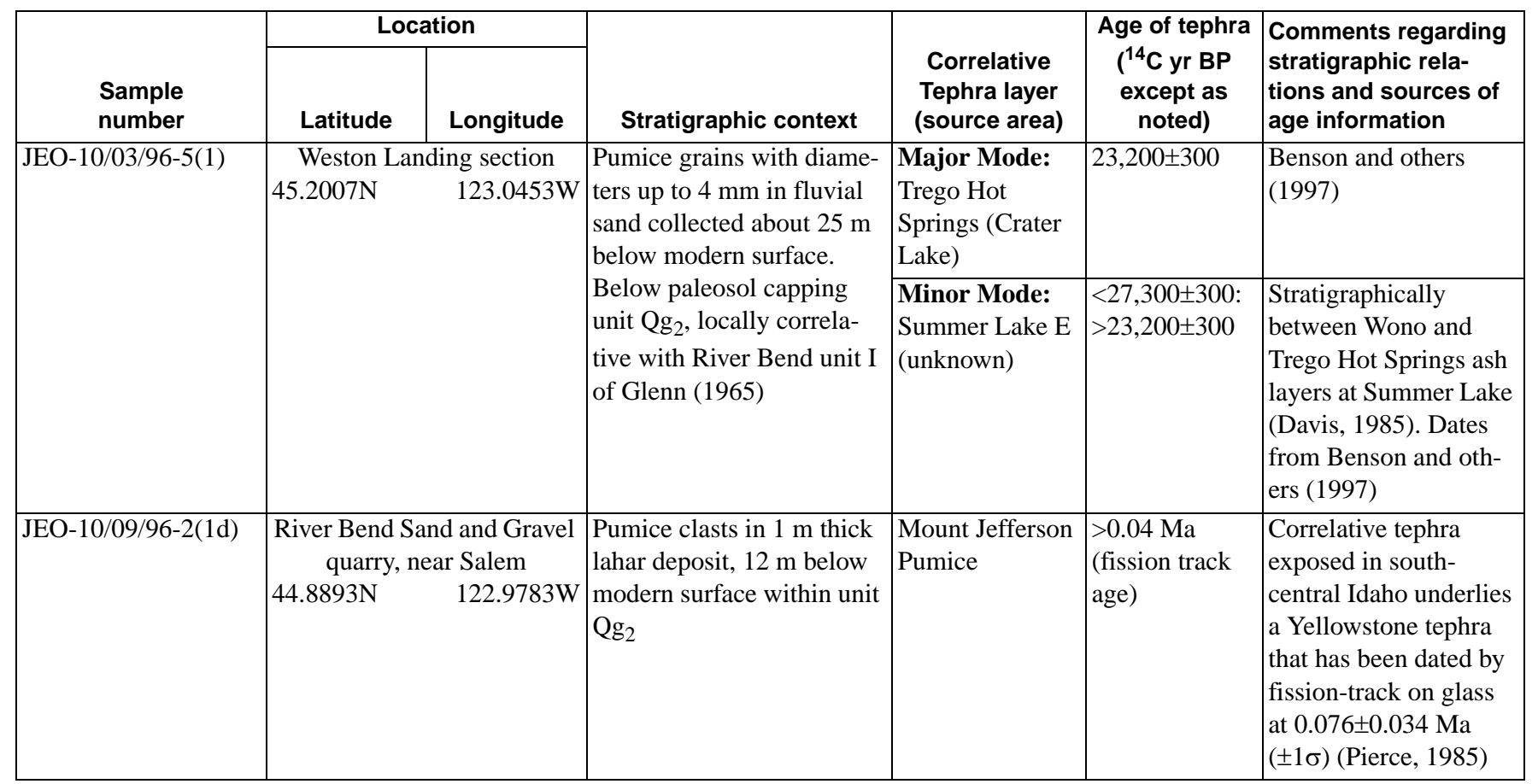


Table A2-2. Compositions of volcanic glass shards from deposits in the Willamette Valley (unshaded) and inferred correlative and dated tephra layers in the western United States (shaded)

[Values are given as oxides, in weight-percent, recalculated to 100 percent on a fluid-free basis. Replicates of a natural glass standard (RLS 132) provide indication of analytical precision. ${ }^{14} \mathrm{C}$ yr BP, radiocarbon years before present; ka, thousands of years before the present; Ma, millions of years before the present]

\begin{tabular}{|c|c|c|c|c|c|c|c|c|c|c|}
\hline Sample & $\mathrm{SiO}_{2}$ & $\mathrm{Al}_{2} \mathrm{O}_{3}$ & $\mathrm{Fe}_{2} \mathrm{O}_{3}$ & $\mathrm{MgO}$ & $\mathrm{MnO}$ & $\mathrm{CaO}$ & $\mathrm{TiO}_{2}$ & $\mathrm{Na}_{2} \mathrm{O}$ & $\mathrm{K}_{2} \mathrm{O}$ & $\Sigma \mathbf{W t} \%$ \\
\hline \multicolumn{11}{|c|}{ Mazama Correlatives $\left(6,730 \pm \mathbf{4 0}{ }^{14} \mathrm{C}\right.$ yr BP $)$} \\
\hline JEO 9/11/96-1(1) & 73.48 & 14.45 & 2.10 & 0.43 & 0.06 & 1.5 & 0.37 & 4.8 & 2.81 & 100.00 \\
\hline JEO 9/11/96-1(6) & 73.38 & 14.44 & 2.23 & .52 & .05 & 1.62 & .38 & 4.66 & 2.71 & 99.99 \\
\hline Mazama Ash average $(n=100)$ & 72.79 & 14.65 & 2.12 & .46 & .05 & 1.61 & .42 & 5.19 & 2.71 & 100.00 \\
\hline \multicolumn{11}{|c|}{ Trego Hot Springs Ash Layer Correlatives $\left(23,200 \pm 300{ }^{14} \mathrm{C}\right.$ yr BP $)$} \\
\hline JEO 10/03/96-5(1) Major Mode & 75.65 & 13.43 & 1.55 & .19 & .05 & 1.02 & .18 & 4.52 & 3.41 & 100.00 \\
\hline $\begin{array}{l}\text { LT-2 } \\
\text { [Trego Hot Springs type location] }\end{array}$ & 75.25 & 14.04 & 1.60 & .21 & .07 & 1.02 & .24 & 4.28 & 3.29 & 100.00 \\
\hline $\begin{array}{l}92 \mathrm{~B}-5.07 \\
\text { [Tephra in Pyramid Lake core } \\
\text { dated } 23,200 \pm 300{ }^{14} \mathrm{C} \text { yr BP by } \\
\text { Benson and others (1997)] }\end{array}$ & 75.52 & 13.95 & 1.64 & .21 & .05 & 1.04 & .22 & 4.05 & 3.32 & 100.00 \\
\hline Tulelake $176^{1}$ & 75.44 & 13.62 & 1.53 & .21 & .06 & 1.02 & .22 & 4.53 & 3.36 & 99.99 \\
\hline \multicolumn{11}{|c|}{ Summer Lake E Correlatives $\left(<27,300 \pm 300 ;>23,200 \pm 300{ }^{14} \mathrm{C}\right.$ yr BP $)$} \\
\hline JEO 9/11/96-1(9) Minor Mode & 77.02 & 12.92 & 1.19 & .15 & .03 & .81 & .13 & 4.16 & 3.61 & 100.02 \\
\hline JEO 9/11/96-1(10) Minor Mode & 76.84 & 13.03 & 1.22 & .15 & .05 & .84 & .16 & 4.14 & 3.57 & 100.00 \\
\hline JEO 9/19/96-2(2) Minor Mode & 76.51 & 13.15 & 1.26 & .14 & .04 & .82 & .15 & 4.31 & 3.63 & 100.01 \\
\hline JEO 10/03/96-5(1) Minor Mode ${ }^{2}$ & 76.96 & 13.08 & 1.08 & .11 & .03 & .79 & .15 & 4.28 & 3.62 & 100.00 \\
\hline $\begin{array}{l}\text { DR-82 } \\
\text { [Summer Lake E] }\end{array}$ & 76.65 & 13.14 & 1.25 & .14 & .05 & .75 & .18 & 4.21 & 3.61 & 99.98 \\
\hline \multicolumn{11}{|c|}{ Tulelake Ash Layer Correlatives $\left(<27,300 \pm 300 ;>23,200 \pm 300{ }^{\mathbf{1 4}} \mathrm{C}\right.$ yr BP $)$} \\
\hline WV-WF-2 & 76.24 & 13.43 & 1.30 & .17 & .03 & .90 & .15 & 4.29 & 3.47 & 99.98 \\
\hline RBW-79-1848A(1) & 76.16 & 13.32 & 1.36 & .16 & .02 & .89 & .16 & 4.33 & 3.60 & 100.00 \\
\hline RBW-79-1848A(2) & 76.05 & 13.37 & 1.35 & .15 & .04 & .88 & .16 & 4.59 & 3.41 & 100.00 \\
\hline Tulelake 2438 & 76.76 & 12.97 & 1.33 & .17 & .04 & .80 & .20 & 4.22 & 3.52 & 100.01 \\
\hline \multicolumn{11}{|c|}{ Wono Ash Layer Correlatives $\left(27,300 \pm 300{ }^{14} \mathrm{C}\right.$ yr BP $)$} \\
\hline JEO 9/11/96-1(9) Major Mode & 74.50 & 13.86 & 1.93 & .28 & .04 & 1.30 & .24 & 4.59 & 3.26 & 100.00 \\
\hline JEO 9/11/96-1(10) Major Mode & 74.63 & 13.89 & 1.86 & .26 & .05 & 1.32 & .22 & 4.56 & 3.2 & 99.99 \\
\hline $\begin{array}{l}\text { NIXON-2 } \\
\text { (Wono type section) }\end{array}$ & 74.54 & 13.81 & 2.10 & .30 & .06 & 1.34 & .30 & 4.46 & 3.10 & 100.01 \\
\hline $\begin{array}{l}\text { PL92B-7.85 } \\
\text { [Tephra in Pyramid Lake core } \\
\text { dated } 27,300 \pm 300{ }^{14} \mathrm{C} \text { yr BP by } \\
\text { Benson and others (1997)] }\end{array}$ & 74.34 & 13.98 & 1.96 & .26 & .05 & 1.26 & .26 & 4.64 & 3.25 & 100.00 \\
\hline \multicolumn{11}{|c|}{$\frac{1}{\text { Redcloud Pumice Correlatives (<71 ka) }}$} \\
\hline JEO 9/19/96-2(2) Major Mode & 74.87 & 13.81 & 1.77 & .24 & .04 & 1.18 & .24 & 4.51 & 3.35 & 100.01 \\
\hline CB-33 (Redcloud pumice) & 74.60 & 13.94 & 1.76 & .24 & .03 & 1.13 & .27 & 4.71 & 3.31 & 99.99 \\
\hline \multicolumn{11}{|c|}{ Mount Jefferson Pumice Correlatives (>40 ka) } \\
\hline JEO 10/09/96-2(2) & 75.10 & 13.76 & 1.72 & .32 & .04 & 1.53 & .24 & 4.74 & 2.54 & 99.99 \\
\hline $\begin{array}{l}\text { SD 1490-1 } \\
\text { [Pumice at Mount Jefferson] }\end{array}$ & 74.85 & 14.08 & 1.79 & .32 & .05 & 1.54 & .24 & 4.68 & 2.44 & 99.99 \\
\hline $\begin{array}{l}\text { ARCO A2-8 } \\
\text { [>0.040 Ma tephra in south- } \\
\text { central Idaho] }\end{array}$ & 74.98 & 13.78 & 1.79 & .31 & .05 & 1.54 & .26 & 4.77 & 2.52 & 100.00 \\
\hline \multicolumn{11}{|c|}{ Uncorrelated Samples } \\
\hline RBW-79-1848B & 76.93 & 10.62 & 2.09 & .19 & .04 & 1.03 & .21 & 5.80 & 3.38 & 99.99 \\
\hline \multicolumn{11}{|c|}{ Homogenous Glass Standard (18 electron microprobe analyses) } \\
\hline RLS 132 & 75.4 & 11.3 & 2.12 & .06 & .16 & .11 & .19 & 4.9 & 4.4 & 100.00 \\
\hline $\pm 1 \sigma$ & .1 & .2 & .04 & .01 & .01 & .01 & .01 & .1 & .1 & \\
\hline
\end{tabular}

${ }^{1}$ Tulelake 176 is within the proper stratigraphic position in the Tulelake core to be the Trego Hot Springs ash bed (Rieck and others, 1992), and its chemical composition is more similar to some of the pumices sampled from the Willamette Valley than are the "type" Trego Hot Springs samples. We infer that all of these samples are from the Trego Hot Springs eruptive event, but that the pumices have slightly variable compositions.

${ }^{2}$ JEO 10/03/96-5(1) (minor mode) is tentatively correlated with Summer Lake E, although it has significantly lower Fe and $\mathrm{Mg}$ contents. 


\section{APPENDIX $3-{ }^{14} \mathrm{C}$ age analyses}

Radiocarbon age analyses were conducted for 17 organic carbon samples (charcoal, wood, and plant fragments) collected from outcrops within the study area. Beta Analytic Inc. performed the analyses using standard procedures. Sample locations, stratigraphic context, and results are summarized in table A3-1.

Table A3-1. Radiocarbon ages obtained during this study from map area

[All analyses performed by Beta Analytic Inc. For each location, ages displayed in downsection order. Longitude and latitude in decimal degrees;

${ }^{14} \mathrm{C}$ yr BP, radiocarbon years before present; $\mathrm{cm}$, centimeter; $\mathrm{m}$, meter; $\mathrm{mm}$, millimeter; $\%$, percent]

\begin{tabular}{|c|c|c|c|c|c|c|}
\hline \multirow{2}{*}{$\begin{array}{l}\text { Laboratory } \\
\text { number }\end{array}$} & \multicolumn{2}{|c|}{ Location } & \multirow{2}{*}{\multicolumn{2}{|c|}{ Stratigraphic context }} & \multirow[b]{2}{*}{ Material analyzed } & \multirow{2}{*}{$\begin{array}{l}{ }^{14} \mathrm{C} \text { Date }{ }^{1} \\
\left({ }^{14} \mathrm{C} \text { yr BP }\right)\end{array}$} \\
\hline & \multicolumn{2}{|c|}{\begin{tabular}{|l|l} 
Latitude & Longitude
\end{tabular}} & & & & \\
\hline Beta-98559 & \multicolumn{2}{|c|}{ Wildish sand and gravel } & \multirow{2}{*}{\multicolumn{2}{|c|}{$\begin{array}{l}\text { Sandy silt about } 10 \mathrm{~cm} \text { below Qalc sur- } \\
\text { face. }\end{array}$}} & Single wood fragment & $90 \pm 50$ \\
\hline & \multirow[t]{3}{*}{$44.1115 \mathrm{~N}$} & \multirow[t]{3}{*}{$123.0850 \mathrm{~W}$} & & & & \\
\hline Beta-98558 & & & $\begin{array}{l}\text { Silt } \\
\text { sur }\end{array}$ & $\begin{array}{l}\text { y fine sand about } 1.2 \mathrm{~m} \text { below Qalc } \\
\text { ace. }\end{array}$ & Single wood fragment & $50 \pm 40$ \\
\hline Beta-98725 & & & $\begin{array}{l}\text { Flu } \\
\text { sur }\end{array}$ & $\begin{array}{l}\text { jial gravel about } 1.2 \mathrm{~m} \text { below Qalc } \\
\text { ace. }\end{array}$ & Dispersed charcoal & $520 \pm 80$ \\
\hline \multirow[t]{2}{*}{ Beta-98562 } & \multicolumn{2}{|c|}{ Wildish sand and gravel } & \multirow{4}{*}{ 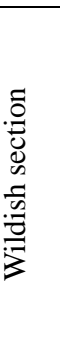 } & Sandy silt with abundant char- & Dispersed charcoal & Modern \\
\hline & \multirow[t]{3}{*}{$44.1093 \mathrm{~N}$} & \multirow[t]{3}{*}{$123.0745 \mathrm{~W}$} & & $\begin{array}{l}\text { coal, wood fragments } 1.0 \mathrm{~m} \\
\text { below Qalc surface. }\end{array}$ & and wood fragments & $(104.4 \pm 0.9 \%)^{2}$ \\
\hline Beta-98563 & & & & $\begin{array}{l}\text { Sandy silt with isolated charcoal, } \\
\text { wood, and cobbles, } 2.1 \mathrm{~m} \text { below } \\
\text { Qalc surface. }\end{array}$ & $\begin{array}{l}\text { Wood from } 10 \mathrm{~cm} \\
\text { diameter } \log \end{array}$ & $60 \pm 50$ \\
\hline Beta-98560 & & & & $\begin{array}{l}\text { Small lense of sand within sandy } \\
\text { gravel about } 4 \text { m below Qalc sur- } \\
\text { face. }\end{array}$ & Single wood fragment & $3,700 \pm 70$ \\
\hline \multirow[t]{2}{*}{ Beta-98725 } & \multicolumn{2}{|c|}{ Cartney Park section } & \multirow{2}{*}{\multicolumn{2}{|c|}{$\begin{array}{l}\text { Disseminated 1- to 2-mm charcoal } \\
\text { fragments (burned surface?) within } \\
\text { clayey silt } 1.04 \mathrm{~m} \text { below surface } \\
\text { mapped as unit Qff } \\
\text {, but locally } \\
\text { capped by } 1 \text { to } 2 \mathrm{~m} \text { of Holocene over- } \\
\text { bank deposits of the Willamette River. }\end{array}$}} & Dispersed charcoal & $5,860 \pm 120$ \\
\hline & $44.3248 \mathrm{~N}$ & $123.2150 \mathrm{~W}$ & & & & \\
\hline \multirow[t]{2}{*}{ Beta-98728 } & \multicolumn{2}{|c|}{ Bear Island } & \multirow{2}{*}{\multicolumn{2}{|c|}{$\begin{array}{l}\text { Sandy silt about } 1.8 \mathrm{~m} \text { below Qalc sur- } \\
\text { face. }\end{array}$}} & Dispersed charcoal & $230 \pm 120$ \\
\hline & $44.4730 \mathrm{~N}$ & $123.2148 \mathrm{~W}$ & & & & \\
\hline \multirow[t]{2}{*}{ Beta-98729 } & \multicolumn{2}{|c|}{$\begin{array}{c}\text { Right bank Willamette River, river } \\
\text { mile } 138.4\end{array}$} & \multirow{2}{*}{\multicolumn{2}{|c|}{$\begin{array}{l}\text { Dispersed charcoal within paleosol } \\
\text { about } 6.9 \text { m below surface mapped as } \\
\text { Qff }{ }_{2} \text {. Sample could be younger wood } \\
\text { or roots within Pleistocene paleosol, or } \\
\text { alternatively, within a small area of } \\
\text { younger deposits inset into the Pleis- } \\
\text { tocene surface. }\end{array}$}} & Dispersed charcoal & $370 \pm 100$ \\
\hline & $44.4903 \mathrm{~N}$ & $123.2123 \mathrm{~W}$ & & & & \\
\hline Beta-98565 & \multicolumn{2}{|c|}{$\begin{array}{l}\text { Left bank Willamette River, } \\
\text { river mile } 110.4\end{array}$} & \multicolumn{2}{|r|}{$\begin{array}{l}\text { Silty fine sand } 0.3 \mathrm{~m} \text { below Qalc sur- } \\
\text { face. }\end{array}$} & Dispersed charcoal & $260 \pm 80$ \\
\hline Beta-98730 & \multirow[t]{2}{*}{$44.7250 \mathrm{~N}$} & \multirow[t]{2}{*}{$123.1502 \mathrm{~W}$} & \multicolumn{2}{|c|}{$\begin{array}{l}\text { Weakly developed paleosol in silty fine } \\
\text { sand } 3.7 \text { m below Qalc surface. }\end{array}$} & Dispersed charcoal & $2,550 \pm 70$ \\
\hline Beta-98564 & & & \multicolumn{2}{|c|}{$\begin{array}{l}\text { Silty fine sand } 3.8 \mathrm{~m} \text { below Qalc sur- } \\
\text { face. }\end{array}$} & Dispersed charcoal & $2,820 \pm 100$ \\
\hline
\end{tabular}


Table A3-1. Radiocarbon ages obtained during this study from map area-Continued

\begin{tabular}{|c|c|c|c|c|c|c|}
\hline \multirow{2}{*}{$\begin{array}{c}\text { Laboratory } \\
\text { Number }\end{array}$} & \multicolumn{2}{|c|}{ Location } & \multirow{2}{*}{\multicolumn{2}{|c|}{ Stratigraphic Context }} & \multirow[b]{2}{*}{ Material Analyzed } & \multirow{2}{*}{$\begin{array}{l}{ }^{14} \mathrm{C} \text { Date }{ }^{3} \\
\left({ }^{14} \mathrm{C} \text { yr BP }\right)\end{array}$} \\
\hline & Latitude & Longitude & & & & \\
\hline \multirow[t]{2}{*}{ Beta-98724 } & \multicolumn{2}{|c|}{ Walling Sand and Gravel } & \multirow{5}{*}{ 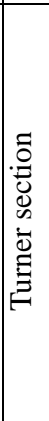 } & \multirow{2}{*}{$\begin{array}{l}\text { Sandy silt lenses within sandy, } \\
\text { cobbly, gravel, about } 1.5 \mathrm{~m} \text { below } \\
\text { slightly disturbed } \mathrm{Qg}_{1} \text { surface. }\end{array}$} & \multirow{2}{*}{$\begin{array}{l}10 \mathrm{~cm} \text { diameter wood } \\
\text { fragment with bark }\end{array}$} & \multirow[t]{2}{*}{$12,170 \pm 70$} \\
\hline & \multirow[t]{4}{*}{$44.8655 \mathrm{~N}$} & \multirow[t]{4}{*}{$122.9593 \mathrm{~W}$} & & & & \\
\hline Beta-98555 & & & & $\begin{array}{l}\text { Sand lenses within sandy, cobbly, } \\
\text { gravel, about } 1.0 \text { m below slightly } \\
\text { disturbed } \mathrm{Qg}_{1} \text { surface. }\end{array}$ & $\begin{array}{l}\text { Multiple wood frag- } \\
\text { ments }\end{array}$ & $12,290 \pm 110$ \\
\hline Beta-98557 & & & & $\begin{array}{l}\text { Sand lenses within sandy, cobbly, } \\
\text { gravel, about } 5.5 \mathrm{~m} \text { below } \mathrm{Qg}_{1} \\
\text { surface. }\end{array}$ & Single wood fragment & $>46,930$ \\
\hline Beta-98556 & & & & $\begin{array}{l}\text { Sandy, cobbly, gravel, about } \\
6.5 \mathrm{~m} \text { below } \mathrm{Qg}_{1} \text { surface. }\end{array}$ & Single wood fragment & $45,640 \pm 3,200$ \\
\hline \multirow[t]{2}{*}{ Beta-99685 } & \multicolumn{2}{|c|}{ Wheatland Ferry section } & \multirow{2}{*}{\multicolumn{2}{|c|}{$\begin{array}{l}\text { Thin organic mat capping paleosol } \\
\text { developed on unit } \mathrm{Qg}_{2} \text { and below unit } \\
\text { Qff } \\
2 \text {; about } 16 \mathrm{~m} \text { below } \mathrm{Qff}_{2} \text { surface. }\end{array}$}} & \multirow[t]{2}{*}{ Fine organic detritus } & \multirow[t]{2}{*}{$22,060 \pm 100$} \\
\hline & 45.0805 & 123.0662 & & & & \\
\hline
\end{tabular}

${ }^{1 .}$ Conventional radiocarbon ages (in ${ }^{14} \mathrm{C}$ yr BP) are based on the Libby half-life $(5,568 \mathrm{yr})$ for ${ }^{14} \mathrm{C}$. The error stated is $\pm 1 \sigma$ as judged by the analytical data alone. The age is referenced to A.D. 1950.

2. Carbon 14 content exceeds modern reference standard, indicating a post A.D. 1950 age.

3. Conventional radiocarbon ages (in ${ }^{14} \mathrm{C}$ yr BP) are based on the Libby half-life $\left(5,568 \mathrm{yr}\right.$ ) for ${ }^{14} \mathrm{C}$. The error stated is $\pm 1 \sigma$ as judged by the analytical data alone. The age is referenced to A.D. 1950. 


\section{Availability of Publications of the U.S. Geological Survey}

Order U.S. Geological Survey (USGS) publications by calling the toll-free telephone number 1-888-ASK-USGS or contacting the offices listed below. Detailed ordering instructions, along with prices of the last offerings, are given in the current-year issues of the catalog "New Publications of the U.S. Geological Survey."

\section{Books, Maps, and Other Publications}

\section{By Mail}

Books, maps, and other publications are available by mail from-

USGS Information Services

Box 25286, Federal Center

Denver, CO 80225

Publications include Professional Papers, Bulletins, WaterSupply Papers, Techniques of Water-Resources Investigations, Circulars, Fact Sheets, publications of general interest, single copies of permanent USGS catalogs, and topographic and thematic maps.

\section{Over the Counter}

Books, maps, and other publications of the U.S. Geological Survey are available over the counter at the following USGS Earth Science Information Centers (ESIC's), all of which are authorized agents of the Superintendent of Documents:

- Anchorage, Alaska-Rm.101, 4230 University Dr.

- Denver, Colorado-Bldg. 810, Federal Center

- Menlo Park, California-Rm. 3128, Bldg. 3, 345 Middlefield Rd.

- Reston, Virginia-Rm. 1 C402, USGS National Center, 12201 Sunrise Valley Dr.

- Salt Lake City, Utah-2222 West, 2300 South

- Spokane, Washington-Rm.135, U.S. Post Office Building, 904 West Riverside Ave.

- Washington, D.C.-Rm. 2650, Main Interior Bldg., 18th and C Sts., NW.

Maps only may be purchased over the counter at the following USGS office:

- Rolla, Missouri-1400 Independence Rd.

\section{Electronically}

Some USGS publications, including the catalog "New Publications of the U.S. Geological Survey" are also available electronically on the USGS's World Wide Web home page at http://www.usgs.gov

\section{Preliminary Determination of Epicenters}

Subscriptions to the periodical "Preliminary Determination of Epicenters" can be obtained only from the Superintendent of
Documents. Check or money order must be payable to the Superintendent of Documents. Order by mail from-

Superintendent of Documents

Government Printing Office

Washington, DC 20402

\section{Information Periodicals}

Many Information Periodicals products are available through the systems or formats listed below:

\section{Printed Products}

Printed copies of the Minerals Yearbook and the Mineral Commodity Summaries can be ordered from the Superintendent of Documents, Government Printing Office (address above).

Printed copies of Metal Industry Indicators and Mineral Industry Surveys can be ordered from the Center for Disease Control and Prevention, National Institute for Occupational Safety and Health, Pittsburgh Research Center, P.O. Box 18070, Pittsburgh, PA 15236-0070.

\section{Mines FaxBack: Return fax service}

1. Use the touch-tone handset attached to your fax machine's telephone jack. (ISDN [digital] telephones cannot be used with fax machines.)

2. Dial (703) 648-4999.

3. Listen to the menu options and punch in the number of your selection, using the touch-tone telephone.

4. After completing your selection, press the start button on your fax machine.

\section{CD-ROM}

A disc containing chapters of the Minerals Yearbook (199395), the Mineral Commodity Summaries (1995-97), a statistical compendium (1970-90), and other publications is updated three times a year and sold by the Superintendent of Documents, Government Printing Office (address above).

\section{World Wide Web}

Minerals information is available electronically at http://minerals.er.usgs.gov/minerals/

\section{Subscription to the catalog "New Publications of the U.S.} Geological Survey"

Those wishing to be placed on a free subscription list for the catalog "New Publications of the U.S. Geological Survey" should write to-

U.S. Geological Survey

903 National Center

Reston, VA 20192 


\section{Selected Series of U.S. Geological Survey Publications}

\section{Books and Other Publications}

Professional Papers report scientific data and interpretations of lasting scientific interest that cover all facets of USGS investigations and research.

Bulletins contain significant data and interpretations that are of lasting scientific interest but are generally more limited in scope or geographic coverage than Professional Papers.

Water-Supply Papers are comprehensive reports that present significant interpretive results of hydrologic investigations of wide interest to professional geologists, hydrologists, and engineers. The series covers investigations in all phases of hydrology, including hydrogeology, availability of water, quality of water, and use of water.

Circulars are reports of programmatic or scientific information of an ephemeral nature; many present important scientific information of wide popular interest. Circulars are distributed at no cost to the public.

Fact Sheets communicate a wide variety of timely information on USGS programs, projects, and research. They commonly address issues of public interest. Fact Sheets generally are two or four pages long and are distributed at no cost to the public.

Reports in the Digital Data Series (DDS) distribute large amounts of data through digital media, including compact disc-read-only memory (CD-ROM). They are high-quality, interpretive publications designed as self-contained packages for viewing and interpreting data and typically contain data sets, software to view the data, and explanatory text.

Water-Resources Investigations Reports are papers of an interpretive nature made available to the public outside the formal USGS publications series. Copies are produced on request (unlike formal USGS publications) and are also available for public inspection at depositories indicated in USGS catalogs.

Open-File Reports can consist of basic data, preliminary reports, and a wide range of scientific documents on USGS investigations. Open-File Reports are designed for fast release and are available for public consultation at depositories.

\section{Maps}

Geologic Quadrangle Maps (GQ's) are multicolor geologic maps on topographic bases in 7.5 or 15 -minute quadrangle formats (scales mainly 1:24,000 or 1:62,500) showing bedrock, surficial, or engineering geology. Maps generally include brief texts; some maps include structure and columnar sections only.

Geophysical Investigations Maps (GP's) are on topographic or planimetric bases at various scales. They show results of geophysical investigations using gravity, magnetic, seismic, or radioactivity surveys, which provide data on subsurface structures that are of economic or geologic significance.
Miscellaneous Investigations Series Maps or Geologic Investigations Series (I's) are on planimetric or topographic bases at various scales; they present a wide variety of format and subject matter. The series also includes 7.5-minute quadrangle photogeologic maps on planimetric bases and planetary maps.

\section{Information Periodicals}

Metal Industry Indicators (MII's) is a free monthly newsletter that analyzes and forecasts the economic health of five metal industries with composite leading and coincident indexes: primary metals, steel, copper, primary and secondary aluminum, and aluminum mill products.

Mineral Industry Surveys (MIS's) are free periodic statistical and economic reports designed to provide timely statistical data on production, distribution, stocks, and consumption of significant mineral commodities. The surveys are issued monthly, quarterly, annually, or at other regular intervals, depending on the need for current data. The MIS's are published by commodity as well as by State. A series of international MIS's is also available.

Published on an annual basis, Mineral Commodity Summaries is the earliest Government publication to furnish estimates covering nonlife mineral industry data. Data sheets contain information on the domestic industry structure, Government programs, tariffs, and 5-year salient statistics for more than 90 individual minerals and materials.

The Minerals Yearbook discusses the performance of the worldwide minerals and materials industry during a calendar year, and it provides background information to assist in interpreting that performance. The Minerals Yearbook consists of three volumes. Volume I, Metals and Minerals, contains chapters about virtually all metallic and industrial mineral commodities important to the United States economy. Volume II, Area Reports: Domestic, contains a chapter on the minerals industry of each of the 50 States and Puerto Rico and the Administered Islands. Volume III, Area Reports: International, is published as four separate reports. These reports collectively contain the latest available mineral data on more than 190 foreign countries and discuss the importance of minerals to the economies of these nations and the United States.

\section{Permanent Catalogs}

"Publications of the U.S. Geological Survey, 1879-1961" and "Publications of the U.S. Geological Survey, 19621970" are available in paperback book form and as a set of microfiche.

"Publications of the U.S. Geological Survey, 1971-1981" is available in paperback book form (two volumes, publications listing and index) and as a set of microfiche.

Annual supplements for 1982, 1983, 1984, 1985, 1986, and subsequent years are available in paperback book form. 



\section{avis:}

s.s.

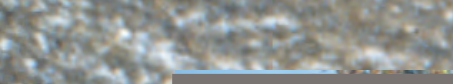

the bers

Xit.

2ir $x^{2} \times 3 \times 3 y$

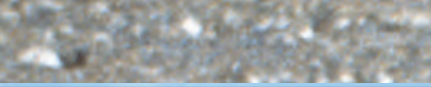

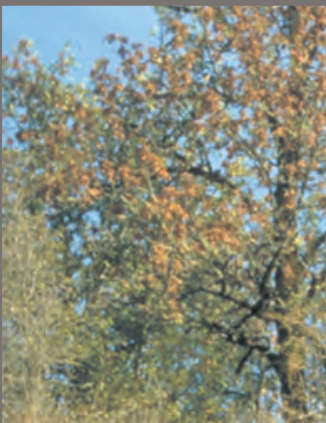

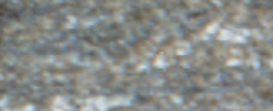

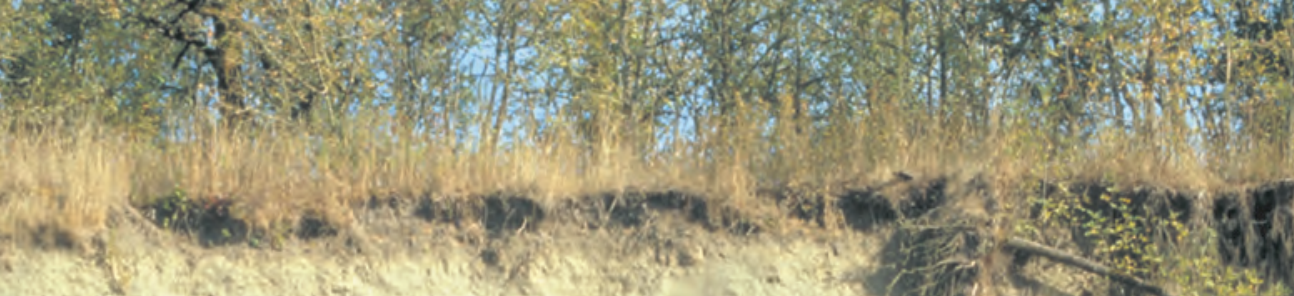

9. (1) 11,1

tose

(5) 2402

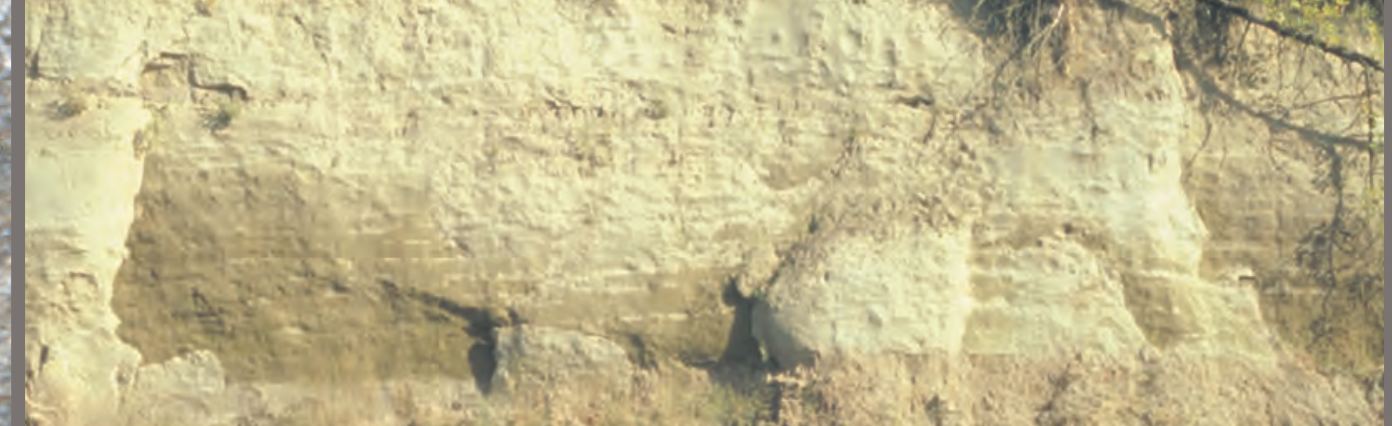

$x_{3}=0$

ron.ts

(

ist in

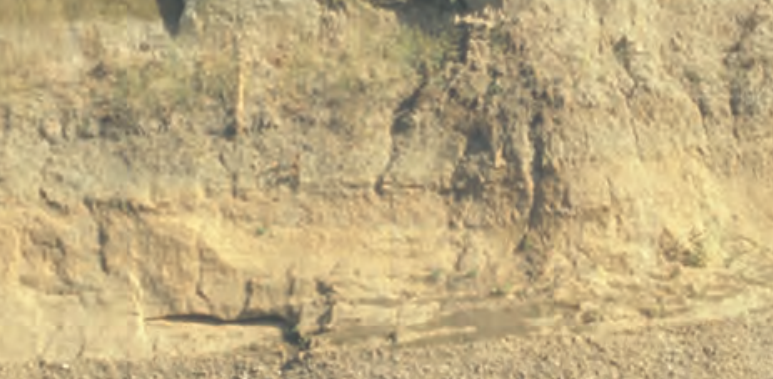

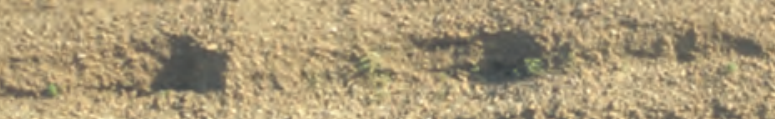

The

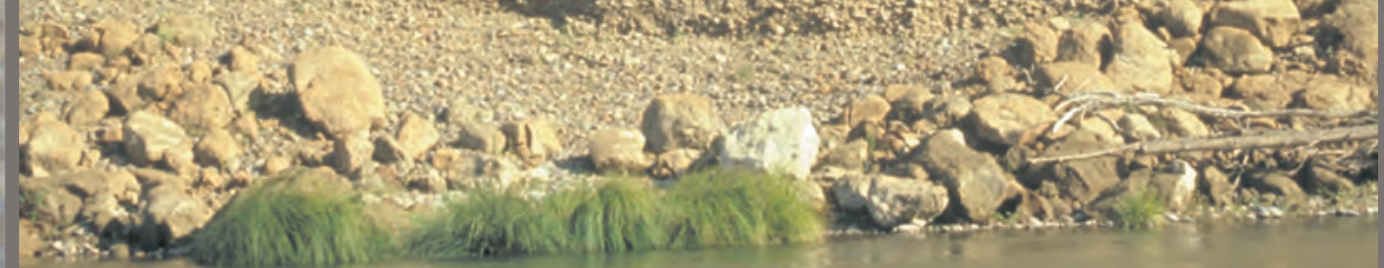

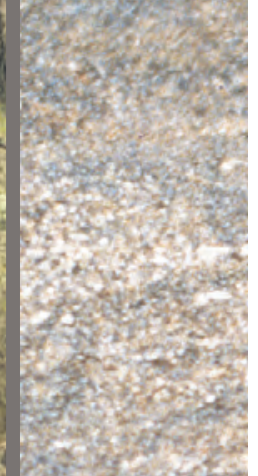

